\title{
Application of Alginate Hydrogels for Next-Generation Articular Cartilage Regeneration
}

\author{
Wei Liu (1), Henning Madry (1) and Magali Cucchiarini *(])
}

Citation: Liu, W.; Madry, H.; Cucchiarini, M. Application of Alginate Hydrogels for Next-Generation Articular Cartilage Regeneration. Int. J. Mol. Sci. 2022, 23, 1147. https://doi.org/10.3390/ ijms23031147

Academic Editor: Elizabeth W. Bradley

Received: 22 December 2021

Accepted: 18 January 2022

Published: 20 January 2022

Publisher's Note: MDPI stays neutral with regard to jurisdictional claims in published maps and institutional affiliations.

Copyright: (C) 2022 by the authors. Licensee MDPI, Basel, Switzerland. This article is an open access article distributed under the terms and conditions of the Creative Commons Attribution (CC BY) license (https:// creativecommons.org/licenses/by/ $4.0 /)$.
Center of Experimental Orthopaedics, Saarland University Medical Center, Kirrbergerstr. Bldg 37, D-66421 Homburg (Saar), Germany; dr.wei.liu@hotmail.com (W.L.); henning.madry@uks.eu (H.M.)

* Correspondence: magali.madry@uks.eu; Tel.: +49-6841-1624-987

\begin{abstract}
The articular cartilage has insufficient intrinsic healing abilities, and articular cartilage injuries often progress to osteoarthritis. Alginate-based scaffolds are attractive biomaterials for cartilage repair and regeneration, allowing for the delivery of cells and therapeutic drugs and gene sequences. In light of the heterogeneity of findings reporting the benefits of using alginate for cartilage regeneration, a better understanding of alginate-based systems is needed in order to improve the approaches aiming to enhance cartilage regeneration with this compound. This review provides an in-depth evaluation of the literature, focusing on the manipulation of alginate as a tool to support the processes involved in cartilage healing in order to demonstrate how such a material, used as a direct compound or combined with cell and gene therapy and with scaffold-guided gene transfer procedures, may assist cartilage regeneration in an optimal manner for future applications in patients.
\end{abstract}

Keywords: alginate; hydrogel; cell therapy; gene therapy; scaffold-guided gene transfer; cartilage regeneration

\section{Introduction}

The articular cartilage, the gliding avascular tissue covering the extremities of articulating bones in synovial joints, is a specialized tissue essentially composed of chondrocytes, producing a dense extracellular matrix (ECM) in a highly defined territorial matrix microstructure and zonal cartilage macrostructure. Articular cartilage lesions that occur during trauma, with the degradation of the ECM together with chondrocyte alterations, are common clinical problems that remain challenging, as none of the current conservative and surgical treatments reliably restore the original hyaline cartilage tissue with complete structural and functional integrity in sites of injury [1]. Reparative processes are also impeded by the improper intrinsic ability of the articular cartilage to self-heal, with its potentially unstable chondrocyte phenotype [2,3], showing the urgent need for more effective therapeutic options capable of enhancing the processes of cartilage regeneration.

In this regard, alginate, a compound based on a polysaccharide from brown algae, displays several advantageous features that make it a particularly well-suited material in tissue engineering approaches for cartilage regeneration. Alginate is a biocompatible component with a high water content and good porosity and with tunable viscosity, broadly reported for its ability to easily form hydrogels that can be used as scaffolds to load cells and drugs [4]. Extensive work has described using alginate-based hydrogels as therapeutic platforms for applications in cartilage regeneration, with such systems based on continuous progress and advances, leading to emerging systems that can be adapted to fit sites of cartilage injury using reparative cells, external stimuli, and a variety of modifications of the alginate systems (Figure 1). 


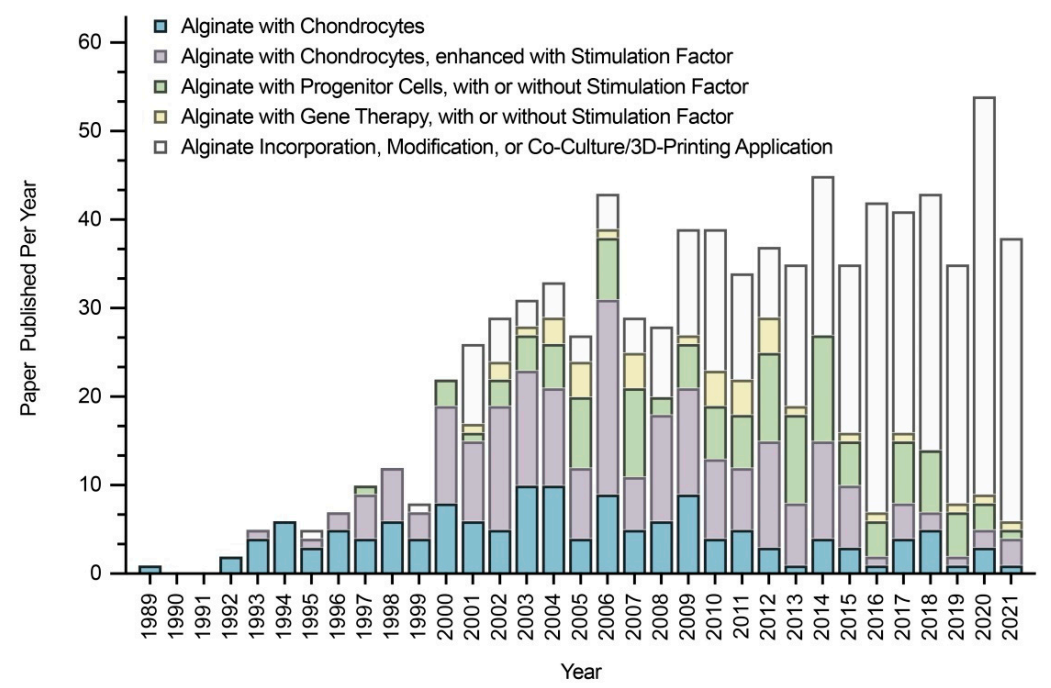

Figure 1. Research progress on alginate for cartilage regeneration (created with Prism).

The goal of this work is to present a comprehensive appraisal of the potential applications of alginate for cartilage regeneration, covering experimental and preclinical data, in vitro and in vivo, and the currently available clinical protocols. A further goal is to discuss the benefits of each approach developed, especially those based on the incremental use of chondro-reparative cells (chondrocytes, progenitor cells) and biological/physicochemical stimuli (recombinant factors, mechanical compression, oxygen tension, osmotic pressure, ultrasounds), as well as their specific limitations. Emerging systems to tackle these limitations are also introduced and discussed, with a special focus on using alginate in combination with gene therapy and with other compounds or modifications that may altogether lead to next-generation, better-adapted alginate systems for effective translational applications in cartilage regeneration to treat patients in the future.

\section{Articular Cartilage: Functions, Structure, Injuries, and Current Options \\ 2.1. Functions and Structure of Articular Cartilage}

The articular cartilage is the gliding tissue in the joints [5] that supports load transmission and translation, shock absorption, and friction reduction in synovial articulations [6,7]. The biological structure of the articular cartilage is critical to its functions [8].

\subsubsection{Function and Microstructure}

The articular cartilage is composed of chondrocytes that produce and surround themselves with a highly hydrated ECM $[5,9,10]$. The chondrocytes represent the main cell type in the articular cartilage that also includes a population of stem cells [11] or progenitor cells [12-14]. Altogether, these cells contribute to only 5\% of the total cartilage volume [5]. At the adult age, these cells rarely divide, but they maintain an ability to produce and retain this ECM after skeletal maturity [15]. The ECM is composed of a pericellular, territorial, and interterritorial matrix [16,17]. The extensively studied territorial matrix can be considered to be a chondron-surrounding structure consisting of a high concentration of soluble proteoglycans (PGs) with rapid turnover, embedded in a dense meshwork of fibrous proteins with low turnover [5,18-21]. PGs used as a cell cushion consist of a protein core surrounded by long chains of starch-like molecules called glycosaminoglycans (GAGs) [22] which can be classified as large, predominant PGs, such as aggrecan, and as small, minor PGs, such as decorin, biglycan, asporin, lumican, and fibromodulin [18,23,24]. GAGs include hyaluronic acid (HA), dermatan sulfate, chondroitin sulfate, heparan sulfate, and keratan sulfate [22], while the major GAGs attached to the core protein include chondroitin-4/6-sulfate and keratan sulfate [22]. Additionally, non-HA GAGs interacting with HA leads to PGs forming large, multi-molecular aggregates (aggregating PGs) [25]. Aggrecan, also known as the cartilage-specific proteoglycan core protein (CSPCP), or chondroitin-1-sulfate, is a protein 
encoded by the aggrecan gene in humans [26], and always represents the predominant population of the PGs synthesized [22,27]. Its size varies depending on the age of the cartilage from which the cells are derived [27]. Small PGs are represented by decorin and biglycan, with leucine-rich regions in their core protein and chondroitin sulfate or dermatan sulfate chains, respectively [28], and interact with type-II collagen [18], taking $1-2 \%$ of the total mass of the PGs as essential components of the normal mature articular cartilage [29]. The fibrous proteins used to support cells are composed of insoluble structural proteins, providing strength and resilience (type-II collagen and other collagens) and elastin and soluble specialized proteins that bind PGs and collagen fibers to receptors on the cell surface (fibronectin, laminin) $[5,18,20,21]$. Type-II collagen is the basis for the hyaline cartilage formed by the homotrimers of type-II collagen alpha 1 chains, representing up to $50 \%$ of all proteins and $85-90 \%$ of collagens in the tissue [20,23,28,30-37]. Other collagens include smaller amounts of type-VI [23,30-33,37], -IX [20,23,28,30-37], -XI [20,23,28,30-37], and -XIV collagen [30-32,37], and some type-I/-X collagen [38], which play important roles in the formation and stability of fibrils in the mature articular cartilage [39]. Compared with the territorial matrix, a variety of matrix molecules, such as aggrecan monomers and small aggregates [40,41], type-VI [42,43] and -IX collagen [44,45], hyaluronan [41,46], biglycan [47], and perlecan [48], can be found either exclusively or at higher concentration in the pericellular matrix. Interactions between the molecular constituents of the ECM contribute to the distinct macrostructure of the ECM. Large quantities of water are confined by PGs, contributing to up to $70-80 \%$ of the cartilage wet weight [31], opposing the deformation caused by compressive loading and tensile loading in the joint.

\subsubsection{Function and Macrostructure}

The articular cartilage is subdivided into the superficial, middle, and deep zones $[5,9,10]$. The superficial, tangential zone is composed of ellipsoidal cells aligned parallel to the surface [5]. In this zone, the chondrocytes have the smallest size [15] and the cell density is the most elevated [15,49-51]. The superficial zone represents approximately $10 \%$ of the articular cartilage volume [52], with the lowest biosynthetic activity [51] and the highest amounts of small PG [53,54] and type-II [55] and -I collagen [56] deposition. The deposition of small PGs and type-II collagen decreases with the increase in the distance from the superficial zone [38], while clusterin [57,58] and the superficial zone protein (SZP) [59-61] are found exclusively in this zone. Collagen fibers are orientated at high densities in bundles parallel to the articulating surface, along with the cells, giving the superficial zone the highest ability of tensile stiffness and strength $[62,63]$. The middle zone is composed of randomly distributed spherical chondrocytes within a matrix, with collagen fibrils arranged in an oblique orientation to the surface [5], displaying a middle size at the lowest cell density [15]. This zone approximately accounts for $60-70 \%$ of the articular cartilage volume [52], with a high deposition of HA [64], dermatan sulfate [64], and cartilage intermediate layer protein [65]. The deep zone contains the largest cells [15], which are arranged in columns aligned perpendicular to the surface [5] with a middle-range cell density [15]. This zone almost occupies $10-15 \%$ of the articular cartilage volume [52], with the highest amounts of large PG [55], type- $X$ collagen [55], cartilage oligomeric protein (COMP) [66], and keratan sulfate [64,67] deposition. Chondroitin sulfate has been reported to have either the highest deposition in the deep [64] or in the middle zone [67], depending on the methods of evaluation and on the variability of the samples tested. Large PGs are orientated at a high density in vertical columns perpendicular to the articulating surface along with the cells, allowing the deep zone to have a higher ability of compressive and resilience [15]. Differences in cell morphology, cell densities, cell metabolism, and matrix biochemical composition in each zone are the reasons of the different functions in the zonal articular cartilage [24]. The assembly of biomolecules determines the functionally defined cartilage, supporting its ability to transmit load, absorb shock, and reduce friction [19], while alterations of any of its components may decrease its ability to withstand loads placed across it [8]. 


\subsubsection{Special Features}

The special biological features of the articular cartilage include its low cellularity, low proliferation, low cell migration, low vascularization, and low nutrition and waste diffusion, which together explain why the articular cartilage is intrinsically unable to readily regenerate itself [68-78]. As a result, chondrocytes are difficult to obtain in large quantities, for instance, in implantation protocols in cartilage regeneration [27,36,79-81]. In particular, the culture and expansion of chondrocytes in vitro remains problematic [72,82], since these cells differentiate into different phenotypes during expansion culture [83,84], including via transdifferentiation (hypertrophy/osteoblast expression) $[85,86]$ and dedifferentiation (fibroblast expression) $[87,88]$ relative to the normal differentiation state (original expression). Normally differentiated chondrocytes are found at the early stages of the monolayer culture [89], with a main deposition of type-II collagen [90,91], aggregating PGs [92], and a zonal characteristic protein (such as SZP) [93], accompanied by low levels of alkaline phosphatase activity [83]. Transdifferentiation chondrocytes are detected in high-density monolayer or organoid cultures [89], with a main deposition of type-X collagen [35,83,94], non-aggregating PGs [25,83], and osteopontin [35,83,94], accompanied by high levels of alkaline phosphatase activity [83,95], matrix vesicle formation [83], and endochondral ossification [94], mostly occurring at a fetal stage [94]. Dedifferentiating chondrocytes are found in low-density monolayer cultures (majority) $[35,96,97]$, with a main deposition of type-I/-III/$\mathrm{V}$ collagen $[21,34,98]$ and of non-aggregating PGs $[25,89]$, accompanied by an increase in CD44 fragmentation [99] and a decrease in the expression of type-II transforming growth factor beta (TGF- $\beta$ ) receptor (T $\beta$ RII) and in the TGF- $\beta$ response [100], mostly occurring at an adult stage $[33,36,94]$. The chondrocyte phenotype is affected by factors such as the cell adhesion status and the cell shape, and it differs in monolayer and three-dimensional (3D) culture systems [25], indicating that geometric entrapment is essential for the maintenance of the chondrocyte phenotype in vitro [101]. Suspension with gel seems to be an excellent method of geometric embedment for chondrocytes [80,83], likely promoting the retention of the original phenotype $[102,103]$ that is required for articular cartilage regeneration.

\subsection{Articular Cartilage Injuries}

Articular cartilage injuries resulting from trauma or other causes affect more than $60 \%$ of examined patients [104], and may further deteriorate if left untreated [105,106]. From a macroscopic perspective (morphology), changes affecting the articular cartilage include extended matrix discontinuities, clefts, and erosions, while from a microstructural point of view (pathology), they include chondrocyte hypertrophy, apoptosis and necrosis, and a loss of PGs [5], which gradually and eventually leads to the formation of large cartilage defects, classified as either chondral defects restricted to the articular cartilage or osteochondral defects that further disrupt the underlying subchondral bone $[107,108]$. The injured articular cartilage has a limited intrinsic capacity for self-healing and the chondrocytes adjacent to the lesions do not substantially contribute to the reconstruction of the cartilage [108].

\subsection{Current Clinical Options to Enhance Articular Cartilage Regeneration}

Clinical strategies to manage articular cartilage injuries include conservative treatments to reduce pain and/or maintain mobility and surgical treatments to replace the damaged (osteo)chondral tissue and/or to induce repair [108]. Conservative treatments include non-pharmacological interventions (physical therapy) and pharmacological treatments (oral, topical, and intra-articular applications), both of which have had mixed success [5,108]. Surgical interventions include marrow stimulation (microfracture), autologous chondrocyte implantation $(\mathrm{ACI})$, and the transplantation of autologous or allogeneic osteochondral grafts [108]. Microfracture is an adapted procedure to repair small (but not large) defects, mostly in young patients $(<40)$ and especially to treat femoral condyles rather than other parts of the knee joint [109]. ACI avoids immune rejection, but needs intensive surgery to acquire chondrocytes [109]. Osteochondral graft transplantation, using non-weight-bearing articular surfaces from the patient, is relatively simple to per- 
form, and also avoids immune rejection, but it is also best-suited for small defects [109]. However, none of these options lead to full cartilage regeneration in the sites of lesions. Microfracture may lead to the development of a fibrocartilaginous repair tissue that lacks the original hyaline structure of the native cartilage and which is unable to withstand mechanical loading $[30,37,108,110,111]$. ACI may be complicated by phenotype changes to the chondrocytes (hypertrophy), insufficient regenerative cartilage, and disturbed fusion $[30,37,108,110,111]$. Else, osteochondral graft transplantation may be impeded by disease transmission, graft failure, donor site morbidity, donor-to-recipient site incongruity, and hemarthrosis $[30,37,108,110,111]$. Overall, such outcomes show the critical need for improved strategies for cartilage regeneration. In this regard, the use of alginate hydrogels may represent an adapted platform for therapy, as they are based on a biocompatible, easy-to-handle material that can accommodate cells (and even tissues), biological stimuli (recombinant factors and even genes), and which are tunable to fit in all types of cartilage lesions (regardless of their size and location and of the patient's age). They are being approved for use in trials, as described in detail in the following sections.

\section{Alginate: Characteristics and Properties for Hydrogel Preparation}

\subsection{Basic Knowledge}

Alginates are unbranched linear copolymers composed of 1,4-linked $\beta$-D-mannuronic acid (M) and 1,4-linked $\alpha$-L-guluronic acid (G), with regions exclusively composed of one unit or of the other (consecutive M block/residues, consecutive G block/residues), or with regions where the monomers approximate an alternating sequence (alternating MG block/residues) (Figure 2) [112,113].

a

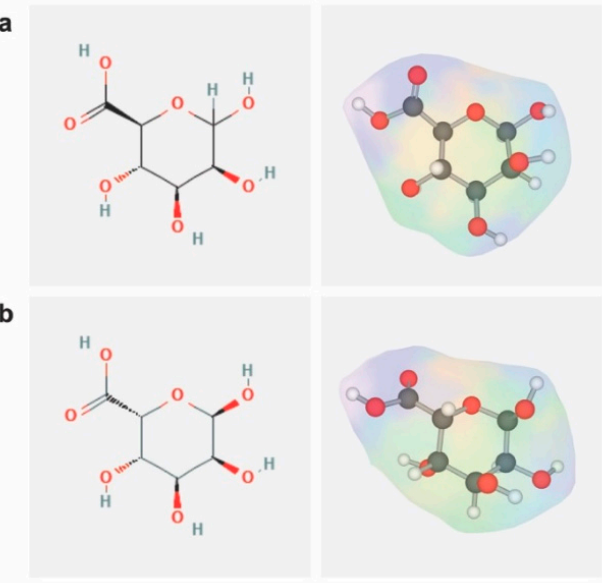

Figure 2. Structure of 1,4-linked $\beta$-D-mannuronic acid and 1,4 linked $\alpha$-L-guluronic acid. The two-dimensional structures of (a) 1,4-linked $\beta$-D-mannuronic acid (CID: 439630) and (b) 1,4 linked $\alpha$ L-guluronic acid (CID: 446401) were obtained from PubChem and their three-dimensional structures were drawn with LiteMol Viewer (1.6.5).

Typically, alginate can be isolated from brown algae [114,115], which belong to Phaeophyceae (seaweeds) [112,116] or are extracted from bacteria, such as Pseudomonas or Azotobacter [117]. Alginate can be of nonbiomedical- or biomedical-grade quality (most employed) [103], of low (commonly used), medium, or high viscosity [103], and of low or high molecular weight (also termed polymer chain length) [112]. Alginate is hydrophilic, water soluble, and thickening in neutral conditions, and can form gel (hydrogel) when present in polyvalent cations $[118,119]$.

\subsection{Physicochemical Properties}

\subsubsection{Gel Formation}

Gelation occurs when polyvalent cations cooperatively interact with blocks of M/G monomers to form ionic bridges $[112,117,120]$, followed by the formation of the 3D gel 
network via Van der Waals forces between alginate segments [121,122]. Cations that crosslink with alginate hydrogels include divalent cations $\left(\mathrm{Ca}^{2+}, \mathrm{Ba}^{2+}, \mathrm{Sr}^{2+}, \mathrm{Cd}^{2+}, \mathrm{Co}^{2+}\right.$, $\mathrm{Cu}^{2+}, \mathrm{Mn}^{2+}, \mathrm{Ni}^{2+}, \mathrm{Pb}^{2+}$, and $\left.\mathrm{Zn}^{2+}\right)[82,117,123-130]$, trivalent cations $\left(\mathrm{La}^{3+}, \mathrm{Pr}^{3+}, \mathrm{Nd}^{3+}\right.$, $\mathrm{Eu}^{3+}$, and $\left.\mathrm{Tb}^{3+}\right)$ [124], or multiple cations $\left(\mathrm{Co}^{2+}\right.$ and $\left.\mathrm{Ca}^{2+}\right)$ [131], but neither $\mathrm{Mg}^{2+}$ nor monovalent cations $[123,124,132]$. During crosslinking, divalent metal ions exhibit a preference for GG blocks and lead to an increase in the extent of binding when increasing the ionic radius, while trivalent metal ions display a preference for GG blocks and lead to an increase in the extent of binding for both GG and MM blocks when increasing the charge density [124]. The contrast in the modes of interaction of divalent and trivalent cations with alginic acid may be related to differences in the coordination number and/or to hydration remaining in the inner sphere of ions [124].

The physicochemical and bioscaffolding properties of alginate have been reported to depend on the $\mathrm{M} / \mathrm{G}$ ratio $[133,134]$ and on the concentration of the alginate and gelling solutions $\left(\mathrm{Ca}^{2+}\right)[120]$.

First, $\mathrm{M} / \mathrm{G}$ ratios differ according to the source of raw material used in alginate manufacture $[133,134]$, with alginates with a high $M / G$ ratio primarily derived from Macrocystis pyrifera [112]/Durvillea potarum [135] and alginates with a low M/G ratio from Laminaria hyperborean [112]. M/G ratios also have an impact on the biological activities of the chondrocytes at encapsulation, including cell adhesion, colonization, migration, nutrition diffusion, and proliferation [125]. Alginates with a low $M / G$ ratio retain greater tensile strength [125,134], offering a substrate against which traction can be exerted and, therefore, which aids cell adhesion, colonization, and subsequent migration [125]. Additionally, the diffusion of large molecules is impeded by alginate, an effect that is less evident for alginates with a low $M / G$ ratio [136]. In this regard, alginates with a low $M / G$ ratio allow for optimal cell proliferation [103]. The mechanical properties, including dynamic modulus, peak strain, and peak stress, are improved when using alginates with a low $M / G$ ratio, while alginates with a high $M / G$ ratio yield weaker and more elastic gels $[112,129,137]$.

Second, alginate concentrations of $0.5-4 \%(w / v)$ and $\mathrm{Ca}^{2+}$ concentrations of $15-144 \mathrm{mM}$ have been reported to be suitable for cartilage regeneration [138,139]. A gel with optimal handling characteristics can be obtained with alginate at $1-1.5 \%(w / v)$ and $\mathrm{Ca}^{2+}$ at $30-50 \mathrm{mM}$ [120]. Most research was developed with alginate at $1.2 \%(w / v)$ and $\mathrm{Ca}^{2+}$ at $102 \mathrm{mM}$ [68,140-149]. The adhesion, colonization, and migration of embedded cells are enhanced when increasing the concentration of alginate $[136,150]$ or of $\mathrm{Ca}^{2+}[122,139]$, while the diffusion of large molecules becomes gradually impeded [136,151]. The effects of the alginate and $\mathrm{Ca}^{2+}$ concentrations occur in a dose-dependent manner [150,152]. Of note, the stiffness [136] and compressive modulus [150] increase with the increasing alginate concentration, while the shear moduli increase with higher $\mathrm{Ca}^{2+}$ concentrations [139]. At low $\mathrm{Ca}^{2+}$ concentrations, temporary gels can be obtained as highly viscose solutions, while stable gelation may result from permanent associations of crosslinking structures at high $\mathrm{Ca}^{2+}$ levels [122]. Specially, $\mathrm{Ca}^{2+}$ concentrations of 36, 72, and $144 \mathrm{mM}$, using alginate at $2 \%$, has no effect on gel degradation [139].

\subsubsection{Gel Dissolution}

Alginate gels dissolve upon the loss of polyvalent cations, releasing high and low molecular weight alginate strands [153] via spontaneous or induced dissolution.

Spontaneous dissolution occurs upon the substitution of crosslinking polyvalent ions with monovalent ions, such as $\mathrm{Na}^{+}$[154]. Large differences are reported in dissolving times [155-157], possibly as a result of differences in experimental models, implant volumes, material forms, and external environments [125].

Induced dissolution occurs via the chelation of crosslinking polyvalent ions with a dissolving buffer $[39,89,112,158]$, including ethylenediaminetetraacetic acid (EDTA) $(50 \mathrm{mM})$ [81,158], citrate (55 $\mathrm{mM}$ sodium citrate in $0.15 \mathrm{M} \mathrm{NaCl})[97,158]$, and phosphate solution [83,89]. Typically, $50 \mathrm{mM}$ EDTA is more cytotoxic than $55 \mathrm{mM}$ citrate, and $55 \mathrm{mM}$ citrate is more cytotoxic than phosphate-buffered saline (PBS) when dissolved for the same 
period of time [159]. One of the major advantages of alginate is that the gel where the cells are entrapped can be dissolved with chelation [23,27].

\subsubsection{Gel Characteristics}

Alginate gels can be prepared in a microscopically homogeneous manner [160], with a compression modulus from 1 to $1000 \mathrm{kPa}$ [161] and a shear modulus from 0.02 to $40 \mathrm{kPa}$ [161]. Such gels exhibit $\mathrm{pH}$-responsive properties, with higher swelling ratios when increasing the $\mathrm{pH}$ values due to the chain expansion from the presence of ionic carboxylate groups on the backbone [117].

\subsubsection{Alginate Degradation}

The shortcomings of alginate include a lack of biodegradability $[153,162]$ due to its very slow degradation rate and an uncontrollable degradation pattern, resulting in the release of high molecular weight strands that may be difficult to clear from the body $[117,119,153]$.

A partially oxidized alginate (periodate oxidation) may promote its hydrolysis ( $9 \mathrm{ds}$ in PBS solution) with the cleavage of carbon-carbon bonds of cis-diol groups in uronate residues and an alteration of the chain conformation when crosslinking with calcium ions [153].

\subsubsection{Other Features}

As a result of negative charges in alginate, the extracellular environment where cells may be maintained mirrors the cartilage ECM more closely than any other culture system [27].

As a natural polysaccharide, alginate exhibits a $\mathrm{pH}$-dependent anionic nature and an ability to interact with cationic polyelectrolytes and PGs [117], making it a convenient system to entrap cells for in vitro growth $[22,83]$.

In addition, while alginate may have different endotoxin contents depending on its level of purity, its relative stability with regard to biocompatibility has been demonstrated, supporting its adapted use as a biomaterial $[103,163]$.

\section{Alginate and Chondrocytes for Articular Cartilage Regeneration}

Chondrocytes have been originally manipulated as a natural source of cells for entrapment in alginate for applications that aim to enhance the processes of cartilage regeneration.

\subsection{Gelation}

The process of alginate gelation with chondrocytes can be classified under cell encapsulation/adhesion or under cation diffusion/dissociation (Figure 3).

In the cell encapsulation and cation diffusion approach, the cell suspension is mixed with the alginate and gelling solutions using a syringe (this is the most used technique) $[140,144]$, tips, or a Transwell insert $[138,164,165]$.

In the cell encapsulation and cation dissociation approach, the cell suspension and alginate solution are mixed with a special gelling solution (e.g., $\mathrm{CaCO}_{3}$ ) where ions are gradually ionized [139].

In the cell adhesion and cation diffusion approach, the alginate and gelling solutions are mixed using microfluidics [166-168] or freeze-dried [117,169], followed by the seeding of the cell suspension.

a

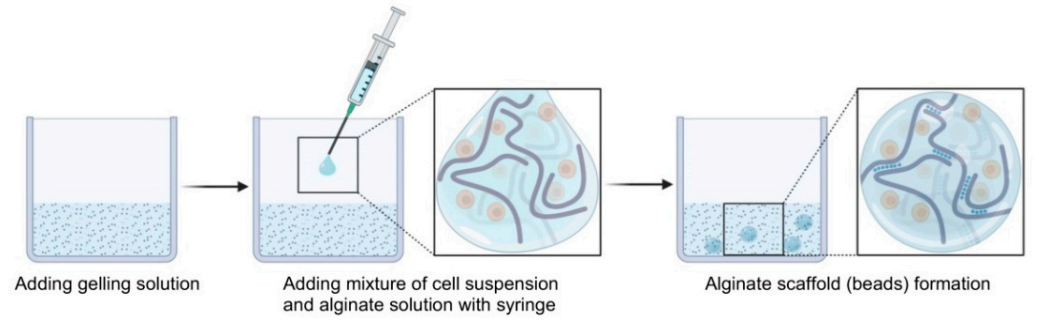

Figure 3. Cont. 

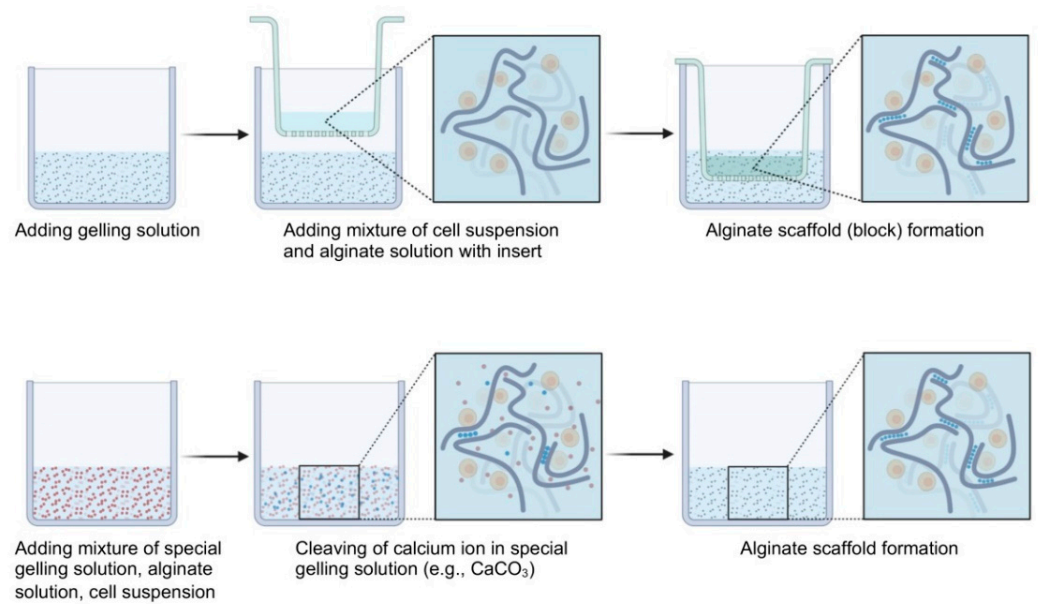

d
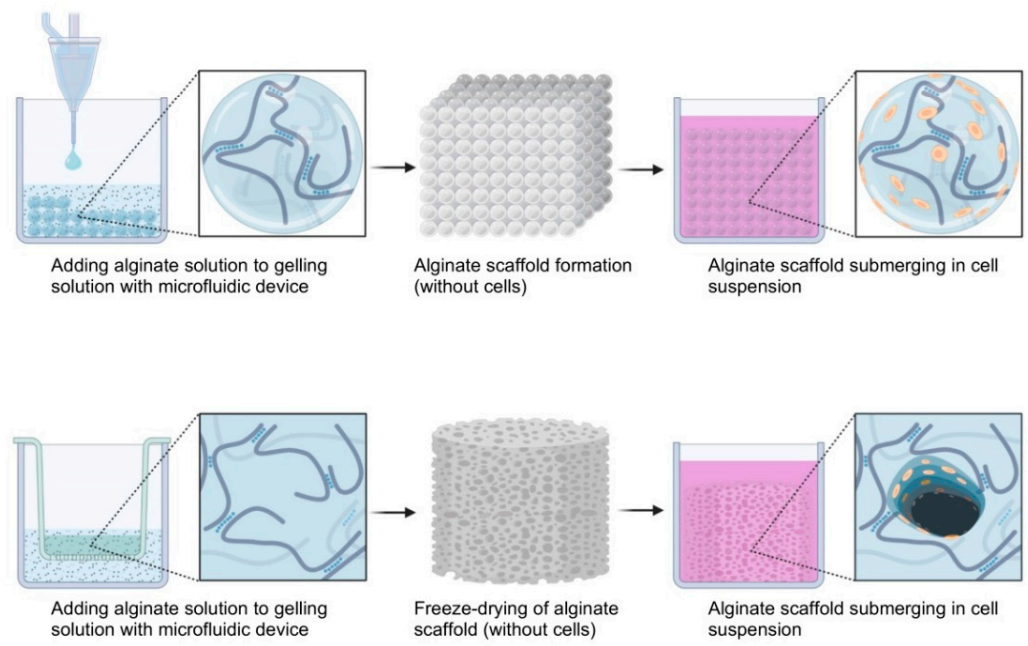

Figure 3. Fabrication of a cell-alginate hydrogel. (a-c) Cell encapsulation, (d,e) cell adhesion, $(\mathbf{a}, \mathbf{b}, \mathbf{d}, \mathbf{e})$ cation diffusion, and (c) cation dissociation (created with BioRender.com).

The diffusion system is always associated with non-uniform gelation. The preparation of an alginate gel is a rapid process that limits the diffusion of gelling ions into the gel network so the heterogeneity can be reduced when a microstructure is used [170]. The rapid gelling process also limits the diffusion of gelling ions at different distances; thus, the heterogeneity can also be decreased when the sphere structure is employed [170]. Therefore, microbeads are mostly used in the literature $[68,140,141]$. Additionally, the diffusion system is usually associated with microchannel formation. Microchannels are formed by blocking the rapid diffusion of ions from the gelling solution into the boundary of the alginate solution and extending inward from the cells at the surface of the gel [160]. Microchannels are numerous when both the alginate and the gelling solutions lack $\mathrm{Na}^{+}$ions or other monovalent cations [160]. Therefore, alginate is usually dissolved in $\mathrm{NaCl}(0.15 \mathrm{M})$ [145,171,172]. Furthermore, the dissociation system is often associated with ion-supersaturated gelation or semi-gelation. Alginate gels based on internal gelling have a more defined and limited supply of gelling ions compared with diffusion systems where ions are allowed to diffuse in the alginate solution to produce an ion-saturated gel [173]. In the presence of excessive amounts of gelling ions, the cell viability decreases, as gelling ions are cytotoxic before crosslinking and, conversely, semi-gelation occurs well with uncertain physiochemical and biological properties [159], making it difficult overall to obtain suitable conditions.

Key points to consider at gelation include the source of cells, the cell seeding density, and the environment and supporting medium. The chondrocytes used in cartilage research are various and include human $[97,140]$ or non-human [140,167] cells, articular [171,174] or 
non-articular $[95,175]$ chondrocytes, normal $[27,174]$ or OA $[176,177]$ cells, and superficial, middle, or deep zone [38] chondrocytes.

The diversity of the cell source employed may lead to different biomechanical and physiological results when applied for cartilage regeneration purposes. At various cell seeding densities, the ability of cell proliferation and/or of ECM deposition may also be affected [112], with a variability in the PG or collagen deposition $[164,178]$ when modifying (increasing) the cell density. When increasing the cell seeding density at a prolonged culture time, the mechanical property (equilibrium tensile modulus) of the alginate gel increases [164] and the alginate beads have a tendency to crack and a great propensity to break apart [112].

Regarding the environment, decreases in the concentration of oxygen and of other nutrients in the center of the alginate impact the metabolism (reduction). Consequently, the rate of accumulation of ECM is limited by the rate of ECM production per cell and by the cell density that can be maintained in a viable state [178]. The administration of fetal bovine serum (FBS) results in the increased synthesis of ECM (PGs) per cell, but not in increased proliferation rates compared with serum-free conditions at short-term periods (equine and porcine chondrocytes) [112]. The application of human serum results in the increased deposition of ECM (PGs and type-II collagen) per cell but also in increased proliferation rates compared with FBS controls (human nasal septal chondrocytes from a young donor) [179].

Most studies have been performed using a $\mathrm{Ca}^{2+}$ concentration at $1.8 \mathrm{mM}$ in culture medium after gelation, while the $\mathrm{Ca}^{2+}$ levels in the synovial fluid of normal human knee joints are $4 \mathrm{mM}$ or even higher [158]. With a high-level concentration of $\mathrm{Ca}^{2+}(4-8 \mathrm{mM})$, the dynamic shear modulus, equilibrium shear modulus, and phase shift angle increase, but neither the equilibrium compressive modulus nor the total ECM (PGs and collagen) deposition increases [158].

Furthermore, a four-fold increase in glucose concentrations enhances the final mass of alginate by $10 \%$ and the deposition of PGs by $73 \%(5.1-20.4 \mathrm{mM})$, while a four-fold increase in the medium volume enhances the final mass of alginate by $44 \%$ and the deposition of PGs by $207 \%\left(0.4-1.6 \mathrm{~mL} / 10^{-6}\right.$ cells) [180].

\subsection{In Vitro Studies}

\subsubsection{Cell Morphology}

Chondrocytes from different sources maintain a characteristically differentiated morphology in alginate throughout in vitro culture conditions [22,23,34,83,114]. After one day, the cells develop a spherical appearance and are irregularly scattered in the gels [83].

The cell cytoplasm contains a scarce amount of cisternae of the granular endoplasmic reticulum, few mitochondria, free ribosomes, non-prominent Golgi apparatus, abundant glycogen granules, and several cytoplasmic vacuoles with an amorphous or irregular reticular substance [83]. After 14 ds [83], 30 ds [22], and $8 \mathrm{mo}$ [23], the cells exhibit cartilagelike [181,182], zone-associated specific shapes (surface to depth: flattened/ellipsoidal to spherical) [23,39] and form aggregates (normally two to ten cells/cluster, rarely 20 or more) [83]. The cytoplasm of the cells contain one or more prominent nuclei [22], numerous mitochondria and polyribosomes, developed granular endoplasmic reticulum and polyribosomes, and Golgi area, the vacuoles of which contain granules and filaments, with an overall increase in the cell volume [83].

\subsubsection{Cell Viability}

When stored at $4{ }^{\circ} \mathrm{C}$ for $30 \mathrm{ds}$, the viability of the chondrocytes embedded in alginate does not significantly decrease over the culture period $(67 \%$ before storage and $60 \%$ after storage using high viscosity alginate) [183].

When maintained in culture at $37^{\circ} \mathrm{C}$ for $30 \mathrm{ds}$, the viability of chondrocytes in alginate increases during the period of culture ( $85 \%$ by digestion from cartilage and $95 \%$ upon alginate dissolution) [162].

When maintained for $3 \mathrm{mo}$ at $37^{\circ} \mathrm{C}$, the viability of chondrocytes in alginate is stable and of at least $80 \%$ throughout the period of culture [184]. 
There is no significant difference in the viability of chondrocytes kept in a medium with or without serum [112] nor between chondrocytes in monolayer and in alginate cultures [167]. Nevertheless, there is a significant difference in the viability of cells from normal versus OA cartilage [185] and using high [183] versus low viscosity alginate [162].

The viability of chondrocytes also depends on nutrient supply and oxygen, and on the presence of wastes that may diffuse throughout the alginate [137], while normal cell metabolism is not negatively affected by the conditions of encapsulation in alginate.

\subsubsection{Cell Proliferation}

Significant differences in the levels of cell proliferation exist depending on the source (and relative age) of chondrocytes during the alginate culture (Table 1).

Table 1. Differences of chondrocyte proliferation in vitro.

\begin{tabular}{|c|c|c|c|c|c|c|}
\hline Origin & Phenotype & Species & Age & Proliferation & Evaluation & Refs. \\
\hline \multirow{8}{*}{$\begin{array}{l}\text { non-human } \\
\text { articular cartilage }\end{array}$} & \multirow{5}{*}{ normal } & bovine & $<5 \mathrm{wk}$ & 2.8-fold increase & $0-20 \mathrm{ds}$ & {$[186]$} \\
\hline & & bovine & $<5$ wk & constant & $20-40 \mathrm{ds}$ & [186] \\
\hline & & bovine & $14-18 \mathrm{mo}$ & 6.9-fold increase & $0-21 \mathrm{ds}$ & [39] \\
\hline & & bovine & $14-18 \mathrm{mo}$ & constant & $21-28 \mathrm{ds}$ & [39] \\
\hline & & porcine & $24 \mathrm{wk}$ & 60 -fold increase & $7-28 \mathrm{ds}$ & [187] \\
\hline & \multirow{3}{*}{ dedifferentiated } & rat & $4-6 w k$ & 2.5-fold increase & $0-40 \mathrm{ds}$ & [188] \\
\hline & & rat & 4-6 wk & constant & $40-60 \mathrm{ds}$ & [188] \\
\hline & & porcine & $10-12 \mathrm{mo}$ & 2.7-fold increase & $7-21 \mathrm{ds}$ & [167] \\
\hline \multirow{11}{*}{$\begin{array}{l}\text { human } \\
\text { articular/nasal } \\
\text { septal cartilage }\end{array}$} & \multirow{6}{*}{ normal } & TKA patient & $\mathrm{N} / \mathrm{A}$ & no increase & $0-20 \mathrm{ds}$ & [162] \\
\hline & & healthy donor & $\mathrm{N} / \mathrm{A}$ & no increase & $0-107 \mathrm{ds}$ & [184] \\
\hline & & healthy donor & $14 \mathrm{yr}$ & minimal increase & $0-10 \mathrm{ds}$ & [27] \\
\hline & & healthy donor & $14 \mathrm{yr}$ & no increase & $10-19$ ds & [27] \\
\hline & & healthy donor & $66 \mathrm{yr}$ & minimal increase & $0-8 \mathrm{ds}$ & [27] \\
\hline & & healthy donor & $66 \mathrm{yr}$ & no increase & $8-19$ ds & [27] \\
\hline & \multirow{5}{*}{ dedifferentiated } & TKA patient & $\mathrm{N} / \mathrm{A}$ & 4-fold decrease & $1-35 \mathrm{ds}$ & [97] \\
\hline & & healthy donor & $5-63$ yr & minimal decrease & $2-7 \mathrm{ds}$ & [94] \\
\hline & & septoplasty patient & $\mathrm{N} / \mathrm{A}$ & 2.5-fold increase & $0-14 \mathrm{ds}$ & [179] \\
\hline & & septoplasty patient & $35 \mathrm{yr}$ & 1.6-fold increase & $0-7 \mathrm{ds}$ & [118] \\
\hline & & septoplasty patient & $35 \mathrm{yr}$ & 2-fold increase & $0-14 \mathrm{ds}$ & [118] \\
\hline
\end{tabular}

Abbreviations: TKA, total knee arthroplasty; N/A, not announced.

Relative to human cells, for instance [167,187], or under stimulation [167,187], significant increases in proliferation rates were reported for porcine chondrocytes $[167,187]$ at any time of the culture period.

Similarly, significant increases were found in bovine [39,186] or rat [188] chondrocytes during a short culture period, after which there were no significant changes in the DNA content of the cells.

Instead, neither significant increases [27] nor minimal increases [162,184] were detected when using normal human chondrocytes at any time of the culture period, but significant increases [179] were noted in dedifferentiated human chondrocytes during a short alginate culture period, followed by decreases in the DNA contents of the cells [94,97]. In normal dedifferentiated chondrocytes, there was a tendency towards increases in the cellularity of monolayer culture and a tendency towards decreases in alginate culture.

\subsubsection{ECM Deposition}

ECM is produced by the chondrocytes and can be found in an intracellular location, in the alginate itself, and in the culture medium [137].

ECM in alginate consists of a cell-associated matrix (a pericellular and territorial matrix) and a removed matrix (an interterritorial matrix) $[23,27,39]$. The pericellular (lacunar) matrix surrounds the chondrocyte plasmalemma as a thin rim rich in PGs but without fibrous proteins (collagens) [189]. The territorial (capsular) matrix adjacent to the pericellular matrix has a fine network characterized by fibrous proteins (collagens) extending around the chondrocytes [189]. The interterritorial matrix surrounds the territorial matrix as the 
outermost domain characterized by fibrous proteins (collagens) running in parallel and interspersed with PGs [189].

A relative volume of cell-associated matrix (5.2\%), removed matrix $(91.3 \%)$, and chondrocytes (3.5\%) can be observed after $13 \mathrm{ds}$ of culture [19,39]. After $30 \mathrm{ds}$, the relative and absolute volumes occupied by the cell-associated matrix $(0.8 \%)$, removed matrix $(97.2 \%)$, and chondrocytes (2\%) are nearly identical to those present in the native articular cartilage (cell-associated matrix: 1.7\%; removed matrix: 96\%; chondrocytes: $2.3 \%$ ) [102].

The chondrocytes produce higher amounts of aggregating PGs (aggrecan, decorin, biglycan, asporin, lumican, and fibromodulin) in alginate gels than in monolayer cultures $[18,190]$. The proportion of PG synthesis is $11.31 \%$ in chondrocytes, $14.83 \%$ in alginate, and $73.86 \%$ in the culture medium (24 h labeling at the end of a 28-day culture period) [137].

In alginate, the proportion of cell-associated matrix synthesis is one third ( $4 \mathrm{~h}$ labeling after a 35-day culture period) [27] or one quarter (4 h labeling after a 9-day culture period [102] or $16 \mathrm{~h}$ labeling after a 12-day culture period) [19], and the proportion of removed matrix synthesis is two thirds or three quarters.

The deposition of PGs in alginate is either a natural cell-associated matrix deposition, a cell-associated matrix re-deposition, or a deposition of naturally removed matrix. In the first case, most newly synthesized GAGs capable of binding to HA form a mature, functional, HA-binding region (e.g., aggregating PGs) for the chondrocytes [27,189]. Due to interactions between HA and CD44-like HA receptors in chondrocytes, a cell-associated matrix is built on the chondrocyte membrane [46,191-193]. Moreover, the concentration of GAGs during cell-associated matrix deposition is similar to that in adult human articular cartilage and is 40-fold higher than in a removed matrix [102]. In the second case, with the matrix removed enzymatically, the addition of exogenous HA and PGs can substitute for endogenous macromolecules and re-assemble a cell-associated matrix within $2 \mathrm{~h} \mathrm{[193].}$

With the continued obstruction of CD44-HA interactions, the chondrocyte cell-associated matrix is displaced and the re-assembly of an endogenous cell-associated matrix is inhibited [191]. Therefore, increases in PGs and HA are insufficient to generate a large cellassociated matrix; instead, increases in CD44-like HA receptors and overall HA-binding capacity are required [193]. In the third case, approximately half of the newly synthesized PGs spend less than $24 \mathrm{~h}$ in the cell-associated matrix before diffusing in the removed matrix of the chondrocytes [189]. The PGs diffused to the removed matrix during the first $24 \mathrm{~h}$ after synthesis are found to lack a functional HA-binding region to keep in the cellassociated matrix [102]. With the gradual saturation of CD44-like HA receptors on the cell membrane after $24 \mathrm{~h}$, more and more aggregating PGs are deposited in the removed matrix.

The accumulation of PG deposition in alginate is controlled by the production of PGs per cell and by the cell density in association with the cell proliferation [178]. The deposition of PGs is gradually accumulated without the effect of the DNA amounts, as seen in a 4-wk study using bovine chondrocytes [39]. The deposition of PGs is more rapidly accumulated with the effect of the DNA amounts, as noted in a 3-wk study using porcine chondrocytes [167]. The mRNA expression of PGs decreases after 4 ds (bovine chondrocytes) [15], but is still detectable after 8 mo of culture using human chondrocytes [194].

Regarding the decomposition of the PG deposition in alginate, the metabolism of PGs is much more dynamic in a cell-associated matrix than in a removed matrix [102,189], with the average half-life of GAGs from the cell-associated matrix being from 15 [189] to 29 ds [102] and that of those from the removed matrix being from 95 [189] to $100 \mathrm{ds}$ [102]. The pool of aggregating PGs has a much longer half-life (2 yr) than that of the non-aggregating PGs that are rapidly lost from the alginate $[27,189]$. The catabolism of aggregating PGs in a cell-associated matrix is the sole significant contributor to the appearance in the medium of partially degraded GAGs that lose the ability to bind to HA [189].

Alginate has a limited capacity to retain GAGs by lack of a functional HA-binding region and/or partial degradation, as most of the GAGs are found in culture medium [137], depending on their weight and shape $[171,195]$. Even though alginate does not retain a 
majority of produced GAGs, the loss of ECM molecules may accelerate the neoformation of cartilage around the implanted bead in vivo [137].

The chondrocytes produce cartilage-specific type-II collagen but not type-I or -X collagen, which are produced when the cells lose their phenotypic stability $[23,171]$. The proportion of collagen deposition in chondrocytes and alginate exceeds $97.5 \%$ and is below $2.5 \%$ in culture medium after a 28-day period [39]. The deposition of fibrous proteins in alginate consists of a normally differentiated deposition of type-II/-IX/-XI collagen and of an abnormally differentiated deposition of type-I/-X collagen. In the first case, type-II/-IX/-XI collagen expression is detected at all times of the culture period $(7 / 15 / 28 \mathrm{ds})$ both in the cellassociated matrix and in the removed matrix in relative proportions $(95 / 1 / 3)$ similar to those in the articular cartilage in its cell-associated matrix [39]. A high proportion of cell-associated matrix deposition/removed matrix deposition can be found for type-II/-IX/-XI collagen and the proportion in type-II or -IX collagen is higher than that in type-XI collagen [39]. In the second case, the accumulation of type- $X$ collagen is very weak and limited to the surface of the alginate [35], indicating that hypertrophic differentiation and endochondral ossification (transdifferentiation) occurs in this region [35,39]. Type-I collagen is synthesized in small amounts by flattened fibroblast-like cells (dedifferentiation) at the edge of alginate, and does not become incorporated as heterotrimers or homotrimers in the matrix [39]. The accumulation of fibrous protein deposition in alginate is also controlled by the production of collagen in each cell and by the cell density, which relates to cell proliferation. The deposition of collagens increases during the culture period with or without the effect of cell proliferation, both in the cell-associated matrix and removed matrix [39].

The mRNA expression of type-II collagen decreases from the first day, while that of type-I collagen increases over an 8-day culture period [15]. The mRNA expression of type-II collagen increases, instead, over a 3-wk culture period, while that of type-I collagen decreases [167]. This is not conflicting, as the former observation has been reported when using normal chondrocytes in alginate while the later was noted in dedifferentiated chondrocytes [34,84]. In addition, the mRNA expression of type-I/-II collagen at $21 \mathrm{ds}$ is similar to that on day 1 of culture [196].

Hydroxy-lysyl pyridinoline (pyridinoline) is the major crosslinking residue $(>93 \%)$ in mature type-II collagen $[35,39,197]$. Lysyl-pyridinoline (deoxy-pyridinoline) is slightly present and forms the crosslinks of type-IX collagen [39,197,198]. Pyridinium crosslinks are detected both in the cell-associated matrix $(90 \%)$ and in the removed matrix $(10 \%)$ at all times, while the content of crosslinks increases with time [35,39]. The ratio of pyridinoline to deoxypyridinoline shows a moderate drop with time in the removed matrix, but an increase with time in the cell-associated matrix [39]. Of note, the crosslinking can be blocked (100\%) by $\beta$-aminopropionitrile (BAPN) without affecting cell proliferation and PG deposition $[35,199]$.

The collagen network in the mature cartilage is detected with an extremely slowly turnover in vivo $\left(t_{1 / 2}>100 \mathrm{yr}\right)$ [200], while the minor collagens in the remodeling or reorganization of the fibrillar network possibly have a more rapid turnover in vitro [39].

Alginate has a powerful capacity to retain collagen and the ECM in alginate is rich in collagen fibers [137], depending on the weight and shape of the molecules (collagens) $[171,195]$. The concentration of collagen in culture medium does not reach a measurable level, but a small proportion of the newly synthesized collagens possibly escape from alginate over the culture period [39].

The deposition of cell-associated matrix and of removed matrix in vitro can be separated using mild centrifugation conditions $\left(100 \times g\right.$ for $10 \mathrm{~min}$ at $4{ }^{\circ} \mathrm{C}[39,102] / 900 \mathrm{rpm}$ for $9 \mathrm{~min}$ [27]/100 g) [35] as the cell-associated matrix is firmly anchored to the chondrocytes via HA strands, while the removed matrix is not. This approach is employed to detect the relationships between the PGs and collagens of the cell-associated matrix and the removed matrix in alginate in vitro. 


\subsubsection{Cell Redifferentiation}

The use of alginate is useful not only to maintain a differentiated phenotype in the chondrocytes, but also to restore a normal phenotype [25] in dedifferentiated chondrocytes, even from OA cartilage [201].

The culture of dedifferentiated chondrocytes in alginate leads to an increased expression of PGs and type-II collagen and to a decreased expression of type-I/type-X collagen $[34,94,97,196,202,203]$.

Redifferentiation permits the occurrence of zonal differences, with the re-deposition of SZP and clusterin (superficial zone) and of COMP and GAGs (deep zone) that disappeared during dedifferentiation [38]. Redifferentiation also re-induces the expression of CD44-like HA receptors that diminished during dedifferentiation [99] and restores the mRNA expression of T $\beta$ RII and the subsequent TGF- $\beta$ response, suppressed during dedifferentiation [100]. Importantly, increasing the duration of the monolayer culture leads to a decreased redifferentiation potential $[84,96,204,205]$, while increasing that of alginate culture leads to an increased redifferentiation ability (Figure 4) [206-208].

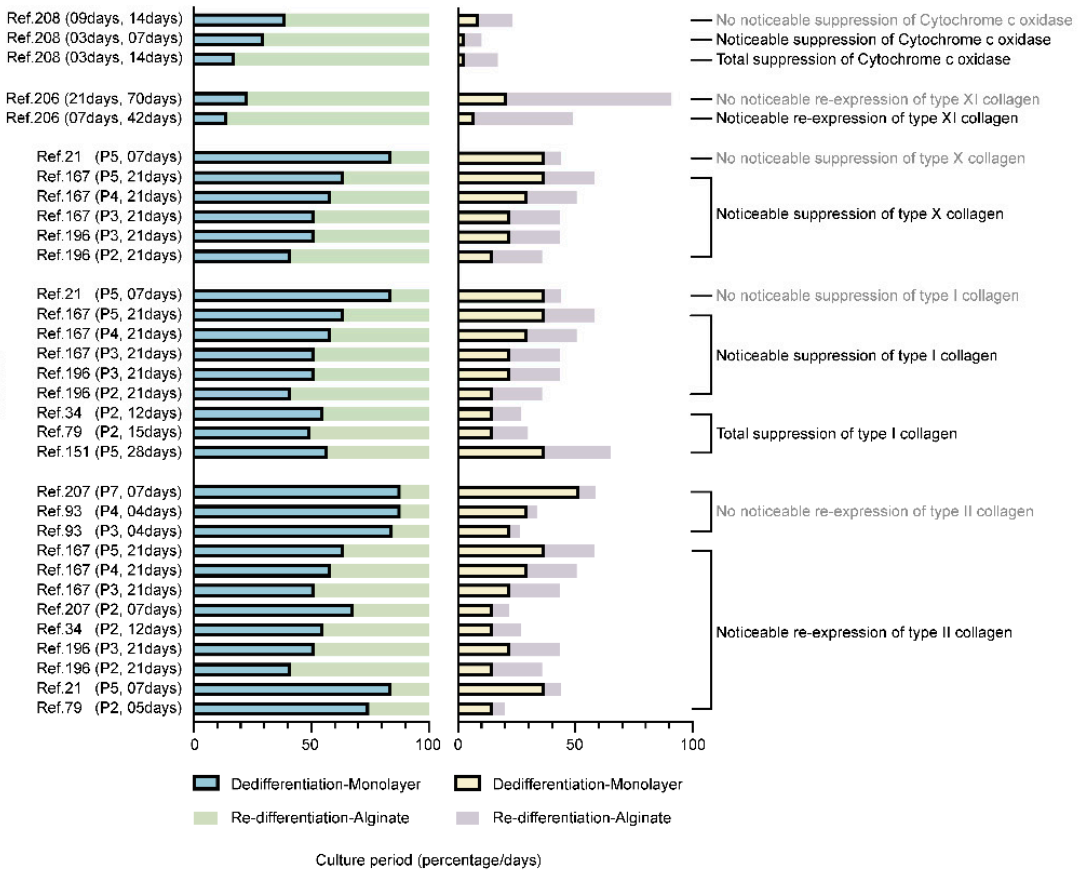

b

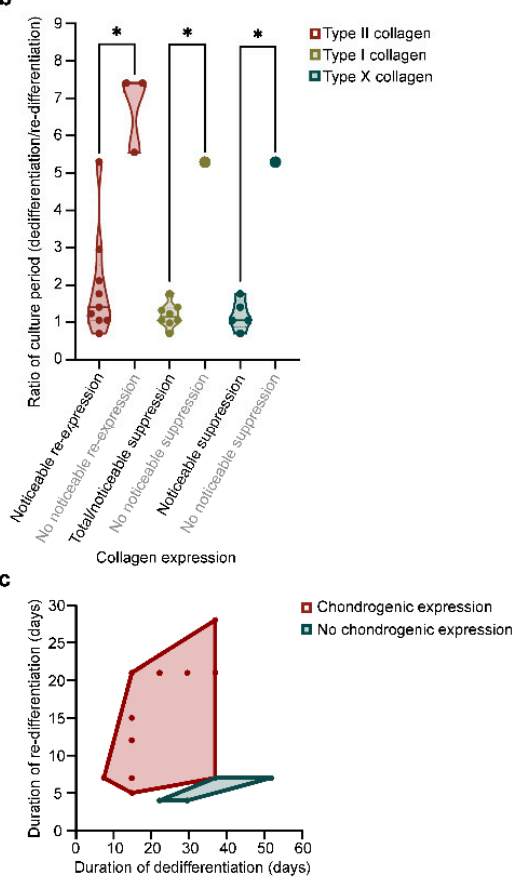

Figure 4. Relationship between the cell redifferentiation abilities. (a) Modification of cell expression associated with the relative/absolute relationship between dedifferentiation and redifferentiation (duration of passage: 7.4 ds, according to [21,34,79,93,151,167,196,206-208]). (b) Ratio (dedifferentiation/redifferentiation) for collagen expression (* indicates statistically significant differences between groups). (c) Relationship between chondrogenic expression (PGs, type-II/-I/-X/-III collagen) and culture period (dots represent independent publications matching the parameters of duration of chondrocyte redifferentiation versus differentiation) (created with Prism $(\mathbf{a}, \mathbf{b})$ and Past (c)).

Decreasing the chondrocyte seeding density in the monolayer culture $\left(3 \times 10^{4}\right.$ to $3.5 \times 10^{3}$ cells $/ \mathrm{cm}^{2}$, duration of passage: 4 ds versus 21 in alginate) [209] or in alginate $\left(10^{6}\right.$ to $10^{4}$ cells $/ \mathrm{mL}$, duration of passage: 28 ds versus 3 in the monolayer culture) [33] improves their redifferentiation capacity. This needs to be taken into account, as dedifferentiated cells have been wrongly seen as differentiated cells $[166,167,188,210,211]$. Chondrocyte redifferentiation in alginate [212] versus other materials (Figure 5) involves several pathways identified using physicochemical and biological stimuli (hypoxia, hydrostatic pressure, oxygen, seeding density, co-culture, temperature, and growth factors/genes, such as bone morphogenetic proteins (BMPs), TGF- $\beta$, insulin-like growth factor I (IGF-I), basic fibroblast growth factor (FGF-2), platelet-derived growth factor (PDGF), EGF, platelet-rich plasma 
(PRP), platelet lysate, ECM), or inhibitors of calcineurin, Rho activation, activin A, transglutaminase 2, and extracellular signal-regulated protein kinase (ERK1/2) [33,36,201,213-251].
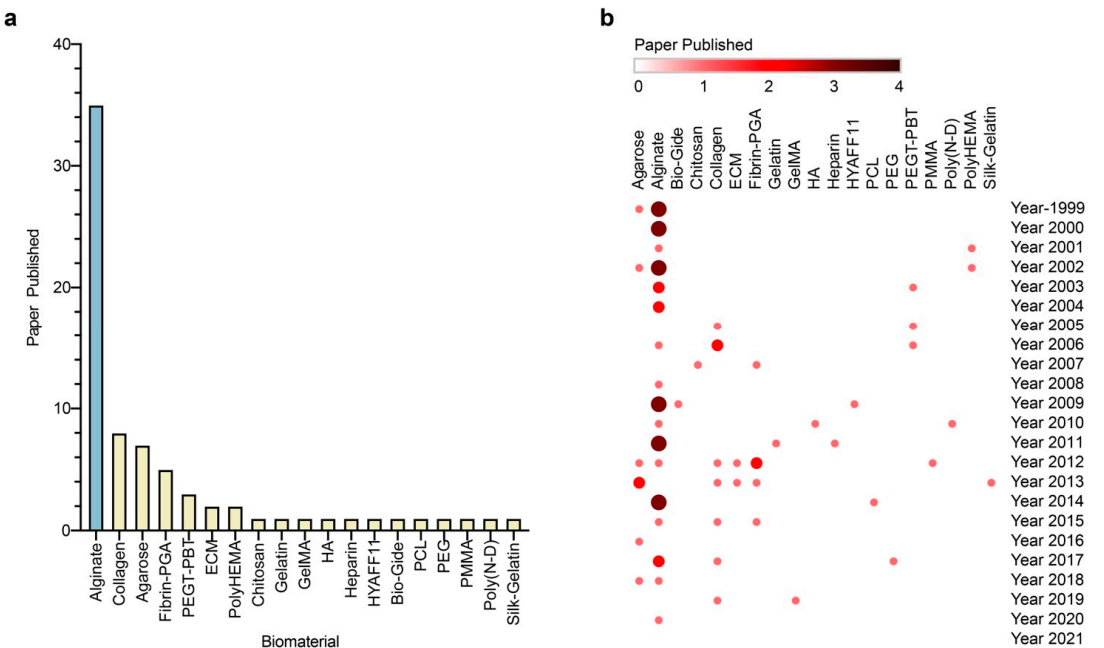

Figure 5. Use of alginate for chondrocyte redifferentiation versus other materials. Biomaterials used for chondrocyte redifferentiation in total (a) and annual (b) publications. PGA, poly(glycolic acid); GelMA, gelatin methacryloyl; HA, hyaluronic acid; PCL, poly( $\varepsilon$-caprolactone); PEG, polyethylene glycol; PEGT-PBT, polyethylene glycol terephthalate/polybutylene terephthalate; PMMA, poly(methyl methacrylate); Poly(N-D), poly(NaAMPS-co-DMAAm); PolyHEMA, poly-(2-hydroxyethyl methacrylate); created with Prism (a) and Morpheus (b).

Chondrocyte redifferentiation is generally accompanied with an enhanced expression of the cartilage-specific sex-determining region Y-type high mobility box 9 (SOX9) transcription factor $[252,253]$ via the p38 MAPK (a mitogen-activated protein kinase related to the c-Jun N-terminal kinase (JNK)) signaling pathway [254], activating ECM synthesis (PGs, type-II collagen) [255]. Redifferentiation may occur via the TGF- $\beta /$ T $\beta$ RII, FGF-2/FGF receptor 3 (FGFR3), and protein kinase C (PKC), ERK, and focal adhesion kinase (FAK) signaling pathways $[100,202,256,257]$.

\subsection{In Vivo Studies}

Engrafted alginate-chondrocyte systems have been tested in vivo and the subsequent findings of cartilage structure formation were demonstrated using either the extra- or intra-articular application of the systems (Table 2) [82,138,166,211,258-262].

Table 2. Implantation of alginate-chondrocyte systems.

\begin{tabular}{|c|c|c|c|c|c|}
\hline Approach & Model & Evaluation & Cartilage Regeneration & Fibrous Tissue & Refs. \\
\hline \multirow{5}{*}{ extra-articular } & dorsal s.c. tissue (nude mouse) & $6-12 \mathrm{wk}$ & + & $\mathrm{N} / \mathrm{A}$ & [258] \\
\hline & dorsal s.c. pocket (athymic mouse) & $8-12$ wk & + & $\mathrm{N} / \mathrm{A}$ & [138] \\
\hline & dorsal s.c. tissue (nude mouse) & $14-38 \mathrm{wk}$ & + & minor & [259] \\
\hline & dorsal s.c. tissue (SCID mouse) & $2-6 \mathrm{wk}$ & + & - & [166] \\
\hline & gluteus muscle (rabbit) & $4-20 w k$ & + & $\mathrm{N} / \mathrm{A}$ & [260] \\
\hline \multirow{4}{*}{ intra-articular } & femoral condyle OCDs (rabbit) & $4-24 \mathrm{wk}$ & + & N/A & [261] \\
\hline & trochlear groove OCDs (rabbit) & $1-4 \mathrm{wk}$ & minor & major & [82] \\
\hline & femoral condyle, patella, and trochlea CDs (human) & $1-8 \mathrm{yr}$ & $\mathrm{N} / \mathrm{A}$ & $\mathrm{N} / \mathrm{A}$ & [262] \\
\hline & femoral condyle and trochlea OCDs (sheep) & $1-21 \mathrm{ds}$ & - & + & [211] \\
\hline
\end{tabular}

Abbreviations: s.c., subcutaneous; SCID, severe combined immunodeficiency; OCDs, osteochondral defects; CDs, chondral defects; +, detected; -, undetected; N/A, not announced.

\subsubsection{Extra-Articular Implantation}

Chondrocytes engrafted in alginate and extra-articularly implanted in vivo can be detected at the site of implantation for the entire period of observation with increased cell densities over time in lapine [260], bovine [138], and porcine models [166]. 
Chondrocytes become surrounded with basophilic ground substance between 4 and $20 \mathrm{wk}$ in vivo [138,258,260] with an accumulation of ECM deposition for at least $6 \mathrm{wk}$ [166]. PGs and type-II collagen [259] can be detected in the grafts (4-20 wk/4-28 wk) [138,258,260] with increases in deposition also for up to $6 \mathrm{wk}$ [166]. The mRNA expression of PGs and type-II collagen decreases over time (wk 2/4/6) with a short period of up-regulation (wk 2/4) followed by a period of down-regulation (wk 6) [166]. The mRNA expression of type-X and -I collagen remains stable to nearly undetectable levels over time (wk 2/4/6) [166].

The grafts show an irregular, gradually pearly opalescence, firm but flexible to palpation, and resembling the native articular cartilage at the time of harvest [138,166,258-260]. They are surrounded by a thin layer of fibrous tissue characterized by a vascular network relating to nutritional supply [138,258-260]. They exhibit an increasing weight after incubation for $12 \mathrm{wk}$ [258] that remains stable until after 38 and 20 [259] wk.

\subsubsection{Intra-Articular Implantation}

Chondrocytes intra-articularly transplanted in vivo can be detected in the repair tissue during the whole period of observation without evidence of strictly increased or reduced cell densities in lapine [82] and ovine [211] models. Of note, chondrocytes labelled via transfection methods may be varied during cell density detection, as the number of transfected cells may differ from that of non-transfected cells in alginate [82,211].

There is no indication of the migration of engrafted chondrocytes in the host articular cartilage or of the integration of the regenerated cartilage with the host articular cartilage [82]. The is also no evidence of the accumulation of basophilic ground substance deposition nor of increases in PG deposition without the formation of fibrous tissue, even though these were detected respectively $[82,261]$.

Over a follow-up period of about $6 \mathrm{yr}$, there is a remarkable difference between favorable clinical determination (Western Ontario and McMaster Universities Osteoarthritis Index (WOMAC) score; visual analog scale (VAS)) and the moderate to poor MRI findings (Magnetic Resonance Observation of Cartilage Repair Tissue (MOCART) score) [262]. Magnetic resonance imaging (MRI) scores do not show satisfactory results of cartilage lesion regeneration, while clinical scores cannot predict the long-term durability of outcomes, even though severe clinical deterioration or adverse reactions are not observed [262]. Additionally, the application of alginate with agarose for ACI offered safe and durable cartilage repair over a period of $18 \mathrm{yr}$ [263].

\subsubsection{Implantation Methods}

Implantation is performed via injection or arthrotomy to deliver large amounts of isolated chondrocytes as a means to promote engraftment and cartilage formation [258]. Higher seeding densities are commonly employed in vivo with stable concentrations of alginate and gelling solution compared with the conditions used in vitro (Table 3).

At implantation, a rapid gelation may limit the minimal invasion and relatively adequate mixing, which may be retarded by temperature dropping $\left(4^{\circ} \mathrm{C}\right)[120,258]$ and with cations $\left(\mathrm{CaSO}_{4} / \mathrm{Na}_{2} \mathrm{HPO}_{4}\right)$ (Table 4) [264].

Table 3. Implantation conditions of alginate-chondrocyte systems.

\begin{tabular}{|c|c|c|c|c|c|}
\hline Gelation Approach & Gelling Solution & Alginate (wt/vol \%) & Cells $\left(10^{6} / \mathrm{mL}\right)$ & Gelling Solution/Alginate & Refs. \\
\hline adhesion & $\mathrm{CaCl}_{2}(180 \mathrm{mM})$ & 1.5 & 120 & $\mathrm{~N} / \mathrm{A}$ & [166] \\
\hline \multirow{8}{*}{ encapsulation } & $\mathrm{CaCl}_{2}(50 \mathrm{mM})$ & 0.75 & $20-30$ & $\mathrm{~N} / \mathrm{A}$ & [261] \\
\hline & $\mathrm{CaCl}_{2}(102 \mathrm{mM})$ & 1 & 20 & N/A & [262] \\
\hline & $\mathrm{CaCl}_{2}$ (N/A) & 2 & 20 & $300 \mu \mathrm{L} / 500 \mu \mathrm{L}$ & [259] \\
\hline & $\mathrm{CaCl}_{2}(102 \mathrm{mM})$ & 1.2 & 10 & N/A & [82] \\
\hline & $\mathrm{CaCl}_{2}(102 \mathrm{mM})$ & 1.2 & 4 & N/A & [211] \\
\hline & $\mathrm{CaCl}_{2}(15-100 \mathrm{mM})$ & $0.5-4.0$ & $0 / 1 / 5 / 10$ & N/A & [138] \\
\hline & $\mathrm{CaSO}_{4}(200 \mathrm{mM})$ & 1.8 & 10 & $1 \mathrm{~mL} / 2 \mathrm{~mL}$ & [260] \\
\hline & $\mathrm{CaSO}_{4}(1470 \mathrm{mM})$ & 1 & 10 & $0.2 \mathrm{~g} / 1 \mathrm{~mL}$ & [258] \\
\hline
\end{tabular}

Abbreviations: N/A, not announced. 
Table 4. Implantation methods of alginate-chondrocyte systems.

\begin{tabular}{|c|c|c|c|}
\hline Method & Preparation & Mixing & Refs. \\
\hline implantation of two solutions one by one with operation/mixing/gelling & invasive & inadequate & [261] \\
\hline mixing/gelling implantation with gelation at operation & invasive & adequate & {$[82,138,166,211,262]$} \\
\hline implantation of two solutions one by one with injection via mixing/gelling & not invasive & inadequate & {$[259]$} \\
\hline mixing (Pantaject)-based implantation with injection/gelling & not invasive & inadequate & [260] \\
\hline mixing (vortex)-based implantation with injection-gelling (low temperature) & not invasive & adequate & [258] \\
\hline
\end{tabular}

Clinical implantation procedures include the management of chondrocytes for intraarticular application (harvesting, expansion, encapsulation), the preparation of the defect (cleaning, regularization), the implantation of the engrafted system, and the possible use of a periosteal flap sealing [262].

In the case of an acellular implantation, in situ gelation is preferred at the time of the operation without additional fixation of the augmentation site [163].

\subsection{Overview and Limitations}

While chondrocytes are known to better maintain their phenotype in alginate versus monolayer cultures, their proliferation for natural turnover and ECM deposition in this 3D conformation are still insufficient for effective cartilage regeneration. Therefore, the addition of appropriate exogenous repair stimuli may improve the capability of chondrocyte proliferation and ECM deposition in alginate culture [80,144,265].

\section{Alginate, Chondrocytes, and Biological/Physicochemical Stimulation for Articular Cartilage Regeneration}

Experimental conditions have thus been further expanded to enhance the potential of chondrocytes in alginate via a number of stimuli to further enhance the processes of cartilage regeneration.

Such stimuli include biologics (growth factors), physicochemical components (tension, shearing force, perfusion, hydrostatic pressure, oxygen tension, osmotic pressure, ultrasounds), and other types of stimulation (rhein, ascorbic acid, chlorogenic acid, cyclodextrin polysulfates, flavonoid compound icariin, BAPN).

Most investigation has been performed in experimental studies in vitro and partly in vivo, as detailed below.

\subsection{In Vitro Studies}

\subsubsection{Biological Stimulation}

Biological stimuli include various factors, most particularly growth factors, such as IGF-I, TGF- $\beta$, FGF-2, osteogenic protein 1 (OP-1), and BMP-2 (Table 5) [19,80,84,185,193,266-274].

Table 5. Biological stimulation of alginate-chondrocyte systems.

\begin{tabular}{|c|c|c|c|c|c|c|c|c|c|c|}
\hline \multirow{2}{*}{\multicolumn{2}{|c|}{ Stimulus (ng/mL) }} & \multirow{2}{*}{ Cells } & \multirow{2}{*}{$\begin{array}{l}\text { Alginate, } \\
\text { Serum (ds) }\end{array}$} & \multirow{2}{*}{$\begin{array}{c}\text { Viability, } \\
\text { Proliferation }\end{array}$} & \multicolumn{2}{|c|}{ PG Synthesis } & \multicolumn{2}{|c|}{ PG Deposition } & \multirow{2}{*}{ Collagen Deposition } & \multirow[b]{2}{*}{ Refs. } \\
\hline & & & & & Total & Individual & Total & Individual & & \\
\hline \multirow{7}{*}{ IGF-I } & $100(21 \mathrm{ds})$ & human & - & slight increase & N/A & N/A & N/A & slight increase & N/A & [185] \\
\hline & $100-1000(28 \mathrm{ds})$ & human & - & N/A & N/A & increase to decrease & N/A & slight increase & N/A & {$[266]$} \\
\hline & $100(21 \mathrm{ds})$ & human & - & slight increase & N/A & N/A & slight increase & slight increase & slight increase & {$[267,268]$} \\
\hline & $25(13 \mathrm{ds})$ & bovine &,$- 10 \%(13 \mathrm{ds})$ & slight increase & increase & N/A & increase & N/A & N/A & {$[19]$} \\
\hline & $100(7 \mathrm{ds})$ & human & $2.5 \%(7 \mathrm{ds})$ & N/A & N/A & N/A & increase & N/A & increase & [269] \\
\hline & $2.5-25(20-35 \mathrm{ds})$ & bovine & $10 \%(20-35 \mathrm{ds})$ & slight decrease & N/A & N/A & increase & N/A & increase & [270] \\
\hline & $100(14 \mathrm{ds})$ & human & $10 \%(14 \mathrm{ds})$ & increase & N/A & increase & N/A & $\mathrm{N} / \mathrm{A}$ & N/A & [271] \\
\hline \multirow{3}{*}{ TGF- $\beta$} & $10(7-28 \mathrm{ds})$ & rabbit & $10 \%(7-28 \mathrm{ds})$ & slight increase & N/A & N/A & N/A & increase & N/A & [84] \\
\hline & $25(13 \mathrm{ds})$ & bovine &,$- 10 \%(13 \mathrm{ds})$ & slight increase & increase & N/A & increase & N/A & N/A & [19] \\
\hline & $2.5-25(20-35 \mathrm{ds})$ & bovine & $10 \%(20-35 \mathrm{ds})$ & slight decrease & N/A & N/A & decrease & N/A & decrease & [270] \\
\hline \multirow{2}{*}{ FGF-2 } & $1-100(21 \mathrm{ds})$ & human & & increase & N/A & slight decrease & N/A & decrease & N/A & [268] \\
\hline & $2.5-25(20-35 \mathrm{ds})$ & bovine & $10 \%(20-35 \mathrm{ds})$ & slight increase & N/A & N/A & increase & N/A & increase to decrease & [270] \\
\hline \multirow{6}{*}{ OP-1 } & $100(21 \mathrm{ds})$ & human & - & increase & N/A & slight increase & increase & increase & increase & {$[185,266-268]$} \\
\hline & $50(7 \mathrm{ds})$ & human & $10 \%(7 \mathrm{ds})$ & slight increase & increase & N/A & N/A & N/A & N/A & {$[272]$} \\
\hline & $100(14 \mathrm{ds})$ & bovine & $5 \%(14 \mathrm{ds})$ & N/A & N/A & slight increase & N/A & N/A & N/A & {$[193]$} \\
\hline & $100(14 \mathrm{ds})$ & bovine & $10 \%(14 \mathrm{ds})$ & increase & N/A & N/A & increase & increase & increase & {$[273]$} \\
\hline & $200-1000(21 \mathrm{ds})$ & human &,$- 10 \%(21 \mathrm{ds})$ & N/A & N/A & N/A & increase & N/A & N/A & [274] \\
\hline & $100(14 \mathrm{ds})$ & human & $10 \%(14 \mathrm{ds})$ & increase & N/A & increase & N/A & N/A & $\mathrm{N} / \mathrm{A}$ & [271] \\
\hline BMP-2 & $100(14 \mathrm{ds})$ & human & $10 \%(14 \mathrm{ds})$ & N/A & N/A & increase & N/A & N/A & N/A & [80] \\
\hline
\end{tabular}

Abbreviations: IGF-I, insulin-like growth factor I; TGF- $\beta$, transforming growth factor beta; FGF-2, basic fibroblast growth factor; OP-1, osteogenic protein 1; BMP-2, bone morphogenetic protein 2; -, free of serum; N/A, not announced; PG, proteoglycans. 
IGF-I is a key intrinsic factor involved in the articular cartilage homeostasis [275] associated with degeneration and regeneration [145]. Chondrocyte viability and proliferation is minimally influenced by the addition of IGF-I in the absence of serum, while PG and type-II collagen deposition is slightly affected, regardless of the cell numbers $[185,268]$. Chondrocyte viability and proliferation is also minimally affected by the addition of IGF-I in the presence of serum, but PG and type-II collagen deposition is significantly increased, regardless of the cell numbers $[19,269,270]$. For individual cells, PG synthesis increases for a short time and then decreases in association with the activation of anabolic (PI3K activity) and catabolic pathways upon the addition of IGF-I in the absence of serum [276].

TGF- $\beta$ is also an intrinsic factor that is secreted as a latent high molecular weight complex in the articular cartilage, becoming activated upon complex dissociation [84]. Chondrocyte proliferation in alginate is not affected by the addition of TGF- $\beta 2$ in the presence of serum [84,270], but PG synthesis is significantly increased, regardless of the cell numbers [19]. PG deposition is associated with ECM assembly, with the reduction of relative volume in cell-associated matrix as a result of external TGF- $\beta 2$ stimulation with serum [19], which can be blocked gradually during ECM formation [84].

FGF-2, a member of the multifunctional fibroblast growth factor family, displays mitogenic activities in chondrocytes $[268,277,278]$. Chondrocyte viability is not altered by the addition of FGF-2, yet proliferation is stimulated regardless of the presence of serum, while PG deposition decreases in a dose-dependent manner in individual cells [268,270]. The synthesis of PGs is slightly affected by FGF-2, showing an increased degradation regardless of the cell numbers [268]. FGF-2 can also block the improved PG synthesis mediated by IGF-I and OP-1 [268].

OP-1 (BMP-7) is an anabolic growth factor of the TGF superfamily expressed in the articular cartilage $[185,271,274]$. The addition of OP-1 results in both increased cell proliferation and PG deposition in the presence or absence of serum, regardless of the cell numbers [93,185,193,267,268,271-273]. For individual cells, PG synthesis and type-II collagen deposition are rarely affected by the addition of OP-1 and differences between the deposition and synthesis of PGs have been related to a diminished catabolism [273].

BMP-2 plays key roles in chondrocyte differentiation and ECM maturation [80]. The synthesis of PGs and type-II collagen by individually dedifferentiated chondrocytes is significantly increased by the addition of BMP-2 in the presence of serum [80]. Interestingly, such stimulating effects may be affected by different phenotypes [84,271]. Therefore, it appears to be important to take these observations into careful account, as dedifferentiated cells do not represent cells with a normal phenotype $[80,98,271]$.

\subsubsection{Physicochemical Stimulation}

The process by which mechanical loading influences the metabolism of the chondrocytes in alginate is called mechanotransduction [130]. The various types of mechanical stress applied to alginate where the chondrocytes are embedded include tension, shearing force, and hydrostatic pressure (Table 6) [20,23,36,219,279-294], and these can influence each other [280,281]. 
Table 6. Physicochemical stimulation of alginate-chondrocyte systems.

\begin{tabular}{|c|c|c|c|c|c|c|c|c|c|c|c|}
\hline & \multirow{2}{*}{ Stimulus } & \multirow{2}{*}{ Cells } & \multirow{2}{*}{$\begin{array}{l}\text { Alginate, } \\
\text { Serum (ds) }\end{array}$} & \multirow{2}{*}{ Proliferation } & \multicolumn{2}{|c|}{ PG Synthesis } & \multicolumn{2}{|c|}{ PG Deposition } & \multirow{2}{*}{$\begin{array}{l}\text { Collagen } \\
\text { Synthesis }\end{array}$} & \multirow{2}{*}{$\begin{array}{l}\text { Collagen } \\
\text { Deposition }\end{array}$} & \multirow{2}{*}{ Refs. } \\
\hline & & & & & Total & Individual & Total & Individual & & & \\
\hline \multirow{3}{*}{ tension } & $0-40 \%$ compression, $0 \mathrm{~Hz}, 22 \mathrm{~h}$ & bovine & $10 \%(21 \mathrm{ds})$ & N/A & decrease & $\mathrm{N} / \mathrm{A}$ & N/A & $\mathrm{N} / \mathrm{A}$ & N/A & N/A & [20] \\
\hline & $20 \%$ sin. strain, $0.5 \mathrm{~Hz}, 22 \mathrm{~h}$ & bovine & $10 \%(21 \mathrm{ds})$ & $\mathrm{N} / \mathrm{A}$ & increase & N/A & $\mathrm{N} / \mathrm{A}$ & N/A & N/A & N/A & [20] \\
\hline & $15-50 \%$ sin. strain, $1 \mathrm{~Hz}, 1-3 \mathrm{~h}$ & $\begin{array}{l}\text { human } \\
\text { dedifferentiated }\end{array}$ & - (14 ds) & $\mathrm{N} / \mathrm{A}$ & $\mathrm{N} / \mathrm{A}$ & increase & N/A & $\mathrm{N} / \mathrm{A}$ & increase & $\mathrm{N} / \mathrm{A}$ & [282] \\
\hline \multirow{3}{*}{$\begin{array}{l}\text { shearing force, } \\
\text { perfusion }\end{array}$} & $0.025 \mathrm{~mL} / \mathrm{h}, 9 \mathrm{ds}$ & bovine & - & slight decrease & $\mathrm{N} / \mathrm{A}$ & $\mathrm{N} / \mathrm{A}$ & $\mathrm{N} / \mathrm{A}$ & increase & $\mathrm{N} / \mathrm{A}$ & increase & [283] \\
\hline & $180 \mathrm{~mL} / \mathrm{h}, 7-14 \mathrm{ds}$ & $\begin{array}{c}\text { bovine } \\
\text { dedifferentiated }\end{array}$ & $10 \%$ & increase & $\mathrm{N} / \mathrm{A}$ & increase & $\mathrm{N} / \mathrm{A}$ & N/A & $\begin{array}{l}\text { decrease to } \\
\text { increase }\end{array}$ & N/A & [284] \\
\hline & $6 \mathrm{~mL} / \mathrm{h}, 16 \mathrm{ds}$ & $\begin{array}{c}\text { human } \\
\text { dedifferentiated }\end{array}$ & $10 \%$ & N/A & $\mathrm{N} / \mathrm{A}$ & slight effect & N/A & decrease & increase & N/A & [281] \\
\hline \multirow{4}{*}{$\begin{array}{l}\text { hydrostatic } \\
\text { pressure }\end{array}$} & 1.2-2.4 MPa, $0 \mathrm{~Hz}, 4 \mathrm{~h}$ & goat & $10 \%$ & $\mathrm{~N} / \mathrm{A}$ & $\mathrm{N} / \mathrm{A}$ & $\mathrm{N} / \mathrm{A}$ & $\mathrm{N} / \mathrm{A}$ & decrease & N/A & decrease & [285] \\
\hline & $1.2-2.4 \mathrm{MPa}, 0.66 \mathrm{~Hz}, 4 \mathrm{~h}$ & goat & $10 \%$ & N/A & N/A & N/A & N/A & increase & $\mathrm{N} / \mathrm{A}$ & decrease & [285] \\
\hline & $10 \mathrm{MPa}, 0 \mathrm{~Hz}, 12 \mathrm{~h}$ & rabbit & $10 \%$ & $\mathrm{~N} / \mathrm{A}$ & $\mathrm{N} / \mathrm{A}$ & increase & $\mathrm{N} / \mathrm{A}$ & $\mathrm{N} / \mathrm{A}$ & increase & $\mathrm{N} / \mathrm{A}$ & [279] \\
\hline & $50 \mathrm{MPa}, 0 \mathrm{~Hz}, 12 \mathrm{~h}$ & rabbit & $10 \%$ & $\mathrm{~N} / \mathrm{A}$ & $\mathrm{N} / \mathrm{A}$ & decrease & $\mathrm{N} / \mathrm{A}$ & $\mathrm{N} / \mathrm{A}$ & decrease & $\mathrm{N} / \mathrm{A}$ & [279] \\
\hline \multirow{6}{*}{$\begin{array}{l}\text { oxygen } \\
\text { tension }\end{array}$} & $0-20 \%, 7 \mathrm{ds}$ & bovine & $10 \%$ & slight effect & $\mathrm{N} / \mathrm{A}$ & slight effect & $\mathrm{N} / \mathrm{A}$ & $\mathrm{N} / \mathrm{A}$ & $\mathrm{N} / \mathrm{A}$ & $\mathrm{N} / \mathrm{A}$ & [286] \\
\hline & $1-21 \%, 14 \mathrm{ds}$ & equine & - & slight effect & $\mathrm{N} / \mathrm{A}$ & $\mathrm{N} / \mathrm{A}$ & $\mathrm{N} / \mathrm{A}$ & N/A & $\mathrm{N} / \mathrm{A}$ & $\mathrm{N} / \mathrm{A}$ & [287] \\
\hline & $5 \%, 7-28 \mathrm{ds}$ & $\begin{array}{c}\text { bovine } \\
\text { dedifferentiated }\end{array}$ & $10 \%$ & N/A & N/A & increase & $\mathrm{N} / \mathrm{A}$ & $\mathrm{N} / \mathrm{A}$ & increase & $\mathrm{N} / \mathrm{A}$ & [203] \\
\hline & $5 \%, 21 \mathrm{ds}$ & $\begin{array}{c}\text { bovine } \\
\text { dedifferentiated }\end{array}$ & $10 \%$ & N/A & N/A & $\mathrm{N} / \mathrm{A}$ & increase & N/A & N/A & increase & [219] \\
\hline & $5 \%, 28 \mathrm{ds}$ & $\begin{array}{c}\text { human } \\
\text { dedifferentiated }\end{array}$ & $10 \%$ & increase & $\mathrm{N} / \mathrm{A}$ & increase & N/A & increase & increase & N/A & [288] \\
\hline & $5-21 \%, 14 \mathrm{ds}$ & $\begin{array}{c}\text { human } \\
\text { dedifferentiated }\end{array}$ & $10 \%$ & slight effect & N/A & $\mathrm{N} / \mathrm{A}$ & $\mathrm{N} / \mathrm{A}$ & N/A & N/A & slight effect & [289] \\
\hline \multirow{6}{*}{$\begin{array}{l}\text { osmotic } \\
\text { pressure }\end{array}$} & $280 \mathrm{mOsm}, 12 \mathrm{ds}$ & bovine & $10 \%$ & increase & N/A & N/A & N/A & decrease & N/A & slight effect & [290] \\
\hline & $280-550 \mathrm{mOsm}, 5 \mathrm{ds}$ & bovine & $10 \%$ & slight effect & N/A & N/A & N/A & slight effect & N/A & slight effect & [290] \\
\hline & $550 \mathrm{mOsm}, 12 \mathrm{ds}$ & bovine & $10 \%$ & slight effect & $\mathrm{N} / \mathrm{A}$ & N/A & N/A & slight effect & N/A & slight effect & [290] \\
\hline & $270-570$ mOsm, 2-6 ds & bovine & $6 \%$ & N/A & N/A & decrease & decrease & N/A & $\mathrm{N} / \mathrm{A}$ & N/A & [291] \\
\hline & $270 \mathrm{mOsm}, 2 \mathrm{ds}$ & bovine & - & N/A & N/A & decrease & N/A & N/A & N/A & N/A & [292] \\
\hline & $550 \mathrm{mOsm}, 2 \mathrm{ds}$ & bovine & - & N/A & N/A & increase & N/A & $\mathrm{N} / \mathrm{A}$ & $\mathrm{N} / \mathrm{A}$ & $\mathrm{N} / \mathrm{A}$ & [292] \\
\hline \multirow{3}{*}{ ultrasounds } & $2 \mathrm{~mW} / \mathrm{cm}^{2}, 1.5 \mathrm{MHz}, 20 \mathrm{~min}$ & chick & $10 \%$ & slight effect & $\mathrm{N} / \mathrm{A}$ & decrease & slight effect & N/A & $\begin{array}{l}\text { decrease to } \\
\text { increase }\end{array}$ & increase & [293] \\
\hline & $30 \mathrm{~mW} / \mathrm{cm}^{2}, 1.5 \mathrm{MHz}, 20 \mathrm{~min}$ & chick & $10 \%$ & decrease & $\mathrm{N} / \mathrm{A}$ & slight effect & slight effect & $\mathrm{N} / \mathrm{A}$ & increase & slight effect & [293] \\
\hline & $100 \mathrm{~mW} / \mathrm{cm}^{2}, 1.5 \mathrm{MHz}, 20 \mathrm{~min}$ & $\begin{array}{l}\text { human } \\
\text { dedifferentiated }\end{array}$ & $10 \%$ & slight effect & increase & $\mathrm{N} / \mathrm{A}$ & increase & $\mathrm{N} / \mathrm{A}$ & increase & slight effect & [294] \\
\hline
\end{tabular}


Regarding tension, static compression may affect the deformation of chondrocytes depending on the concentration of alginate, with a durability of cell distortion parallel to the viscoelasticity of alginate [130]. Static compression is known to decrease the synthesis of PGs in the chondrocytes, while cyclic compression increases it, and sulfate incorporation is affected by mechanical compression [20]. The effect of compression is linked to the duration, intensity, and frequency of the tension, to the incubation period before and after mechanical stimulation, and to the chondrocyte phenotype [20,282]. The increasing effect of shearing force is associated with the duration and velocity of the perfusion method, with the incubation period before and after stimulation, and with the chondrocyte phenotype $[281,283,284]$. The distribution of PGs is more uniform in perfusion culture, and a higher PG deposition can be found both in the outer regions of the alginate and in the culture medium $[281,283]$. The positive effect of hydrostatic pressure is also related to the duration, intensity, and frequency of stimulation, to the incubation time before and after stimulation, and to the chondrocyte phenotype $[279,285]$.

The articular cartilage is a physiologically hypoxic tissue [295], with a gradient of oxygen tension ranging from about 10\% [286] (7.5\%) [203] at the cartilage surface to less than $1 \%[203,286]$ in the deepest layers. In conditions where the oxygen tension is less than $0.1 \%$ [286] or more than $50 \%$ [203], the metabolism of the chondrocytes in alginate is severely compromised. Dedifferentiated chondrocytes are sensitive to hypoxia $[36,203,219,288]$, in contrast to differentiated [286,287] and septal chondrocytes [289]. Cell viability and proliferation are independent from hypoxia [36,288], which may however increase the synthesis and deposition of PGs and type-II collagen in dedifferentiated chondrocytes, regardless of the cell numbers (Table 6) [36,203,219,288].

Extracellular osmotic pressure is mainly determined by the local PG concentration in the different articular cartilage zones, ranging from about $350 \mathrm{mOsm}$ in the superficial zone to about $450 \mathrm{mOsm}$ in the middle zone $[296,297]$. The effect of hypotonic ( $<300 \mathrm{mOsm}$ ) or hypertonic ( $>500 \mathrm{mOsm}$ ) medium changes for chondrocytes embedded in alginate is associated with the duration and magnitude of stimulation and with the culture medium [290-292]. Furthermore, chondrocytes are more sensitive to hypotonic than to hypertonic pressure, with mostly negative effects (Table 6).

The effects of ultrasounds on chondrocytes in alginate are related to the duration, intensity, and frequency of stimulation and to the cell phenotype, but without strong effects on cell viability and proliferation or on ECM deposition (Table 6) [293,294].

\subsubsection{Other Stimuli}

Chondrocyte proliferation and ECM deposition in alginate may also be influenced by rhein enhancing the PG deposition [298], ascorbic acid increasing the levels of cell proliferation, but without effect on type-II collagen deposition [299], chlorogenic acid promoting higher levels of cell proliferation and of total PG deposition [300], cyclodextrin polysulfates enhancing the total synthesis/deposition of PGs and of type-II collagen [301], flavonoid compound icariin increasing cell proliferation and the synthesis/deposition of PGs and of type-II collagen [302], or even BAPN stimulating the total deposition of PGs and of type-II collagen [199] while lidocaine may inhibit such effects in the cells [303-305].

\subsection{In Vivo Studies}

Thus far, there is relatively little information on applying such stimuli to chondrocytes in alginate in vivo, since adapted interventions are not easy to control, and the measurements of target chondrocytes are difficult to perform. For instance, the application of growth factors to chondrocytes in alginate as recombinant peptides (PDGF) [306] or in the form of genetic sequences (FGF-2, IGF-I), delivered via nonviral gene vectors as single sequences $[145,307]$ or in combination [308], promoted effective cartilage repair in rabbit osteochondral defects for at least $14 \mathrm{wk}$, with enhanced levels of cell proliferation and of PG and type-II collagen deposition in vivo. Additionally, hypoxia [309] and hyperbaric 
oxygen [306] were reported to significantly increase total PG and type-II collagen deposition in encapsulated chondrocytes in vivo.

\subsection{Overview and Limitations}

Overall, stimulating factors have no negative effects on cell viability, yet in certain conditions (OA/dedifferentiation), cell viability under specific stimulation may decline with time. For differentiated chondrocytes, few stimulation factors (OP-1) have positive effects on both cell proliferation and ECM deposition (PGs, type-II collagen), regardless of the cell numbers, but only short-term findings are available thus far. Under suitable stimulation, ECM deposition and/or cell proliferation may be promoted in alginate gel, although the duration of these effects may not be maintained over time to achieve adapted, permanent cartilage regeneration.

\section{Alginate and Progenitor Cells for Articular Cartilage Regeneration}

Progenitor cells, such as mesenchymal stromal cells (MSCs), have further been manipulated as a naturally chondro-reparative source of cells capable of developing a chondrocyte phenotype (morphology, cell viability, ECM deposition) [8] via entrapment in alginate as a means to improve the processes of cartilage regeneration [310,311]. Recently, dental pulp stem cells (DPSCs) also gained interest as an alternative source of chondrogenically competent progenitor cells for cartilage repair [312]. Induced pluripotent stem cells (iPSCs) represent another attractive source of progenitor cells for cartilage tissue engineering [313,314] that may also be generated from human OA chondrocytes [315]. Interestingly, the transfection of iPSCs using a lentivirus-TGF- $\beta 1$ construct [315], co-cultured with chondrocytes $[315,316]$, promoted the chondrogenic differentiation of iPSCs using an alginate matrix.

\subsection{In Vitro Studies: Differentiation after Encapsulation}

The chondrogenic differentiation of progenitor cells is induced by interactions between alginate and the cells in vitro [8,89], and may be further induced by the culture (chondrogenic) medium as well as by a number of growth factors (IGF-I, TGF- $\beta 1 /-\beta 2 /-\beta 3$, BMP-2/-7) [317-322], low-intensity ultrasounds [323], platelet-rich concentrate [324-326], and by a combination of such factors. The viability of progenitor cells in alginate increases early on in culture and then decreases over time [324], possibly due to a switch towards phenotype differentiation in the whole differentiating cell population. The mRNA expression of PGs and type-II collagen is detectable over the whole period of culture (ds 2 [8]/6 [321]/14 [323]/21 [322,325]/28) [313] with increases at the end of the period of culture (ds 14 [320]/21 [327]/24) [319,324], regardless of the cell numbers. Type-I collagen synthesis may increase [320] or not [322] in the presence or absence of BMP-2, respectively, regardless of the cell numbers [318,320,322]. Type- $X$ collagen synthesis $[322,324]$ and deposition [318] occurs with an increase over time in culture, regardless of the cell numbers. Overall, while progenitor cells in alginate commit towards the chondrocyte phenotype, they ultimately enter hypertrophic differentiation and endochondral ossification as the final form of differentiation after encapsulation (Table 7) $[8,313,314,316,318-330]$. 
Table 7. Alginate-progenitor cell systems in vitro (differentiation after encapsulation) and in vivo (encapsulation after differentiation)

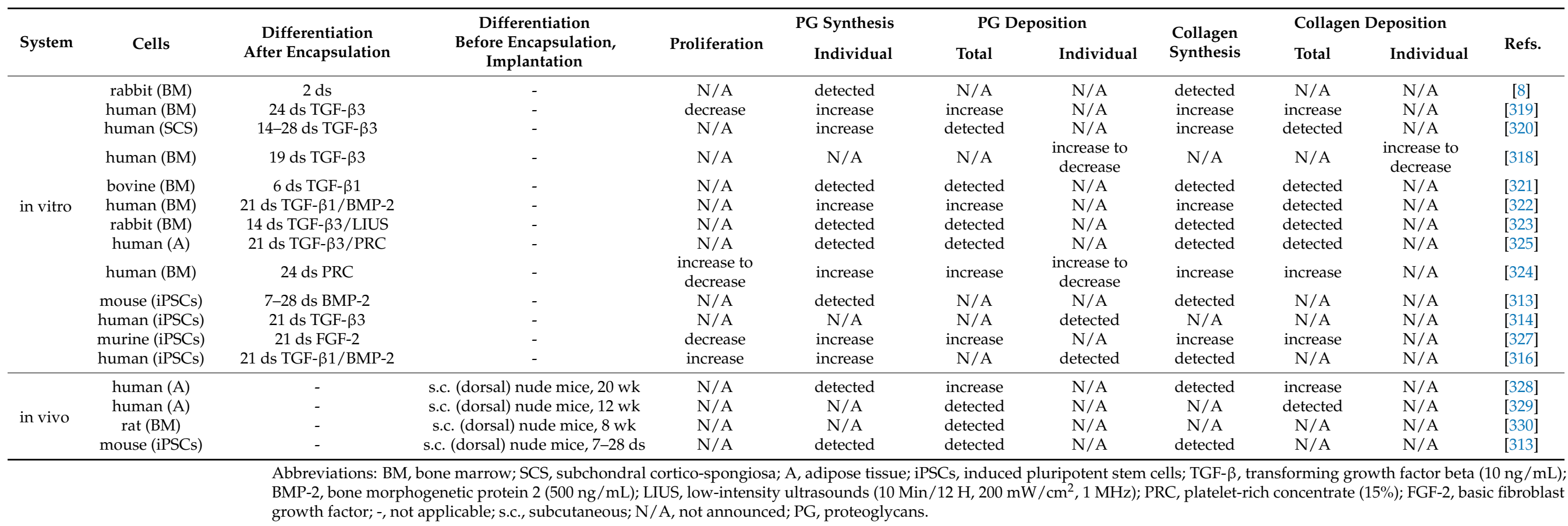




\subsection{In Vivo Studies: Encapsulation after Differentiation}

In vivo, cells undergo the mRNA expression of PGs and type-II collagen with an increase over time depending on the number of cells provided [328]. Interestingly, while type-I and type- $X$ collagen synthesis occurs at the level of individual cells [328], the deposition of these markers for total cells remains stable at a low level, without sign of dedifferentiation or transdifferentiation (Table 7).

\subsection{Overview and Limitations}

Overall, the outcomes achieved using progenitor cells in alginate in terms of effective cartilage regeneration parallel those supported when using chondrocytes [331-338]. Again, however, the adapted cartilage regeneration processes are not sufficiently addressed with either of these sources of cells to support the long-term healing of this tissue. Genetic enhancement appears to be a potent, emerging approach to amplify the outcomes for lasting regeneration [145] and to promote the spatial and temporal control of cartilage regeneration.

\section{Alginate Combined with Gene Therapy for Articular Cartilage Regeneration}

Gene therapy is an attractive approach that uses genes to prevent or cure diseases, and gene therapy for articular cartilage regeneration is based on the overexpression of chondro-reparative agents, such as growth or transcription factors, or of molecules that may impede joint destruction via gene delivery vectors [5].

Nonviral vectors (plasmids, cationic liposomes, peptides, DNA-ligand complexes, gene-gun systems) [5,32,339] as well as viral vectors (adenoviral vectors, herpes simplex virus (HSV) vectors, retroviral vectors, lentiviral vectors, recombinant adeno-associated viral (rAAV) vectors) [108,110,340] have been employed as gene transporters for the exogenous expression of therapeutics to improve cartilage regeneration.

The strategies developed to combine gene therapy with the use of alginate thus far include the encapsulation of genetically modified cells in alginate (indirect, cell-associated approach) $[5,68,145]$ and the formulation of gene transfer vectors in alginate (direct, cell-free approach) (Figure 6) [5,341-345].

a

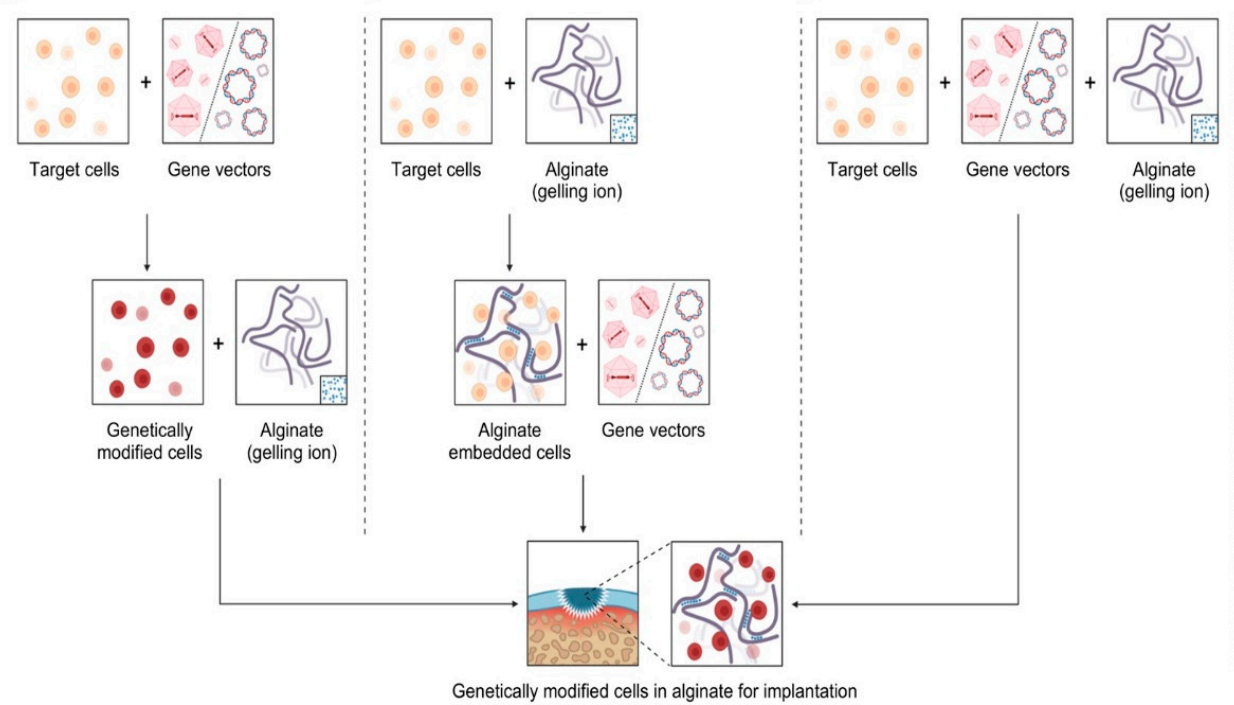

d

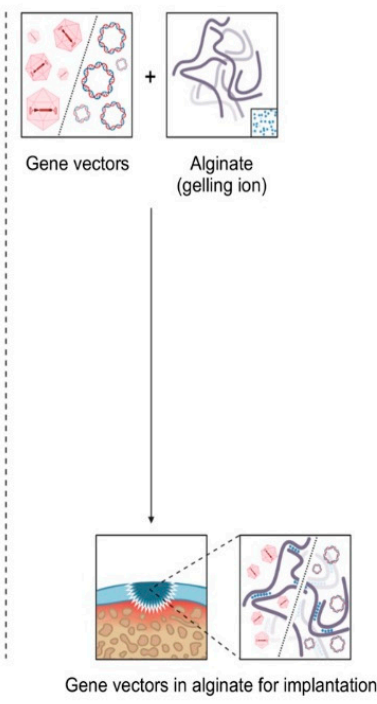

Figure 6. Strategies using gene therapy combined with alginate for articular cartilage regeneration. The approaches include $(\mathbf{a}-\mathbf{c})$ the indirect, cell-associated encapsulation of genetically modified cells in alginate and (d) the direct, cell-free formulation of gene transfer vectors in alginate, both as potential implantable platforms in articular cartilage defects. (a) Genetic modification before alginate encapsulation [68]. (b) Genetic modification after alginate encapsulation [343]. (c) Genetic modification with alginate encapsulation (gene-activated matrix) [344,345]. (d) Gene vectors with alginate encapsulation [342]. Created with BioRender.com. 


\subsection{Indirect Encapsulation of Genetically Modified Cells in Alginate}

Articular chondrocytes that are genetically modified via nonviral vectors to overexpress IGF-I or FGF-2 $[68,145,341,346]$ and then embedded in alginate undergo significant, continuous increases in cell proliferation, especially when applying IGF-I (Table 8) $[145,341,346]$. Upon IGF-I overexpression, an increase in total PG deposition is observed after 3/14 wk in vivo without the modification of the total deposition of type-II collagen [145], while type-II collagen and PG deposition increases at variable levels upon FGF-2 overexpression [68], in agreement with the effects of these growth factors $[268,270]$. Related results are noted when applying alginate with genetically modified progenitor cells from the bone marrow or from the adipose tissue upon the adenoviral or lentiviral gene transfer of IGF-I [346] or TGF- $\beta[146,347,348]$, leading to the deposition of PGs and type-II collagen (Table 8 ).

Table 8. Alginate combined with gene therapy.

\begin{tabular}{|c|c|c|c|c|c|c|c|c|}
\hline Approach & Vector & Gene & Cells & Evaluation & Proliferation & $\begin{array}{l}\text { PG Depo- } \\
\text { sition }\end{array}$ & $\begin{array}{c}\text { Collagen } \\
\text { Deposition }\end{array}$ & Refs. \\
\hline \multirow{8}{*}{$\begin{array}{l}\text { genetically } \\
\text { modified } \\
\text { cells } \\
\text { in alginate }\end{array}$} & \multirow{4}{*}{ nonviral } & \multirow[t]{2}{*}{ IGF-I } & \multirow{2}{*}{$\begin{array}{c}\text { rabbit } \\
\text { chondrocytes } \\
\text { rabbit } \\
\text { chondrocytes }\end{array}$} & in vitro, $36 \mathrm{ds}$ & increase & $\mathrm{N} / \mathrm{A}$ & $\mathrm{N} / \mathrm{A}$ & {$[145]$} \\
\hline & & & & $\begin{array}{c}\text { in vivo (OCD } \\
\text { implantation), } 14 \mathrm{wk}\end{array}$ & $\mathrm{N} / \mathrm{A}$ & increase & slight effect & {$[145]$} \\
\hline & & \multirow[t]{2}{*}{ FGF-2 } & \multirow{2}{*}{$\begin{array}{c}\text { rabbit } \\
\text { chondrocytes } \\
\text { rabbit } \\
\text { chondrocytes }\end{array}$} & & increase & $\begin{array}{c}\text { slight } \\
\text { decrease }\end{array}$ & $\mathrm{N} / \mathrm{A}$ & {$[68]$} \\
\hline & & & & $\begin{array}{c}\text { in vivo (OCD } \\
\text { implantation), 3/14 wk }\end{array}$ & $\mathrm{N} / \mathrm{A}$ & increase & increase & {$[68]$} \\
\hline & \multirow{3}{*}{ adenoviral } & IGF-I & ovine ASCs & in vitro, $28 \mathrm{ds}$ & $\mathrm{N} / \mathrm{A}$ & detected & detected & [346] \\
\hline & & TGF- $\beta 1$ & rat MSCs & in vitro, $10 \mathrm{ds}$ & $\mathrm{N} / \mathrm{A}$ & detected & detected & [347] \\
\hline & & TGF- $\beta 2$ & human ASCs & $\begin{array}{c}\text { in vivo (s.c. } \\
\text { implantation), } 4 / 12 \mathrm{wk}\end{array}$ & $\mathrm{N} / \mathrm{A}$ & detected & detected & {$[146]$} \\
\hline & lentiviral & TGF- $\beta 1$ & rat MSCs & $\begin{array}{c}\text { in vivo (CD } \\
\text { implantation), } 4 / 8 \mathrm{wk}\end{array}$ & $\mathrm{N} / \mathrm{A}$ & detected & detected & [348] \\
\hline \multirow{2}{*}{$\begin{array}{l}\text { gene transfer } \\
\text { vectorsin } \\
\text { alginate }\end{array}$} & \multirow[b]{2}{*}{ rAAV } & lacZ & human MSCs & in vitro, $21 \mathrm{ds}$ & $\mathrm{N} / \mathrm{A}$ & not altered & not altered & [341] \\
\hline & & IGF-I & - & $\begin{array}{c}\text { in vivo (CD } \\
\text { implantation), } 1 \mathrm{yr}\end{array}$ & increase & increase & increase & [341] \\
\hline
\end{tabular}

Abbreviations: rAAV, recombinant adeno-associated virus (vector); IGF-I, insulin-like growth factor I; FGF-2, basic fibroblast growth factor; TGF- $\beta$, transforming growth factor beta; lacZ, Escherichia coli $\beta$-galactosidase gene; ASCs, adipose-derived stromal cells (progenitors); MSCs, mesenchymal stromal cells (progenitors); -, not applicable; OCD, osteochondral defect; s.c., subcutaneous; $C D$, chondral defect; N/A, not announced; PG, proteoglycans.

\subsection{Direct Formulation of Gene Transfer Vectors in Alginate}

The delivery of gene transfer vectors via alginate (scaffold-guided gene transfer) has been first attempted using reporter gene constructs, such as coding for the Escherichia coli $\beta$-galactosidase (lacZ) marker gene (Table 8) [341]. In this work, the viability of MSCs in vitro was not impaired when using an rAAV-lacZ formulated in alginate, as expected with a reporter gene. The treatment also did not alter the deposition of PGs and type-II collagen in MSCs, showing the safety of the approach [341].

Recently, the application of alginate formulating an rAAV vector carrying the therapeutic IGF-I gene within sites of chondral defects led to significant increases in the levels of local cell proliferation in the lesions as well as in the deposition of PGs and type-II collagen over an extended period of one yr in vivo without deleterious (toxic, immunogenic) responses to the treatment (Table 8) [342].

It remains to be seen, however, whether such a therapeutic alginate-rAAV composite system can further improve cartilage regeneration over much longer periods of time and whether the mechanical functions in the repair tissue of the treated lesions will be restored to those of the natural, hyaline cartilage.

Such an approach nevertheless shows the high value of using alginate in combination with gene therapy to improve the processes of cartilage regeneration especially in settings in vivo. 


\section{Emerging Alginate Systems with Improved Mechanical Properties for Articular Cartilage Regeneration}

While alginate has been previously regarded as a compound lacking sufficient mechanical strength to support adapted cartilage regeneration, work has been performed and advances were accomplished to overcome this limitation for in vivo and clinical applications [116,136,164,326,346,349-379].

With this goal, alginate was either chemically modified or engineered (sulfhydrylation, alkylation, dopamine modification) $[349,354,359,361,376]$ or combined with other materials or compounds in order to generate mechanically stronger composite systems adapted for cartilage engineering [116,326,346,350-353,355-358,360,362-365,369-372,379].

Materials and compounds used to form composites with alginate include collagen [116,352], PRP [326], bovine cartilage matrix [346], agarose [352], polyvinyl alcohol (PVA) [364], poly $(\varepsilon-$ caprolactone) (PCL) [365], N,O-carboxymethyl chitosan/polyphosphate (N,O-CMC-polyP) [363], polyacrylamide (PAAm) [355,362,365], poly(L-lactic acid) (PLLA) [371], hyaluronic acid (HA) [360], polymethacrylate (PMA) [350], nanocellulose [351,358,379], poly(2-ethyl-2oxazoline) (PEOXA) [351], chondroitin sulfate [357], polyethylene glycol (PEG) with fibrin [370], and chitosan [353,356].

Overall, the mechanical properties of the expanded alginate hydrogels reported in these composites were adapted to those of the articular cartilage and often stronger than when using alginate alone $[136,164,366-368,373,375,377,378]$, especially in cell-associated experimental conditions in vitro and in vivo for improved cartilage formation [116,366,376,379].

Such upgraded systems, however, will need to be further assessed for their benefits in translational models in vivo, while they may be also investigated in approaches combined with gene therapy.

\section{Conclusions and Perspectives}

In light of the abundant literature on the competent application of alginate, this compound represents a promising biomaterial in approaches that aim to enhance articular cartilage regeneration [342] besides other (natural or synthetic) hydrogel materials (chitosan, hyaluronic acid, chondroitin sulfate, collagen, fibrin, gelatin, poly(lactide-co-glycolide), polyethylene glycol, poly( $\mathrm{N}$-isopropylacrylamide-coacrylic acid, etc.) extensively described elsewhere [119] and also used for this purpose, although to a prospectively more limited extent [119].

The use of alginate combined with a controlled chondro-reparative gene delivery system may further improve the healing responses of injured articular cartilage at the site of damage as off-the-shelf systems for therapy. However, a number of challenges remain to be addressed when using this material for such a purpose.

First, the presence of certain charged polyanions in alginate [27] may promote the formation of an abnormal collagen ultrastructure, termed segment-long-spacing (SLS)-like crystallites, in the ECM of chondrogenic cultures [380-384].

Second, cells may insufficiently adhere to the surrounding alginate, leading to impaired cell viability, proliferation, ECM deposition, and differentiation $[113,385]$. The incorporation of additional compounds (calcium phosphate [127], lactose-modified chitosan) [356] and the modification of alginate (arginine-glycine-aspartic acid, i.e., RGD) [386] may address these issues, leading to hybrid hydrogels with improved mechanical properties and supporting a better cell phenotype [162,387], and creating a more suitable surface for RGD-mediated cell attachment via the integrins ( $\alpha 5 \beta 1$ and $\alpha 5 \beta 3$ integrins) [388] found on chondrocytes and progenitor cells (Figure 7) [389,390].

Finally, the use of alginate may lead to the generation of a fibrous tissue (fibrocartilage) composed of type-I collagen instead of a natural hyaline cartilage with type-II collagen [97,391]. This might be partly addressed by using ultra-purified alginate (UPAL alginate) and ultra-purified low endotoxin alginate (UPLE alginate) [295]. 


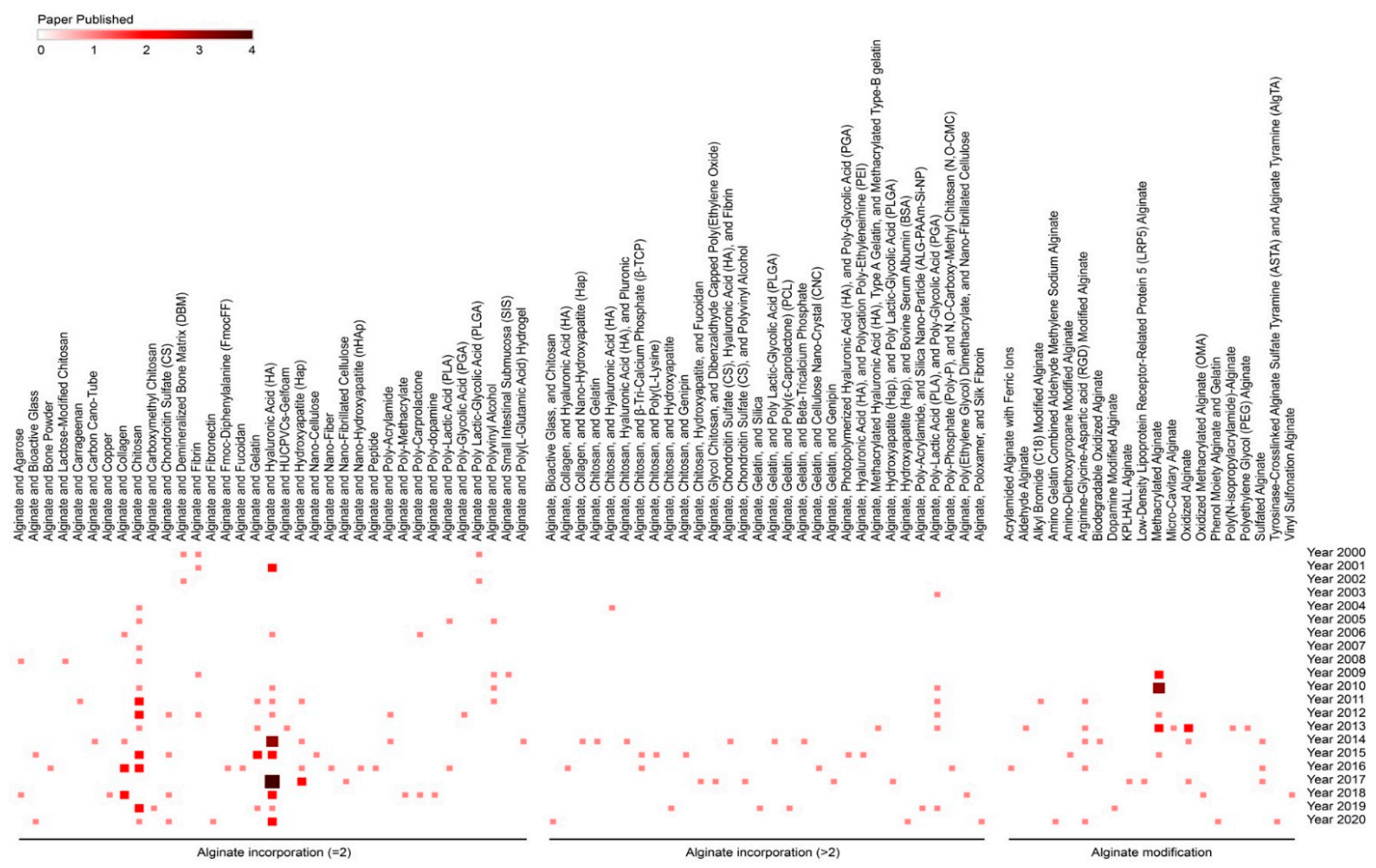

Figure 7. Enhanced cell adhesion with alginate incorporation and alginate modification (yearly distribution of the number of publications); created with Morpheus.

Other approaches to tackle these issues include the use of co-culture systems in alginate (chondrocytes/progenitor cells) [392-394] and of 3D printing techniques with multi-material incorporation [379,395,396] or alginate modification [397,398], as performed in the presence $[379,395]$ or absence $[352,399]$ of cells with nanofibrillated cellulose (NFC) $[379,396,400]$ and PCL $[395,401,402]$.

All these novel concepts may as well be combined with gene vector delivery using optimally identified chondro-reparative genes as single entities or as simultaneous genetic treatments to achieve optimal effects in cartilage regeneration (Figure 8).

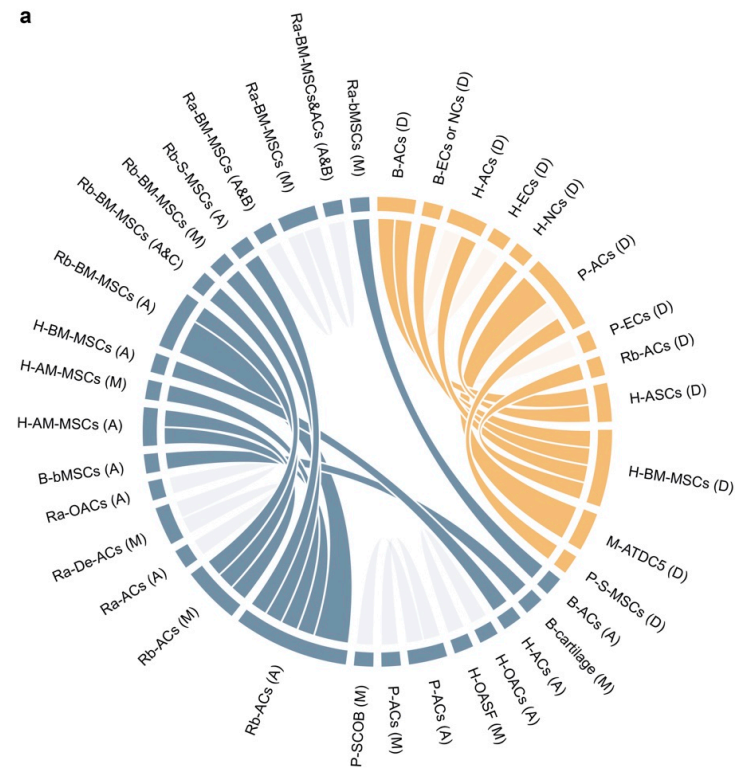

Figure 8. Cont. 


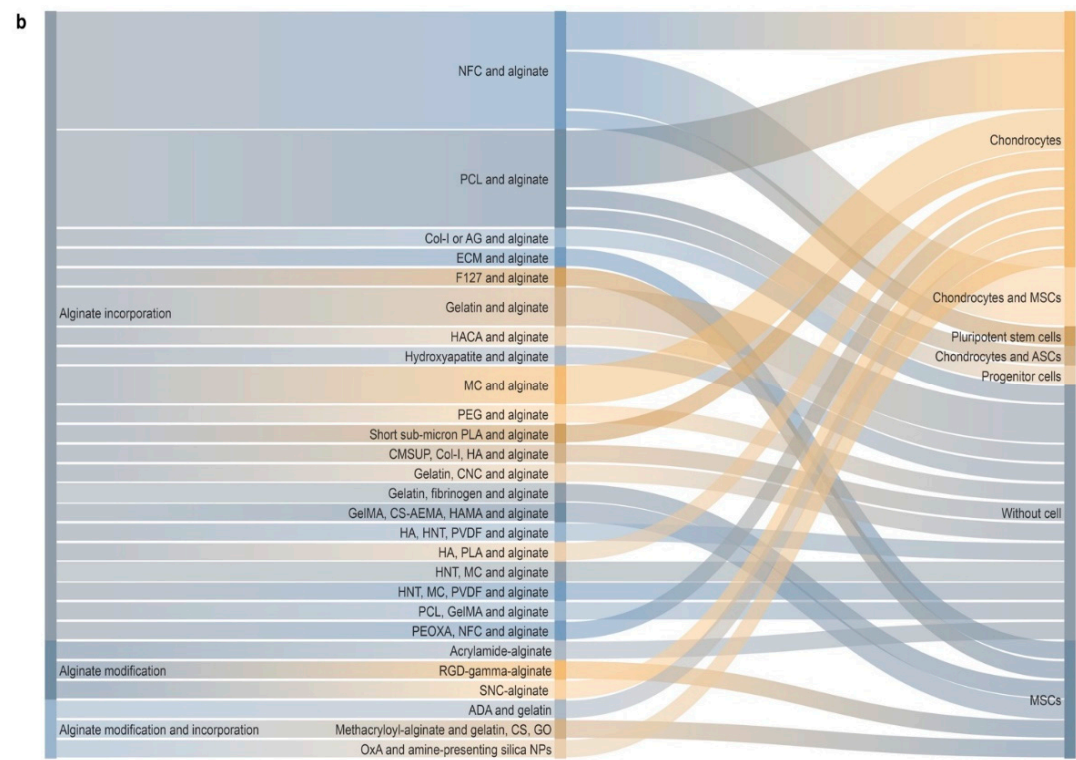

Figure 8. Co-culture systems and 3D printing techniques. (a) Co-culture systems using alginate. The orange part presents cells mixed, encapsulated in alginate, and then maintained in culture. The blue part presents cells encapsulated in alginate, mixed, and then maintained in culture. The deep cords show combinations of chondrocytes and progenitor cells $(\mathrm{A})$ in alginate, $(\mathrm{M})$ in monolayer, $(\mathrm{C})$ in collagen, (B) in bioglass, and (D) in direct contact (ACs, articular chondrocytes; AM-, amniotic membrane; B-, bovine; BM-, bone marrow; bMSCs, bone marrow mesenchymal stromal cells; Cartilage, zonal cartilage tissue; De-ACs, dedifferentiated articular chondrocytes; H-, human; MSCs, mesenchymal stromal cells; OACs, osteoarthritic articular chondrocytes; OASF, osteoarthritic synovial fibroblasts; $\mathrm{P}-$, porcine; Ra-, rat; Rb-, rabbit; S-, synovium; SCOB, subchondral osteoblasts). (b) Use of alginate as a bioink in 3D printing (ADA, alginate-di-aldehyde; AG, agarose; Alginate SNC, alginate sulfate nano-cellulose; ASCs, adipose-derived stromal cells (progenitors); CMSUP, calcium-magnesium silicate ultrafine particles; CNC, cellulose nanocrystals; Col-I, type-I collagen; CS, chondroitin sulfate; CS-AEMA, chondroitin sulfate amino ethyl methacrylate; ECM, extracellular matrix; F127, Pluronic F127; GelMA, gelatin methacrylamide; GO, graphene oxide; HA, hyaluronate; HACA, catechol modified hyaluronic acid; HAMA, hyaluronic acid methacrylate; HNT, halloysite nanotube; MC, methyl cellulose; MSCs, mesenchymal stromal cells; NFC, nanofibrillated cellulose; NPs, nanoparticles; OxA, oxidized alginate; PCL, polycaprolactone; PEG, poly(ethylene glycol); PEOXA, poly(2-ethyl-2-oxazoline); PLA, polylactic acid; PVDF, polyvinylidene fluoride; RGD-gamma-alginate, gamma-irradiated alginate with RGD peptides); created with Flourish.

Overall, the exploitation of alginate in the field of cartilage tissue engineering is progressing towards mimicking the natural in vivo microenvironment for improved treatments in patients in a close future.

Author Contributions: Conceptualization, W.L. and M.C.; validation, W.L., H.M. and M.C.; investigation, W.L. and M.C.; data curation, W.L. and M.C.; writing-original draft preparation, W.L. and M.C.; writing-review and editing, W.L., H.M. and M.C.; visualization, W.L., H.M. and M.C.; supervision, M.C.; funding acquisition, H.M. and M.C. All authors have read and agreed to the published version of the manuscript.

Funding: This research was funded by the World Arthrosis Organization (Deutsche Arthrose-Hilfe e.V. to H.M. and M.C.), by the State Scholarship Foundation (China Scholarship Council to W.L.), and by the Saarland University within the funding program Open Access Publishing.

Conflicts of Interest: The authors declare no conflict of interest. 


\section{References}

1. Hafezi, M.; Khorasani, S.N.; Zare, M.; Neisiany, R.E.; Davoodi, P. Advanced Hydrogels for Cartilage Tissue Engineering: Recent Progress and Future Directions. Polymers 2021, 13, 4199. [CrossRef] [PubMed]

2. $\quad$ von der Mark, K.; Gauss, V.; von der Mark, H.; Muller, P. Relationship between cell shape and type of collagen synthesised as chondrocytes lose their cartilage phenotype in culture. Nature 1977, 267, 531-532. [CrossRef]

3. Benya, P.; Padilla, S.R.; Nimni, M.E. Independent regulation of collagen types by chondrocytes during the loss of differentiated function in culture. Cell 1978, 15, 1313-1321. [CrossRef]

4. Maity, C.; Das, N. Alginate-Based Smart Materials and Their Application: Recent Advances and Perspectives. Top. Curr. Chem. 2021, 380, 1-67. [CrossRef] [PubMed]

5. Buckwalter, J.A.; Mankin, H.J. Articular cartilage: Tissue design and chondrocyte-matrix interactions. Instr. Course Lect. 1998, 47, 477-486.

6. Anderson, D.E.; Johnstone, B. Dynamic Mechanical Compression of Chondrocytes for Tissue Engineering: A Critical Review. Front. Bioeng. Biotechnol. 2017, 5, 76. [CrossRef]

7. Orth, P.; Peifer, C.; Goebel, L.; Cucchiarini, M.; Madry, H. Comprehensive analysis of translational osteochondral repair: Focus on the histological assessment. Prog. Histochem. Cytochem. 2015, 50, 19-36. [CrossRef]

8. Diduch, D.R.; Jordan, L.C.; Mierisch, C.M.; Balian, G. Marrow stromal cells embedded in alginate for repair of osteochondral defects. Arthrosc. J. Arthrosc. Relat. Surg. 2000, 16, 571-577. [CrossRef]

9. Oláh, T.; Kamarul, T.; Madry, H.; Murali, M.R. The Illustrative Anatomy and the Histology of the Healthy Hyaline Cartilage. In The Illustrative Book of Cartilage Repair; Springer Science and Business Media LLC: Berlin/Heidelberg, Germany, 2021; pp. 5-10.

10. Oláh, T.; Madry, H. The osteochondral unit: The importance of the underlying subchondral bone. In Cartilage Restoration: Practical Clinical Applications; Farr, J., Gomoll, A.H., Eds.; Springer International Publishing: Cham, Switzerland, 2018 ; pp. 13-22.

11. Nelson, L.; McCarthy, H.E.; Fairclough, J.; Williams, R.; Archer, C.W. Evidence of a viable pool of stcm Cells within human osteoarthritic cartilage. Cartilage 2014, 5, 203-214. [CrossRef]

12. Dowthwaite, G.P.; Bishop, J.C.; Redman, S.N.; Khan, I.M.; Rooney, P.; Evans, D.J.R.; Haughton, L.; Bayram, Z.; Boyer, S.; Thomson, B.; et al. The surface of articular cartilage contains a progenitor cell population. J. Cell Sci. 2004, 117, 889-897. [CrossRef]

13. Fellows, C.R.; Williams, R.; Davies, I.R.; Gohil, K.; Baird, D.; Fairclough, J.; Rooney, P.; Archer, C.W.; Khan, I.M. Characterisation of a divergent progenitor cell sub-populations in human osteoarthritic cartilage: The role of telomere erosion and replicative senescence. Sci. Rep. 2017, 7, 41421. [CrossRef] [PubMed]

14. Williams, R.; Khan, I.M.; Richardson, K.; Nelson, L.; McCarthy, H.E.; Analbelsi, T.; Singhrao, S.K.; Dowthwaite, G.P.; Jones, R.E.; Baird, D.M.; et al. Identification and Clonal Characterisation of a Progenitor Cell Sub-Population in Normal Human Articular Cartilage. PLoS ONE 2010, 5, e13246. [CrossRef] [PubMed]

15. Coates, E.; Fisher, J.P. Gene expression of alginate-embedded chondrocyte subpopulations and their response to exogenous IGF-1 delivery. J. Tissue Eng. Regen. Med. 2011, 6, 179-192. [CrossRef] [PubMed]

16. Guilak, F.; Nims, R.J.; Dicks, A.; Wu, C.-L.; Meulenbelt, I. Osteoarthritis as a disease of the cartilage pericellular matrix. Matrix Biol. 2018, 71-72, 40-50. [CrossRef] [PubMed]

17. Wilusz, R.E.; Sanchez-Adams, J.; Guilak, F. The structure and function of the pericellular matrix of articular cartilage. Matrix Biol. 2014, 39, 25-32. [CrossRef]

18. Demoor-Fossard, M.; Redini, F.; Boittin, M.; Pujol, J.-P. Expression of decorin and biglycan by rabbit articular chondrocytes. Biochim. Et Biophys. Acta (BBA)-Gene Struct. Expr. 1998, 1398, 179-191. [CrossRef]

19. van Osch, G.J.; van den Berg, W.B.; Hunziker, E.B.; Hauselmann, H.J. Differential effects of IGF-1 and TGF beta-2 on the assembly of proteoglycans in pericellular and territorial matrix by cultured bovine articular chondrocytes. Osteoarthr. Cartil. 1998, 6, 187-195. [CrossRef]

20. Ragan, P.M.; Chin, V.I.; Hung, H.-H.K.; Masuda, K.; Thonar, E.J.-M.; Arner, E.C.; Grodzinsky, A.J.; Sandy, J.D. Chondrocyte Extracellular Matrix Synthesis and Turnover Are Influenced by Static Compression in a New Alginate Disk Culture System. Arch. Biochem. Biophys. 2000, 383, 256-264. [CrossRef]

21. Caron, M.M.J.; Emans, P.J.; Coolsen, M.M.E.; Voss, L.; Surtel, D.A.M.; Cremers, A.; van Rhijn, L.W.; Welting, T.J.M. Redifferentiation of dedifferentiated human articular chondrocytes: Comparison of 2D and 3D cultures. Osteoarthr. Cartil. 2012, 20, 1170-1178. [CrossRef]

22. Platt, D.; Wells, T.; Bayliss, M. Proteoglycan metabolism of equine articular chondrocytes cultured in alginate beads. Res. Vet.-Sci. 1997, 62, 39-47. [CrossRef]

23. Hauselmann, H.; Fernandes, R.; Mok, S.; Schmid, T.; Block, J.; Aydelotte, M.; Kuettner, K.; Thonar, E. Phenotypic stability of bovine articular chondrocytes after long-term culture in alginate beads. J. Cell Sci. 1994, 107, 17-27. [CrossRef] [PubMed]

24. Grogan, S.P.; Chen, X.; Sovani, S.; Taniguchi, N.; ColwellJr., C.W.; Lotz, M.K.; D’Lima, D.D. Influence of Cartilage Extracellular Matrix Molecules on Cell Phenotype and Neocartilage Formation. Tissue Eng. Part A 2014, 20, 264-274. [CrossRef] [PubMed]

25. Liu, H.; Lee, Y.-W.; Dean, M. Re-expression of differentiated proteoglycan phenotype by dedifferentiated human chondrocytes during culture in alginate beads. Biochim. Biophys. Acta (BBA)-Gen. Subj. 1998, 1425, 505-515. [CrossRef]

26. Doege, K.J.; Sasaki, M.; Kimura, T.; Yamada, Y. Complete coding sequence and deduced primary structure of the human cartilage large aggregating proteoglycan, aggrecan. Human-specific repeats, and additional alternatively spliced forms. J. Biol. Chem. 1991, 266, 894-902. [CrossRef] 
27. Häuselmann, H.; Aydelotte, M.; Schumacher, B.; Kuettner, K.; Gitelis, S.; Thonar, E.J.-M. Synthesis and Turnover of Proteoglycans by Human and Bovine Adult Articular Chondrocytes Cultured in Alginate Beads. Matrix 1992, 12, 116-129. [CrossRef]

28. Demoor-Fossard, M.; Boittin, M.; Redini, F.; Pujol, J.P. Differential effects of interleukin-1 and transforming growth factor beta on the synthesis of small proteoglycans by rabbit articular chondrocytes cultured in alginate beads as compared to monolayers. Mol. Cell. Biochem. 1999, 199, 69-80. [CrossRef] [PubMed]

29. Kokenyesi, R.; Tan, L.; Robbins, J.R.; Goldring, M.B. Proteoglycan Production by Immortalized Human Chondrocyte Cell Lines Cultured under Conditions That Promote Expression of the Differentiated Phenotype. Arch. Biochem. Biophys. 2000, 383, 79-90. [CrossRef]

30. Kuettner, K.E. Biochemistry of articular cartilage in health and disease. Clin. Biochem. 1992, 25, 155-163. [CrossRef]

31. Newman, A.P. Articular cartilage repair. Am. J. Sports Med. 1998, 26, 309-324. [CrossRef]

32. Poole, A.R.; Kojima, T.; Yasuda, T.; Mwale, F.; Kobayashi, M.; Laverty, S. Composition and structure of articular cartilage: A template for tissue repair. Clin. Orthop. Relat. Res. 2001, 391, S26-S33. [CrossRef]

33. Gagne, T.A.; Chappell-Afonso, K.; Johnson, J.L.; McPherson, J.M.; Oldham, C.A.; Tubo, R.A.; Vaccaro, C.; Vasios, G.W. Enhanced proliferation and differentiation of human articular chondrocytes when seeded at low cell densities in alginate In Vitro. J. Orthop. Res. 2000, 18, 882-890. [CrossRef]

34. Bonaventure, J.; Kadhom, N.; Cohen-Solal, L.; Ng, K.; Bourguignon, J.; Lasselin, C.; Freisinger, P. Reexpression of CartilageSpecific Genes by Dedifferentiated Human Articular Chondrocytes Cultured in Alginate Beads. Exp. Cell Res. 1994, 212, 97-104. [CrossRef] [PubMed]

35. Beekman, B.; Verzijl, N.; A Bank, R.; Von Der Mark, K.; Tekoppele, J.M. Synthesis of Collagen by Bovine Chondrocytes Cultured in Alginate; Posttranslational Modifications and Cell-Matrix Interaction. Exp. Cell Res. 1997, 237, 135-141. [CrossRef] [PubMed]

36. Domm, C.; Schünke, M.; Steinhagen, J.; Freitag, S.; Kurz, B. Influence of Various Alginate Brands on the Redifferentiation of Dedifferentiated Bovine Articular Chondrocytes in Alginate Bead Culture under High and Low Oxygen Tension. Tissue Eng. 2004, 10, 1796-1805. [CrossRef] [PubMed]

37. Kuettner, K.E.; Aydelotte, M.B.; Thonar, E.J. Articular cartilage matrix and structure: A minireview. J. Rheumatol. Suppl. 1991, 27, $46-48$.

38. Schuurman, W.; Gawlitta, D.; Klein, T.; Hoope, W.T.; van Rijen, M.H.P.; Dhert, W.J.A.; van Weeren, P.R.; Malda, J. Zonal Chondrocyte Subpopulations Reacquire Zone-Specific Characteristics during in Vitro Redifferentiation. Am. J. Sports Med. 2009, 37, 97-104. [CrossRef] [PubMed]

39. Petit, B.; Masuda, K.; D’Souza, A.; Otten, L.; Pietryla, D.; Hartmann, D.; Morris, N.; Uebelhart, D.; Schmid, T.; Thonar, E.M. Characterization of Crosslinked Collagens Synthesized by Mature Articular Chondrocytes Cultured in Alginate Beads: Comparison of Two Distinct Matrix Compartments. Exp. Cell Res. 1996, 225, 151-161. [CrossRef] [PubMed]

40. Poole, A.R.; Pidoux, I.; Reiner, A.; Rosenberg, L. An immunoelectron microscope study of the organization of proteoglycan monomer, link protein, and collagen in the matrix of articular cartilage. J. Cell Biol. 1982, 93, 921-937. [CrossRef]

41. A Poole, C.; Glant, T.T.; Schofield, J.R. Chondrons from articular cartilage. (IV). Immunolocalization of proteoglycan epitopes in isolated canine tibial chondrons. J. Histochem. Cytochem. 1991, 39, 1175-1187. [CrossRef]

42. A Poole, C.; Ayad, S.; Gilbert, R.T. Chondrons from articular cartilage. V. Immunohistochemical evaluation of type VI collagen organisation in isolated chondrons by light, confocal and electron microscopy. J. Cell Sci. 1992, 103, 1101-1110. [CrossRef] [PubMed]

43. A Poole, C.; Ayad, S.; Schofield, J.R. Chondrons from articular cartilage: I. Immunolocalization of type VI collagen in the pericellular capsule of isolated canine tibial chondrons. J. Cell Sci. 1988, 90, 635-643. [CrossRef] [PubMed]

44. Hu, K.; Xu, L.; Cao, L.; Flahiff, C.M.; Brussiau, J.; Ho, K.; Setton, L.A.; Youn, I.; Guilak, F.; Olsen, B.R.; et al. Pathogenesis of osteoarthritis-like changes in the joints of mice deficient in type IX collagen. Arthritis Care Res. 2006, 54, 2891-2900. [CrossRef] [PubMed]

45. Poole, C.A.; Gilbert, R.T.; Herbage, D.; Hartmann, D.J. Immunolocalization of type IX collagen in normal and spontaneously osteoarthritic canine tibial cartilage and isolated chondrons. Osteoarthr. Cartil. 1997, 5, 191-204. [CrossRef]

46. Knudson, C.B. Hyaluronan receptor-directed assembly of chondrocyte pericellular matrix. J. Cell Biol. 1993, 120, 825-834. [CrossRef]

47. Kavanagh, E.; Ashhurst, D.E. Development and Aging of the Articular Cartilage of the Rabbit Knee Joint: Distribution of Biglycan, Decorin, and Matrilin-1. J. Histochem. Cytochem. 1999, 47, 1603-1615. [CrossRef]

48. Sundarraj, N.; Fite, D.; Ledbetter, S.; Chakravarti, S.; Hassell, J.R. Perlecan is a component of cartilage matrix and promotes chondrocyte attachment. J. Cell Sci. 1995, 108, 2663-2672. [CrossRef]

49. Siczkowski, M.; Watt, F.M. Subpopulations of chondrocytes from different zones of pig articular cartilage. Isolation, growth and proteoglycan synthesis in culture. J. Cell Sci. 1990, 97, 349-360. [CrossRef]

50. Vanderploeg, E.; Wilson, C.; Levenston, M. Articular chondrocytes derived from distinct tissue zones differentially respond to in vitro oscillatory tensile loading. Osteoarthr. Cartil. 2008, 16, 1228-1236. [CrossRef]

51. Wong, M.; Wuethrich, P.; Eggli, P.; Hunziker, E. Zone-specific cell biosynthetic activity in mature bovine articular cartilage: A new method using confocal microscopic stereology and quantitative autoradiography. J. Orthop. Res. 1996, 14, 424-432. [CrossRef]

52. Ulrich-Vinther, M.; Maloney, M.D.; Schwarz, E.M.; Rosier, R.; O'keefe, R.J. Articular Cartilage Biology. J. Am. Acad. Orthop. Surg. 2003, 11, 421-430. [CrossRef] 
53. Miosge, N.; Flachsbart, K.; Goetz, W.; Schultz, W.; Kresse, H.; Herken, R. Light and electron microscopical immunohistochemical localization of the small proteoglycan core proteins decorin and biglycan in human knee joint cartilage. Histochem. J. 1994, 26, 939-945. [CrossRef] [PubMed]

54. Poole, A.R.; Rosenberg, L.C.; Reiner, A.; Ionescu, M.; Bogoch, E.; Roughley, P.J. Contents and distributions of the proteoglycans decorin and biglycan in normal and osteoarthritic human articular cartilage. J. Orthop. Res. 1996, 14, 681-689. [CrossRef] [PubMed]

55. Muir, H.; Bullough, P.; Maroudas, A. The distribution of collagen in human articular cartilage with some of its physiological implications. J. Bone Jt. Surg. Br. 1970, 52, 554-563. [CrossRef]

56. Hayes, A.J.; Hall, A.; Brown, L.; Tubo, R.; Caterson, B. Macromolecular Organization and In Vitro Growth Characteristics of Scaffold-free Neocartilage Grafts. J. Histochem. Cytochem. 2007, 55, 853-866. [CrossRef]

57. Herzog, W.; Federico, S. Considerations on Joint and Articular Cartilage Mechanics. Biomech. Model. Mechanobiol. 2006,5 , 64-81. [CrossRef]

58. Yamane, S.; Cheng, E.; You, Z.; Reddi, A.H. Gene Expression Profiling of Mouse Articular and Growth Plate Cartilage. Tissue Eng. 2007, 13, 2163-2173. [CrossRef]

59. Flannery, C.R.; Hughes, C.; Schumacher, B.L.; Tudor, D.; Aydelotte, M.B.; Kuettner, K.E.; Caterson, B. Articular Cartilage Superficial Zone Protein (SZP) Is Homologous to Megakaryocyte Stimulating Factor Precursor and Is a Multifunctional Proteoglycan with Potential Growth-Promoting, Cytoprotective, and Lubricating Properties in Cartilage Metabolism. Biochem. Biophys. Res. Commun. 1999, 254, 535-541. [CrossRef]

60. Schumacher, B.; Block, J.; Schmid, T.; Aydelotte, M.; Kuettner, K. A Novel Proteoglycan Synthesized and Secreted by Chondrocytes of the Superficial Zone of Articular Cartilage. Arch. Biochem. Biophys. 1994, 311, 144-152. [CrossRef]

61. Schumacher, B.L.; Hughes, C.E.; Kuettner, K.E.; Caterson, B.; Aydelotte, M.B. Immunodetection and partial cDNA sequence of the proteoglycan, superficial zone protein, synthesized by cells lining synovial joints. J. Orthop. Res. 1999, 17, 110-120. [CrossRef]

62. Bank, R.A.; Bayliss, M.T.; Lafeber, F.P.J.G.; Maroudas, A.; Tekoppele, J.M. Ageing and zonal variation in post-translational modification of collagen in normal human articular cartilage: The age-related increase in non-enzymatic glycation affects biomechanical properties of cartilage. Biochem. J. 1998, 330, 345-351. [CrossRef]

63. Kempson, G.E.; Muir, H.; Pollard, C.; Tuke, M. The tensile properties of the cartilage of human femoral condyles related to the content of collagen and glycosaminoglycans. Biochim. Biophys. Acta BBA Gen. Subj. 1973, 297, 456-472. [CrossRef]

64. Asari, A.; Miyauchi, S.; Kuriyama, S.; Machida, A.; Kohno, K.; Uchiyama, Y. Localization of hyaluronic acid in human articular cartilage. J. Histochem. Cytochem. 1994, 42, 513-522. [CrossRef] [PubMed]

65. Maroudas, A.; Muir, H.; Wingham, J. The correlation of fixed negative charge with glycosaminoglycan content of human articular cartilage. Biochim. Biophys. Acta (BBA)-Gen. Subj. 1969, 177, 492-500. [CrossRef]

66. Dicesare, P.E.; Mörgelin, M.; Carlson, C.S.; Pasumarti, S.; Paulsson, M. Cartilage oligomeric matrix protein: Isolation and characterization from human articular cartilage. J. Orthop. Res. 1995, 13, 422-428. [CrossRef] [PubMed]

67. Bayliss, M.T.; Venn, M.; Maroudas, A.; Ali, S.Y. Structure of proteoglycans from different layers of human articular cartilage. Biochem. J. 1983, 209, 387-400. [CrossRef]

68. Stockwell, R.A. Chondrocytes. J. Clin. Pathol. Suppl. (R. Coll. Pathol.) 1978, 12, 7-13. [CrossRef]

69. Mankin, H.J. The response of articular cartilage to mechanical injury. J. Bone Jt. Surg. Am. 1982, 64, 460-466. [CrossRef]

70. Muir, H. The chondrocyte, architect of cartilage. Biomechanics, structure, function and molecular biology of cartilage matrix macromolecules. BioEssays 1995, 17, 1039-1048. [CrossRef]

71. Hall, A.C.; Horwitz, E.R.; Wilkins, R.J. The cellular physiology of articular cartilage. Exp. Physiol. 1996, 81, 535-545. [CrossRef]

72. Buckwalter, J.; Mankin, H.J. Articular cartilage repair and transplantation. Arthritis Care Res. 1998, 41, 1331-1342. [CrossRef]

73. O'Driscoll, S.W. The healing and regeneration of articular cartilage. J. Bone Jt. Surg. Am. 1998, 80, 1795-1812. [CrossRef]

74. Sally, R.F.; Frenkel, S.R.; E Di Cesare, P. Degradation and repair of articular cartilage. Front. Biosci. 1999, 4, D671-D685. [CrossRef]

75. Athanasiou, K.A.; Shah, A.R.; Hernandez, R.J.; LeBaron, R.G. Basic Science of Articular Cartilage Repair. Clin. Sports Med. 2001, 20, 223-247. [CrossRef]

76. Hunziker, E. Articular cartilage repair: Basic science and clinical progress. A review of the current status and prospects. Osteoarthr. Cartil. 2002, 10, 432-463. [CrossRef]

77. Pearle, A.D.; Warren, R.F.; Rodeo, S.A. Basic Science of Articular Cartilage and Osteoarthritis. Clin. Sports Med. 2005, 24, 1-12. [CrossRef]

78. Sophia Fox, A.J.; Bedi, A.; Rodeo, S.A. The Basic Science of Articular Cartilage: Structure, Composition, and Function. Sports Health Multidiscip. Approach 2009, 1, 461-468. [CrossRef]

79. Lemare, F.; Steimberg, N.; Le Griel, C.; Demignot, S.; Adolphe, M. Dedifferentiated chondrocytes cultured in alginate beads: Restoration of the differentiated phenotype and of the metabolic responses to interleukin-1beta. J. Cell Physiol. 1998, 176, 303-313. [CrossRef]

80. Gründer, T.; Gaissmaier, C.; Fritz, J.; Stoop, R.; Hortschansky, P.; Mollenhauer, J.; Aicher, W.K. Bone morphogenetic protein (BMP)-2 enhances the expression of type II collagen and aggrecan in chondrocytes embedded in alginate beads. Osteoarthr. Cartil. 2004, 12, 559-567. [CrossRef]

81. De Ceuninck, F.; Lesur, C.; Pastoureau, P.; Caliez, A.; Sabatini, M. Culture of Chondrocytes in Alginate Beads. Cartil. Osteoarthr. 2004, 100, 15-22. [CrossRef] 
82. Mierisch, C.M.; Wilson, H.A.; Turner, M.A.; Milbrandt, T.A.; Berthoux, L.; Hammarskjold, M.L.; Rekosh, D.; Balian, G.; Diduch, D.R. Chondrocyte transplantation into articular cartilage defects with use of calcium alginate: The fate of the cells. J. Bone Jt. Surg. Am. 2003, 85, 1757-1767. [CrossRef]

83. Grandolfo, M.; D’Andrea, P.; Paoletti, S.; Martina, M.; Silvestrini, G.; Bonucci, E.; Vittur, F. Culture and differentiation of chondrocytes entrapped in alginate gels. Calcif. Tissue Int. 1993, 52, 42-48. [CrossRef] [PubMed]

84. Van Osch, G.J.; van der Veen, S.W.; Buma, P.; Verwoerd-Verhoef, H.L. Effect of transforming growth factor-beta on proteoglycan synthesis by chondrocytes in relation to differentiation stage and the presence of pericellular matrix. Matrix Biol. 1998, 17, 413-424. [CrossRef]

85. Qin, X.; Jiang, Q.; Nagano, K.; Moriishi, T.; Miyazaki, T.; Komori, H.; Ito, K.; Von Der Mark, K.; Sakane, C.; Kaneko, H.; et al. Runx2 is essential for the transdifferentiation of chondrocytes into osteoblasts. PLoS Genet. 2020, 16, e1009169. [CrossRef] [PubMed]

86. Wolff, L.I.; Hartmann, C. A Second Career for Chondrocytes-Transformation into Osteoblasts. Curr. Osteoporos. Rep. 2019, 17, 129-137. [CrossRef]

87. Charlier, E.; Deroyer, C.; Ciregia, F.; Malaise, O.; Neuville, S.; Plener, Z.; Malaise, M.; de Seny, D. Chondrocyte dedifferentiation and osteoarthritis (OA). Biochem. Pharmacol. 2019, 165, 49-65. [CrossRef]

88. Sandell, L.J.; Aigner, T. Articular cartilage and changes in arthritis. An introduction: Cell biology of osteoarthritis. Arthritis Res. 2001, 3, 107-113. [CrossRef]

89. Shakibaei, M.; Souza, P. Differentiation of Mesenchymal Limb Bud Cells to Chondrocytes in Alginate Beads. Cell Biol. Int. 1997, 21, 75-86. [CrossRef]

90. Hayashi, M.; Ninomiya, Y.; Parsons, J.; Hayashi, K.; Olsen, B.R.; Trelstad, R.L. Differential localization of mRNAs of collagen types I and II in chick fibroblasts, chondrocytes, and corneal cells by in situ hybridization using cDNA probes. J. Cell Biol. 1986, 102, 2302-2309. [CrossRef]

91. Von der Mark, H.; von der Mark, K.; Gay, S. Study of differential collagen synthesis during development of the chick embryo by immunofluorescence. I. Preparation of collagen type I and type II specific antibodies and their application to early stages of the chick embryo. Dev. Biol. 1976, 48, 237-249. [CrossRef]

92. Colowick, N.P.; Kaplan, N.P.; Cunningham, L.W. Extracellular matrix. In Structural and Contractile Proteins, 1st ed.; Cunningham, L.W., Ed.; Academic Press: Orlando, FL, USA, 1987; Volume 144, pp. 1-561.

93. Mhanna, R.; Öztürk, E.; Schlink, P.; Zenobi-Wong, M. Probing the microenvironmental conditions for induction of superficial zone protein expression. Osteoarthr. Cartil. 2013, 21, 1924-1932. [CrossRef]

94. Binette, F.; McQuaid, D.P.; Haudenschild, D.R.; Yaeger, P.C.; McPherson, J.M.; Tubo, R. Expression of a stable articular cartilage phenotype without evidence of hypertrophy by adult human articular chondrocytes in vitro. J. Orthop. Res. 1998, 16, 207-216. [CrossRef] [PubMed]

95. Loty, S.; Sautier, J.-M.; Loty, C.; Boulekbache, H.; Kokubo, T.; Forest, N. Cartilage formation by fetal rat chondrocytes cultured in alginate beads: A proposed model for investigating tissue-biomaterial interactions. J. Biomed. Mater. Res. 1998, 42, 213-222. [CrossRef]

96. Darling, E.; Athanasiou, K.A. Rapid phenotypic changes in passaged articular chondrocyte subpopulations. J. Orthop. Res. 2005, 23, 425-432. [CrossRef] [PubMed]

97. Jonitz, A.; Lochner, K.; Peters, K.; Salamon, A.; Pasold, J.; Mueller-Hilke, B.; Hansmann, D.; Bader, R. Differentiation Capacity of Human Chondrocytes Embedded in Alginate Matrix. Connect. Tissue Res. 2011, 52, 503-511. [CrossRef]

98. Hicks, D.L.; Sage, A.B.; Shelton, E.; Schumacher, B.L.; Sah, R.L.; Watson, D. Effect of bone morphogenetic proteins 2 and 7 on septal chondrocytes in alginate. Otolaryngol. Neck Surg. 2007, 136, 373-379. [CrossRef]

99. Takahashi, N.; Knudson, C.B.; Thankamony, S.; Ariyoshi, W.; Mellor, L.; Im, H.-J.; Knudson, W. Induction of CD44 cleavage in articular chondrocytes. Arthritis Rheum. 2010, 62, 1338-1348. [CrossRef]

100. Bauge, C.; Duval, E.; Ollitrault, D.; Girard, N.; Leclercq, S.; Galera, P.; Boumediene, K. Type II TGFbeta receptor modulates chondrocyte phenotype. Age 2013, 35, 1105-1116. [CrossRef]

101. Cooke, M.E.; Pearson, M.J.; Moakes, R.J.A.; Weston, C.J.; Davis, E.T.; Jones, S.W.; Grover, L.M. Geometric confinement is required for recovery and maintenance of chondrocyte phenotype in alginate. APL Bioeng. 2017, 1, 016104. [CrossRef]

102. Hauselmann, H.J.; Masuda, K.; Hunziker, E.B.; Neidhart, M.; Mok, S.S.; Michel, B.A.; Thonar, E.J. Adult human chondrocytes cultured in alginate form a matrix similar to native human articular cartilage. Am. J. Physiol. Physiol. 1996, 271, C742-C752. [CrossRef]

103. Heiligenstein, S.; Cucchiarini, M.; Laschke, M.W.; Bohle, R.M.; Kohn, D.; Menger, M.; Madry, H. In vitro and in vivo characterization of non-biomedical and biomedical grade alginates for articular chondrocyte transplantation. Tissue Eng. Part C Methods 2011, 17, 829-842. [CrossRef]

104. Widuchowski, W.; Trzaska, T. Articular cartilage defects: Study of 25,124 knee arthroscopies. Knee 2007, 14, 177-182. [CrossRef] [PubMed]

105. Mankin, H.J. The reaction of articular cartilage to injury and osteoarthritis (first of two parts). N. Engl. J. Med. 1974, 291, 1285-1292. [CrossRef] [PubMed]

106. A Buckwalter, J.; Brown, T.D. Joint injury, repair, and remodeling: Roles in post-traumatic osteoarthritis. Clin. Orthop. Relat. Res. 2004, 423, 7-16. [CrossRef] 
107. Madry, H.; van Dijk, C.N.; Mueller-Gerbl, M. The basic science of the subchondral bone. Knee Surg. Sports Traumatol. Arthrosc. 2010, 18, 419-433. [CrossRef]

108. Madry, H.; Grun, U.W.; Knutsen, G. Cartilage repair and joint preservation: Medical and surgical treatment options. Dtsch. Arztebl. Int. 2011, 108, 669-677.

109. Jiang, S.; Guo, W.; Tian, G.; Luo, X.; Peng, L.; Liu, S.; Sui, X.; Guo, Q.; Li, X. Clinical Application Status of Articular Cartilage Regeneration Techniques: Tissue-Engineered Cartilage Brings New Hope. Stem Cells Int. 2020, 2020, 5690252. [CrossRef]

110. Cucchiarini, M.; Madry, H. Use of Tissue Engineering Strategies to Repair Joint Tissues in Osteoarthritis: Viral Gene Transfer Approaches. Curr. Rheumatol. Rep. 2014, 16, 1-9. [CrossRef]

111. Welton, K.L.; Logterman, S.; Bartley, J.H.; Vidal, A.F.; McCarty, E.C. Knee Cartilage Repair and Restoration: Common Problems and Solutions. Clin. Sports Med. 2018, 37, 307-330. [CrossRef]

112. Loredo, G.; Koolpe, M.; Benton, H. Influence of Alginate Polysaccharide Composition and Culture Conditions on Chondrocytes in Three-Dimensional Culture. Tissue Eng. 1996, 2, 115-125. [CrossRef]

113. Li, L.; Yu, F.; Zheng, L.; Wang, R.; Yan, W.; Wang, Z.; Xu, J.; Wu, J.; Shi, D.; Zhu, L.; et al. Natural hydrogels for cartilage regeneration: Modification, preparation and application. J. Orthop. Transl. 2019, 17, 26-41. [CrossRef]

114. Van Susante, J.L.; Buma, P.; van Osch, G.J.; Versleyen, D.; van der Kraan, P.M.; van der Berg, W.B.; Homminga, G.N. Culture of chondrocytes in alginate and collagen carrier gels. Acta Orthop. Scand 1995, 66, 549-556. [CrossRef]

115. Saltz, A.; Kandalam, U. Mesenchymal stem cells and alginate microcarriers for craniofacial bone tissue engineering: A review. J. Biomed. Mater. Res. Part A 2016, 104, 1276-1284. [CrossRef] [PubMed]

116. Yang, X.; Guo, L.; Fan, Y.; Zhang, X. Preparation and characterization of macromolecule cross-linked collagen hydrogels for chondrocyte delivery. Int. J. Biol. Macromol. 2013, 61, 487-493. [CrossRef] [PubMed]

117. Sun, J.; Tan, H. Alginate-Based Biomaterials for Regenerative Medicine Applications. Materials 2013, 6, 1285-1309. [CrossRef] [PubMed]

118. Homicz, M.R.; Chia, S.H.; Schumacher, B.L.; Masuda, K.; Thonar, E.J.; Sah, R.L.; Watson, D. Human Septal Chondrocyte Redifferentiation in Alginate, Polyglycolic Acid Scaffold, and Monolayer Culture. Laryngoscope 2003, 113, 25-32. [CrossRef]

119. Madry, H.; Rey-Rico, A.; Venkatesan, J.K.; Johnstone, B.; Cucchiarini, M. Transforming Growth Factor Beta-Releasing Scaffolds for Cartilage Tissue Engineering. Tissue Eng. Part B Rev. 2014, 20, 106-125. [CrossRef]

120. Paige, K.T.; Vacanti, C.A. Engineering New Tissue: Formation of Neo-Cartilage. Tissue Eng. 1995, 1, 97-106. [CrossRef]

121. Gaumann, A.; Laudes, M.; Jacob, B.; Pommersheim, R.; Laue, C.; Vogt, W.; Schrezenmeir, J. Effect of media composition on long-term in vitro stability of barium alginate and polyacrylic acid multilayer microcapsules. Biomaterials 2000, 21, 1911-1917. [CrossRef]

122. Khan, F.; Ahmad, S.R. Polysaccharides and Their Derivatives for Versatile Tissue Engineering Application. Macromol. Biosci. 2013, 13, 395-421. [CrossRef]

123. Chen, K.L.; Mylon, A.S.E.; Elimelech, M. Enhanced Aggregation of Alginate-Coated Iron Oxide (Hematite) Nanoparticles in the Presence of Calcium, Strontium, and Barium Cations. Langmuir 2007, 23, 5920-5928. [CrossRef]

124. DeRamos, C.; Irwin, A.; Nauss, J.; Stout, B. 13C NMR and molecular modeling studies of alginic acid binding with alkaline earth and lanthanide metal ions. Inorganica Chim. Acta 1997, 256, 69-75. [CrossRef]

125. Wang, L.; Shelton, R.; Cooper, P.; Lawson, M.; Triffitt, J.; Barralet, J. Evaluation of sodium alginate for bone marrow cell tissue engineering. Biomaterials 2003, 24, 3475-3481. [CrossRef]

126. Wong, M. Alginates in Tissue Engineering. Biopolym. Methods Tissue Eng. 2003, 238, 77-86. [CrossRef]

127. Tı̆̆lı, R.S.; Gümüşderelioğlu, M. Evaluation of alginate-chitosan semi IPNs as cartilage scaffolds. J. Mater. Sci. Mater. Med. 2008, 20, 699-709. [CrossRef]

128. Abbah, S.A.; Lu, W.W.; Peng, S.L.; Aladin, D.M.K.; Li, Z.Y.; Tam, W.K.; Cheung, K.M.C.; Luk, K.D.K.; Zhou, G.-Q. Extracellular Matrix Stability of Primary Mammalian Chondrocytes and Intervertebral Disc Cells Cultured in Alginate-Based Microbead Hydrogels. Cell Transplant. 2008, 17, 1181-1192. [CrossRef]

129. Wong, M.; Siegrist, M.; Wang, X.; Hunziker, E. Development of mechanically stable alginate/chondrocyte constructs: Effects of guluronic acid content and matrix synthesis. J. Orthop. Res. 2001, 19, 493-499. [CrossRef]

130. Knight, M.; Bravenboer, J.V.D.B.; Lee, D.; van Osch, G.; Weinans, H.; Bader, D. Cell and nucleus deformation in compressed chondrocyte-alginate constructs: Temporal changes and calculation of cell modulus. Biochim. Biophys. Acta (BBA)-Gen. Subj. 2002, 1570, 1-8. [CrossRef]

131. Focaroli, S.; Teti, G.; Salvatore, V.; Orienti, I.; Falconi, M. Calcium/Cobalt Alginate Beads as Functional Scaffolds for Cartilage Tissue Engineering. Stem Cells Int. 2016, 2016, 2030478. [CrossRef]

132. Goh, C.H.; Heng, P.W.S.; Chan, L.W. Alginates as a useful natural polymer for microencapsulation and therapeutic applications. Carbohydr. Polym. 2012, 88, 1-12. [CrossRef]

133. Park, H.; Kang, S.-W.; Kim, B.-S.; Mooney, D.J.; Lee, K.Y. Shear-reversibly Crosslinked Alginate Hydrogels for Tissue Engineering. Macromol. Biosci. 2009, 9, 895-901. [CrossRef]

134. Hunt, N.; Grover, L.M. Cell encapsulation using biopolymer gels for regenerative medicine. Biotechnol. Lett. 2010, 32, 733-742. [CrossRef] [PubMed] 
135. Dornish, M.; Kaplan, D.; Skaugrud, O. Standards and guidelines for biopolymers in tissue-engineered medical products: ASTM alginate and chitosan standard guides. American Society for Testing and Materials. Ann. N. Y. Acad. Sci. 2001, 944, 388-397. [CrossRef] [PubMed]

136. Enobakhare, B.; Bader, D.L.; Lee, D. Concentration and M/G ratio influence the physiochemical and mechanical properties of alginate constructs for tissue engineering. J. Appl. Biomater. Biomech. 2006, 4, 87-96. [PubMed]

137. Andrade, L.R.; Arcanjo, K.D.S.; Martins, H.S.H.; dos Reis, J.S.N.; Farina, M.; Borojevic, R.; Duarte, M.E.L. Fine structure and molecular content of human chondrocytes encapsulated in alginate beads. Cell Biol. Int. 2011, 35, 293-297. [CrossRef] [PubMed]

138. Paige, K.T.; Cima, L.G.; Yaremchuk, M.J.; Schloo, B.L.; Vacanti, J.P.; Vacanti, C.A. De Novo Cartilage Generation Using Calcium Alginate-Chondrocyte Constructs. Plast. Reconstr. Surg. 1996, 97, 168-178. [CrossRef] [PubMed]

139. Jang, J.; Seol, Y.-J.; Kim, H.J.; Kundu, J.; Kim, S.W.; Cho, D.-W. Effects of alginate hydrogel cross-linking density on mechanical and biological behaviors for tissue engineering. J. Mech. Behav. Biomed. Mater. 2014, 37, 69-77. [CrossRef]

140. Guo, J.; Jourdian, G.W.; Maccallum, D.K. Culture and Growth Characteristics of Chondrocytes Encapsulated in Alginate Beads. Connect. Tissue Res. 1989, 19, 277-297. [CrossRef]

141. Samuel, S.; Ahmad, R.E.; Ramasamy, T.S.; Manan, F.; Kamarul, T. Platelet rich concentrate enhances mesenchymal stem cells capacity to repair focal cartilage injury in rabbits. Injury 2018, 49, 775-783. [CrossRef]

142. Marijnissen, W.J.; van Osch, G.J.; Aigner, J.; van der Veen, S.W.; Hollander, A.P.; Verwoerd-Verhoef, H.L.; Verhaar, J. Alginate as a chondrocyte-delivery substance in combination with a non-woven scaffold for cartilage tissue engineering. Biomaterials 2002, 23 , 1511-1517. [CrossRef]

143. Cohen, S.B.; Meirisch, C.M.; Wilson, H.A.; Diduch, D.R. The use of absorbable co-polymer pads with alginate and cells for articular cartilage repair in rabbits. Biomaterials 2003, 24, 2653-2660. [CrossRef]

144. Madry, H.; Cucchiarini, M.; Stein, U.; Remberger, K.; Menger, M.D.; Kohn, D.; Trippel, S.B. Sustained transgene expression in cartilage defects in vivo after transplantation of articular chondrocytes modified by lipid-mediated gene transfer in a gel suspension delivery system. J. Gene Med. 2003, 5, 502-509. [CrossRef] [PubMed]

145. Madry, H.; Kaul, G.; Cucchiarini, M.; Stein, U.; Zurakowski, D.; Remberger, K.; Menger, M.D.; Kohn, D.; Trippel, S.B. Enhanced repair of articular cartilage defects in vivo by transplanted chondrocytes overexpressing insulin-like growth factor I (IGF-I). Gene Ther. 2005, 12, 1171-1179. [CrossRef]

146. Jin, X.B.; Sun, Y.S.; Zhang, K.; Wang, J.; Shi, T.P.; Ju, X.D.; Lou, S.Q. Ectopic neocartilage formation from predifferentiated human adipose derived stem cells induced by adenoviral-mediated transfer of hTGF beta2. Biomaterials 2007, 28, 2994-3003. [CrossRef]

147. Hwang, N.S.; Varghese, S.; Elisseeff, J. Cartilage tissue engineering: Directed differentiation of embryonic stem cells in threedimensional hydrogel culture. Methods Mol. Biol. 2007, 407, 351-373. [PubMed]

148. Varshney, R.R.; Zhou, R.; Hao, J.; Yeo, S.S.; Chooi, W.H.; Fan, J.; Wang, D.-A. Chondrogenesis of synovium-derived mesenchymal stem cells in gene-transferred co-culture system. Biomaterials 2010, 31, 6876-6891. [CrossRef] [PubMed]

149. Chuang, C.Y.; Shahin, K.; Lord, M.S.; Melrose, J.; Doran, P.M.; Whitelock, J.M. The cartilage matrix molecule components produced by human foetal cartilage rudiment cells within scaffolds and the role of exogenous growth factors. Biomaterials $\mathbf{2 0 1 2}$ 33, 4078-4088. [CrossRef] [PubMed]

150. Ren, L.; Feng, X.; Ma, D.; Chen, F.; Ding, Y. Mechanical properties of alginate hydrogels with different concentrations and their effects on the proliferation chondrocytes in vitro. Sheng Wu Yi Xue Gong Cheng Xue Za Zhi 2012, 29, 884-888.

151. Wang, Y.; De Isla, N.; Decot, V.; Marchal, L.; Cauchois, G.; Huselstein, C.; Muller, S.; Wang, B.; Netter, P.; Stoltz, J. Influences of construct properties on the proliferation and matrix synthesis of dedifferentiated chondrocytes cultured in alginate gel. Biomaterials 2008, 45, 527-538. [CrossRef]

152. Zhang, W.; Xia, Y.; Ling, Y.; Yang, W.; Dong, Z.-X.; Wang, D.-A.; Fan, C. A Transcriptome Sequencing Study on Genome-Wide Gene Expression Differences of 3D Cultured Chondrocytes in Hydrogel Scaffolds with Different Gel Density. Macromol. Biosci. 2020, 20, e2000028. [CrossRef]

153. Bouhadir, K.H.; Lee, K.Y.; Alsberg, E.; Damm, K.L.; Anderson, K.W.; Mooney, D.J. Degradation of Partially Oxidized Alginate and Its Potential Application for Tissue Engineering. Biotechnol. Prog. 2001, 17, 945-950. [CrossRef]

154. Strand, B.L.; Morch, Y.A.; Skjak-Braek, G. Alginate as immobilization matrix for cells. Minerva Biotecnol. $2000,12,223-233$.

155. Ishikawa, K.; Ueyama, Y.; Mano, T.; Koyama, T.; Suzuki, K.; Matsumura, T. Self-setting barrier membrane for guided tissue regeneration method: Initial evaluation of alginate membrane made with sodium alginate and calcium chloride aqueous solutions. J. Biomed. Mater. Res. 1999, 47, 111-115. [CrossRef]

156. Matthew, I.R.; Browne, R.M.; Frame, J.W.; Millar, B.G. Subperiosteal behaviour of alginate and cellulose wound dressing materials. Biomaterials 1995, 16, 275-278. [CrossRef]

157. Wu, S.; Suzuki, Y.; Tanihara, M.; Ohnishi, K.; Endo, K.; Nishimura, Y. Repair of facial nerve with alginate sponge without suturing: An experimental study in cats. Scand. J. Plast. Reconstr. Surg. Hand Surg. 2002, 36, 135-140. [CrossRef] [PubMed]

158. Wan, L.Q.; Jiang, J.; Arnold, D.E.; Guo, X.E.; Lu, H.H.; Mow, V.C. Calcium Concentration Effects on the Mechanical and Biochemical Properties of Chondrocyte-Alginate Constructs. Cell. Mol. Bioeng. 2008, 1, 93-102. [CrossRef]

159. Cohen, J.; Zaleski, K.L.; Nourissat, G.; Julien, T.P.; Randolph, M.A.; Yaremchuk, M.J. Survival of porcine mesenchymal stem cells over the alginate recovered cellular method. J. Biomed. Mater. Res. Part A 2010, 96A, 93-99. [CrossRef] 
160. Aydelotte, M.B.; Thonar, E.J.M.A.; Mollenhauer, J.; Flechtenmacher, J. Culture of chondrocytes in alginate gel: Variations in conditions of Gelation influence the structure of the alginate gel, and the arrangement and morphology of proliferating chondrocytes. Vitr. Cell. Dev. Biol.-Anim. 1998, 34, 123-130. [CrossRef] [PubMed]

161. Drury, J.L.; Dennis, R.G.; Mooney, D.J. The tensile properties of alginate hydrogels. Biomaterials 2004, 25, 3187-3199. [CrossRef] [PubMed]

162. Perka, C.; Spitzer, R.S.; Lindenhayn, K.; Sittinger, M.; Schultz, O. Matrix-mixed culture: New methodology for chondrocyte culture and preparation of cartilage transplants. J. Biomed. Mater. Res. 2000, 49, 305-311. [CrossRef]

163. Momma, D.; Onodera, T.; Kawamura, D.; Urita, A.; Matsui, Y.; Baba, R.; Funakoshi, T.; Kondo, M.; Endo, T.; Kondo, E.; et al. Acellular Cartilage Repair Technique Based on Ultrapurified Alginate Gel Implantation for Advanced Capitellar Osteochondritis Dissecans. Orthop. J. Sports Med. 2021, 9, 2325967121989676. [CrossRef]

164. Williams, G.M.; Klein, T.J.; Sah, R.L. Cell density alters matrix accumulation in two distinct fractions and the mechanical integrity of alginate-chondrocyte constructs. Acta Biomater. 2005, 1, 625-633. [CrossRef] [PubMed]

165. Lee, H.J.; Choi, B.H.; Min, B.-H.; Park, S.R. Low-Intensity Ultrasound Inhibits Apoptosis and Enhances Viability of Human Mesenchymal Stem Cells in Three-Dimensional Alginate Culture during Chondrogenic Differentiation. Tissue Eng. 2007, 13, 1049-1057. [CrossRef] [PubMed]

166. Wang, C.-C.; Yang, K.-C.; Lin, K.-H.; Liu, Y.-L.; Liu, H.-C.; Lin, F.-H. Cartilage regeneration in SCID mice using a highly organized three-dimensional alginate scaffold. Biomaterials 2012, 33, 120-127. [CrossRef] [PubMed]

167. Wang, C.-C.; Yang, K.-C.; Lin, K.-H.; Liu, H.-C.; Lin, F.-H. A highly organized three-dimensional alginate scaffold for cartilage tissue engineering prepared by microfluidic technology. Biomaterials 2011, 32, 7118-7126. [CrossRef]

168. Mahmoudi, Z.; Mohammadnejad, J.; Razavi Bazaz, S.; Abouei Mehrizi, A.; Saidijam, M.; Dinarvand, R.; Ebrahimi Warkiani, M.; Soleimani, M. Promoted chondrogenesis of hMCSs with controlled release of TGF-beta3 via microfluidics synthesized alginate nanogels. Carbohydr. Polym. 2020, 229, 115551. [CrossRef]

169. Petrenko, Y.A.; Ivanov, R.V.; Petrenko, A.; Lozinsky, V.I. Coupling of gelatin to inner surfaces of pore walls in spongy alginatebased scaffolds facilitates the adhesion, growth and differentiation of human bone marrow mesenchymal stromal cells. J. Mater. Sci. Mater. Med. 2011, 22, 1529-1540. [CrossRef]

170. Strand, B.L.; Mørch, Y.; Espevik, T.; Skjåk-BraeK, G. Visualization of alginate-poly-L-lysine-alginate microcapsules by confocal laser scanning microscopy. Biotechnol. Bioeng. 2003, 82, 386-394. [CrossRef]

171. Tamponnet, C.; Ramdi, H.; Guyot, J.-B.; Lièvremont, M. Rabbit articular chondrocytes in alginate gel: Characterisation of immobilized preparations and potential applications. Appl. Microbiol. Biotechnol. 1992, 37, 311-315. [CrossRef]

172. Ewa-Choy, Y.W.; Pingguan-Murphy, B.; Abdul-Ghani, N.A.; Jahendran, J.; Chua, K.H. Effect of alginate concentration on chondrogenesis of co-cultured human adipose-derived stem cells and nasal chondrocytes: A biological study. Biomater. Res. 2017, 21, 19. [CrossRef]

173. Larsen, B.E.; Bjørnstad, J.; Pettersen, E.O.; Tønnesen, H.H.; Melvik, J.E. Rheological characterization of an injectable alginate gel system. BMC Biotechnol. 2015, 15, 1-12. [CrossRef]

174. Ghert, M.A.; Jung, S.T.; Qi, W.-N.; Harrelson, J.M.; Erickson, H.P.; Block, J.; Scully, S.P. The Clinical Significance of Tenascin-C Splice Variant Expression in Chondrosarcoma. Oncology 2001, 61, 306-314. [CrossRef] [PubMed]

175. Pleumeekers, M.M.; Nimeskern, L.; Koevoet, W.L.; Kops, N.; Poublon, R.M.; Stok, K.S.; van Osch, G.J. The in vitro and in vivo capacity of culture-expanded human cells from several sources encapsulated in alginate to form cartilage. Eur. Cell Mater. 2014, 27, 264-280; discussion 278-280. [CrossRef] [PubMed]

176. Smith, G.N.; Albrecht, M.; Mickler, E.A. Effects of Misoprostol and Salicylate on Canine Osteoarthritis. Am. J. Ther. 1996, 3, 17-20. [CrossRef] [PubMed]

177. Choi, S.; Kim, J.-H.; Ha, J.; Jeong, B.-I.; Jung, Y.C.; Lee, G.-S.; Woo, H.-M.; Kang, B.-J. Intra-Articular Injection of AlginateMicroencapsulated Adipose Tissue-Derived Mesenchymal Stem Cells for the Treatment of Osteoarthritis in Rabbits. Stem Cells Int. 2018, 2018, 2791632. [CrossRef]

178. Kobayashi, S.; Meir, A.; Urban, J. Effect of cell density on the rate of glycosaminoglycan accumulation by disc and cartilage cells in vitro. J. Orthop. Res. 2008, 26, 493-503. [CrossRef]

179. Alexander, T.H.; Sage, A.B.; Schumacher, B.L.; Sah, R.L.; Watson, D. Human serum for tissue engineering of human nasal septal cartilage. Otolaryngol. Neck Surg. 2006, 135, 397-403. [CrossRef]

180. Heywood, H.K.; Bader, D.L.; Lee, D.A. Glucose Concentration and Medium Volume Influences Cell Viability and Glycosaminoglycan Synthesis in Chondrocyte-Seeded Alginate Constructs. Tissue Eng. 2006, 12, 3487-3496. [CrossRef]

181. Guo, H.; Torzilli, P.A. Shape of chondrocytes within articular cartilage affects the solid but not the fluid microenvironment under unconfined compression. Acta Biomater. 2016, 29, 170-179. [CrossRef]

182. Poole, C.A. Review. Articular cartilage chondrons: Form, function and failure. J. Anat. 1997, 191 Pt 1, 1-13. [CrossRef]

183. Ramdi, H.; Jouti, M.A.T.; Lievremont, M. Immobilized Articular Chondrocytes: In Vitro Production of Extracellular Matrix Compounds. Biomater. Artif. Cells Immobil. Biotechnol. 1993, 21, 335-341. [CrossRef]

184. Loeser, R.F.; Shanker, G. Autocrine stimulation by insulin-like growth factor 1 and insulin-like growth factor 2 mediates chondrocyte survival in vitro. Arthritis Rheum. 2000, 43, 1552-1559. [CrossRef] 
185. Loeser, R.F.; Pacione, C.A.; Chubinskaya, S. The combination of insulin-like growth factor 1 and osteogenic protein 1 promotes increased survival of and matrix synthesis by normal and osteoarthritic human articular chondrocytes. Arthritis Rheum. 2003, 48, 2188-2196. [CrossRef] [PubMed]

186. Mouw, J.; Case, N.; Guldberg, R.; Plaas, A.; Levenston, M. Variations in matrix composition and GAG fine structure among scaffolds for cartilage tissue engineering. Osteoarthr. Cartil. 2005, 13, 828-836. [CrossRef] [PubMed]

187. Lin, Y.-J.; Yen, C.-N.; Hu, Y.-C.; Wu, Y.-C.; Liao, C.-J.; Chu, I.-M. Chondrocytes culture in three-dimensional porous alginate scaffolds enhanced cell proliferation, matrix synthesis and gene expression. J. Biomed. Mater. Res. Part A 2009, 88A, 23-33. [CrossRef] [PubMed]

188. Eslaminejad, M.B.; Taghiyar, L.; Falahi, F. Quantitative analysis of the proliferation and differentiation of rat articular chondrocytes in alginate 3D culture. Iran. Biomed. J. 2009, 13, 153-160.

189. Mok, S.S.; Masuda, K.; Hauselmann, H.J.; Aydelotte, M.B.; Thonar, E.J. Aggrecan synthesized by mature bovine chondrocytes suspended in alginate. Identification of two distinct metabolic matrix pools. J. Biol. Chem. 1994, 269, 33021-33027. [CrossRef]

190. Ab-Rahim, S.; Selvaratnam, L.; Raghavendran, H.R.; Kamarul, T. Chondrocyte-alginate constructs with or without TGF-beta1 produces superior extracellular matrix expression than monolayer cultures. Mol. Cell. Biochem. 2013, 376, 11-20. [CrossRef]

191. Knudson, C.B.; Knudson, W. Hyaluronan-binding proteins in development, tissue homeostasis, and disease. FASEB J. 1993, 7 , 1233-1241. [CrossRef]

192. Knudson, W.; Knudson, C.B. Assembly of a chondrocyte-like pericellular matrix on non-chondrogenic cells. Role of the cell surface hyaluronan receptors in the assembly of a pericellular matrix. J. Cell Sci. 1991, 99, 227-235. [CrossRef]

193. Nishida, Y.; Knudson, C.; Kuettner, K.; Knudson, W. Osteogenic protein-1 promotes the synthesis and retention of extracellular matrix within bovine articular cartilage and chondrocyte cultures. Osteoarthr. Cartil. 2000, 8, 127-136. [CrossRef]

194. Chubinskaya, S.; Huch, K.; Schulze, M.; Otten, L.; Aydelotte, M.B.; Cole, A.A. Gene Expression by Human Articular Chondrocytes Cultured in Alginate Beads. J. Histochem. Cytochem. 2001, 49, 1211-1219. [CrossRef] [PubMed]

195. Tanaka, H.; Matsumura, M.; Veliky, I.A. Diffusion characteristics of substrates in Ca-alginate gel beads. Biotechnol. Bioeng. 1984, 26, 53-58. [CrossRef] [PubMed]

196. Aurich, M.; Hofmann, G.O.; Gras, F.; Rolauffs, B. Human osteochondritis dissecans fragment-derived chondrocyte characteristics ex vivo, after monolayer expansion-induced de-differentiation, and after re-differentiation in alginate bead culture. BMC Musculoskelet. Disord. 2018, 19, 168. [CrossRef] [PubMed]

197. Eyre, D.R.; Oguchi, H. The hydroxypyridinium crosslinks of skeletal collagens: Their measurement, properties and a proposed pathway of formation. Biochem. Biophys. Res. Commun. 1980, 92, 403-410. [CrossRef]

198. Wu, J.-J.; Eyre, D.R. Cartilage type IX collagen is cross-linked by hydroxypyridinium residues. Biochem. Biophys. Res. Commun. 1984, 123, 1033-1039. [CrossRef]

199. Bastiaansen-Jenniskens, Y.M.; Koevoet, W.; Feijt, C.; Bos, P.K.; Verhaar, J.A.N.; Van Osch, G.J.V.M.; DeGroot, J. Proteoglycan production is required in initial stages of new cartilage matrix formation but inhibits integrative cartilage repair. J. Tissue Eng. Regen. Med. 2009, 3, 117-123. [CrossRef]

200. Maroudas, A.; Palla, G.; Gilav, E. Racemization of Aspartic Acid in Human Articular Cartilage. Connect. Tissue Res. 1992, 28, 161-169. [CrossRef]

201. Hsieh-Bonassera, N.D.; Wu, I.; Lin, J.K.; Schumacher, B.L.; Chen, A.C.; Masuda, K.; Bugbee, W.D.; Sah, R.L. Expansion and Redifferentiation of Chondrocytes from Osteoarthritic Cartilage: Cells for Human Cartilage Tissue Engineering. Tissue Eng. Part A 2009, 15, 3513-3523. [CrossRef]

202. Yoon, Y.-M.; Kim, S.-J.; Oh, C.-D.; Ju, J.-W.; Song, W.K.; Yoo, Y.J.; Huh, T.-L.; Chun, J.-S. Maintenance of Differentiated Phenotype of Articular Chondrocytes by Protein Kinase C and Extracellular Signal-regulated Protein Kinase. J. Biol. Chem. 2002, 277, 8412-8420. [CrossRef]

203. Murphy, C.L.; Sambanis, A. Effect of Oxygen Tension and Alginate Encapsulation on Restoration of the Differentiated Phenotype of Passaged Chondrocytes. Tissue Eng. 2001, 7, 791-803. [CrossRef]

204. Wiseman, M.; Bader, D.L.; Reisler, T.; A Lee, D. Passage in monolayer influences the response of chondrocytes to dynamic compression. Biorheology 2004, 41, 283-298.

205. Schulze-Tanzil, G.; Mobasheri, A.; de Souza, P.; John, T.; Shakibaei, M. Loss of chondrogenic potential in dedifferentiated chondrocytes correlates with deficient Shc-Erk interaction and apoptosis. Osteoarthr. Cartil. 2004, 12, 448-458. [CrossRef] [PubMed]

206. Zaucke, F.; Dinser, R.; Maurer, P.; Paulsson, M. Cartilage oligomeric matrix protein (COMP) and collagen IX are sensitive markers for the differentiation state of articular primary chondrocytes. Biochem. J. 2001, 358 Pt 1, 17-24. [CrossRef] [PubMed]

207. Carossino, A.M.; Recenti, R.; Carossino, R.; Piscitelli, E.; Gozzini, A.; Martineti, V.; Mavilia, C.; Franchi, A.; Danielli, D.; Aglietti, P.; et al. Methodological models for in vitro amplification and maintenance of human articular chondrocytes from elderly patients. Biogerontology 2007, 8, 483-498. [CrossRef] [PubMed]

208. Boubriak, O.; Brooks, J.; Urban, J. Cytochrome c oxidase levels in chondrocytes during monolayer expansion and after return to three dimensional culture. Osteoarthr. Cartil. 2009, 17, 1084-1092. [CrossRef]

209. Mandl, E.W.; van der Veen, S.W.; Verhaar, J.A.; van Osch, G.J. Multiplication of human chondrocytes with low seeding densities accelerates cell yield without losing redifferentiation capacity. Tissue Eng. 2004, 10, 109-118. [CrossRef] 
210. Tay, L.X.; Ahmad, R.E.; Dashtdar, H.; Tay, K.; Masjuddin, T.; Ab-Rahim, S.; Chong, P.-P.; Selvaratnam, L.; Kamarul, T. Treatment Outcomes of Alginate-Embedded Allogenic Mesenchymal Stem Cells Versus Autologous Chondrocytes for the Repair of Focal Articular Cartilage Defects in a Rabbit Model. Am. J. Sports Med. 2011, 40, 83-90. [CrossRef]

211. Heiligenstein, S.; Cucchiarini, M.; Laschke, M.W.; Bohle, R.M.; Kohn, D.; Menger, M.D.; Madry, H. Evaluation of nonbiomedical and biomedical grade alginates for the transplantation of genetically modified articular chondrocytes to cartilage defects in a large animal model in vivo. J. Gene Med. 2011, 13, 230-242. [CrossRef]

212. Zeng, L.; Chen, X.; Zhang, Q.; Yu, F.; Li, Y.; Yao, Y. Redifferentiation of dedifferentiated chondrocytes in a novel three-dimensional microcavitary hydrogel. J. Biomed. Mater. Res. Part A 2014, 103, 1693-1702. [CrossRef]

213. Akaraphutiporn, E.; Sunaga, T.; Bwalya, E.C.; Echigo, R.; Okumura, M. Alterations in characteristics of canine articular chondrocytes in non-passaged long-term monolayer culture: Matter of differentiation, dedifferentiation and redifferentiation. J. Vet.-Med. Sci. 2020, 82, 793-803. [CrossRef]

214. Angelozzi, M.; Penolazzi, L.; Mazzitelli, S.; Lambertini, E.; Lolli, A.; Piva, R.; Nastruzzi, C. Dedifferentiated Chondrocytes in Composite Microfibers As Tool for Cartilage Repair. Front. Bioeng. Biotechnol. 2017, 5, 35. [CrossRef] [PubMed]

215. Bianchi, V.J.; Lee, A.; Anderson, J.; Parreno, J.; Theodoropoulos, J.; Backstein, D.; Kandel, R. Redifferentiated Chondrocytes in Fibrin Gel for the Repair of Articular Cartilage Lesions. Am. J. Sports Med. 2019, 47, 2348-2359. [CrossRef] [PubMed]

216. Bianchi, V.J.; Weber, J.F.; Waldman, S.D.; Backstein, D.; Kandel, R.A. Formation of Hyaline Cartilage Tissue by Passaged Human Osteoarthritic Chondrocytes. Tissue Eng. Part A 2017, 23, 156-165. [CrossRef] [PubMed]

217. Das, R.; Timur, U.T.; Edip, S.; Haak, E.; Wruck, C.; Weinans, H.; Jahr, H. TGF-beta2 is involved in the preservation of the chondrocyte phenotype under hypoxic conditions. Ann. Anat. 2015, 198, 1-10. [CrossRef] [PubMed]

218. Domm, C.; Fay, J.; Schunke, M.; Kurz, B. Redifferentiation of dedifferentiated joint cartilage cells in alginate culture. Effect of intermittent hydrostatic pressure and low oxygen partial pressure. Orthopade 2000, 29, 91-99. [PubMed]

219. Domm, C.; Schünke, M.; Christesen, K.; Kurz, B. Redifferentiation of dedifferentiated bovine articular chondrocytes in alginate culture under low oxygen tension. Osteoarthr. Cartil. 2002, 10, 13-22. [CrossRef]

220. Duval, E.; Leclercq, S.; Elissalde, J.-M.; Demoor, M.; Galéra, P.; Boumédiene, K. Hypoxia-inducible factor $1 \alpha$ inhibits the fibroblastlike markers type I and type III collagen during hypoxia-induced chondrocyte redifferentiation: Hypoxia not only induces type II collagen and aggrecan, but it also inhibits type I and type III collagen in the hypoxia-inducible factor $1 \alpha$-dependent redifferentiation of chondrocytes. Arthritis Rheum. 2009, 60, 3038-3048. [CrossRef]

221. Hamamoto, S.; Chijimatsu, R.; Shimomura, K.; Kobayashi, M.; Jacob, G.; Yano, F.; Saito, T.; Chung, U.-I.; Tanaka, S.; Nakamura, N. Enhancement of chondrogenic differentiation supplemented by a novel small compound for chondrocyte-based tissue engineering. J. Exp. Orthop. 2020, 7, 1-14. [CrossRef]

222. Heyland, J.; Wiegandt, K.; Goepfert, C.; Nagel-Heyer, S.; Ilinich, E.; Schumacher, U.; Pörtner, R. Redifferentiation of chondrocytes and cartilage formation under intermittent hydrostatic pressure. Biotechnol. Lett. 2006, 28, 1641-1648. [CrossRef]

223. Huang, X.; Zhong, L.; Hendriks, J.; Post, J.N.; Karperien, M. Different response of human chondrocytes from healthy looking areas and damaged regions to IL1beta stimulation under different oxygen tension. J. Orthop. Res. 2019, 37, 84-93. [CrossRef]

224. Huang, X.; Zhong, L.; Post, J.N.; Karperien, M. Co-treatment of TGF-beta3 and BMP7 is superior in stimulating chondrocyte redifferentiation in both hypoxia and normoxia compared to single treatments. Sci. Rep. 2018, 8, 10251. [CrossRef] [PubMed]

225. Ito, A.; Aoyama, T.; Iijima, H.; Tajino, J.; Nagai, M.; Yamaguchi, S.; Zhang, X.; Kuroki, H. Culture temperature affects redifferentiation and cartilaginous extracellular matrix formation in dedifferentiated human chondrocytes. J. Orthop. Res. 2015, 33, 633-639. [CrossRef] [PubMed]

226. Jakob, M.; Demarteau, O.; Schafer, D.; Hintermann, B.; Dick, W.; Heberer, M.; Martin, I. Specific growth factors during the expansion and redifferentiation of adult human articular chondrocytes enhance chondrogenesis and cartilaginous tissue formation in vitro. J. Cell Biochem. 2001, 81, 368-377. [CrossRef]

227. Jeyakumar, V.; Niculescu-Morzsa, E.; Bauer, C.; Lacza, Z.; Nehrer, S. Redifferentiation of Articular Chondrocytes by Hyperacute Serum and Platelet Rich Plasma in Collagen Type I Hydrogels. Int. J. Mol. Sci. 2019, 20, 316. [CrossRef]

228. Jimenez, G.; López-Ruiz, E.; Kwiatkowski, W.; Montañez, E.; Arrebola, F.; Carrillo, E.; Gray, P.C.; Belmonte, J.C.I.; Choe, S.; Peran, M.; et al. Activin A/BMP2 chimera AB235 drives efficient redifferentiation of long term cultured autologous chondrocytes. Sci. Rep. 2015, 5, 16400. [CrossRef]

229. Kaps, C.; Bramlage, C.; Smolian, H.; Haisch, A.; Burmester, G.-R.; Sittinger, M.; Gross, G. Bone morphogenetic proteins promote cartilage differentiation and protect engineered artificial cartilage from fibroblast invasion and destruction. Arthritis Rheum. 2002, 46, 149-162. [CrossRef]

230. Kawanishi, M.; Oura, A.; Furukawa, K.; Fukubayashi, T.; Nakamura, K.; Tateishi, T.; Ushida, T. Redifferentiation of Dedifferentiated Bovine Articular Chondrocytes Enhanced by Cyclic Hydrostatic Pressure Under a Gas-Controlled System. Tissue Eng. 2007, 13, 957-964. [CrossRef]

231. Kean, T.J.; Dennis, J.E. Synoviocyte derived-extracellular matrix enhances human articular chondrocyte proliferation and maintains re-differentiation capacity at both low and atmospheric oxygen tensions. PLoS ONE 2015, $10, \mathrm{e} 0129961$.

232. Ko, K.-W.; Choi, B.; Park, S.; Arai, Y.; Choi, W.C.; Lee, J.-M.; Bae, H.; Han, I.-B.; Lee, S.-H. Down-Regulation of Transglutaminase 2 Stimulates Redifferentiation of Dedifferentiated Chondrocytes through Enhancing Glucose Metabolism. Int. J. Mol. Sci. 2017, 18, 2359. [CrossRef] 
233. Koh, S.; Purser, M.; Wysk, R.; Piedrahita, J.A. Improved Chondrogenic Potential and Proteomic Phenotype of Porcine Chondrocytes Grown in Optimized Culture Conditions. Cell Reprogramm. 2017, 19, 232-244. [CrossRef]

234. Kumar, D.; Lassar, A.B. The Transcriptional Activity of Sox9 in Chondrocytes Is Regulated by RhoA Signaling and Actin Polymerization. Mol. Cell Biol. 2009, 29, 4262-4273. [CrossRef]

235. Lee, D.K.; Choi, K.B.; Oh, I.S.; Song, S.U.; Hwang, S.; Lim, C.L.; Hyun, J.P.; Lee, H.Y.; Chi, G.F.; Yi, Y.; et al. Continuous transforming growth factor beta1 secretion by cell-mediated gene therapy maintains chondrocyte redifferentiation. Tissue Eng. 2005, 11, 310-318. [CrossRef] [PubMed]

236. Mandl, E.W.; van der Veen, S.W.; Verhaar, J.A.; van Osch, G.J. Serum-free medium supplemented with high-concentration FGF2 for cell expansion culture of human ear chondrocytes promotes redifferentiation capacity. Tissue Eng. 2002, 8, 573-580. [CrossRef] [PubMed]

237. Markway, B.D.; Cho, H.; Johnstone, B. Hypoxia promotes redifferentiation and suppresses markers of hypertrophy and degeneration in both healthy and osteoarthritic chondrocytes. Arthritis Res. Ther. 2013, 15, R92. [CrossRef] [PubMed]

238. Meretoja, V.; Dahlin, R.L.; Kasper, F.K.; Mikos, A.G. Enhanced chondrogenesis in co-cultures with articular chondrocytes and mesenchymal stem cells. Biomaterials 2012, 33, 6362-6369. [CrossRef] [PubMed]

239. Meretoja, V.V.; Dahlin, R.L.; Wright, S.; Kasper, F.K.; Mikos, A.G. Articular Chondrocyte Redifferentiation in 3D Co-cultures with Mesenchymal Stem Cells. Tissue Eng. Part C Methods 2014, 20, 514-523. [CrossRef]

240. Öztürk, E.; Despot-Slade, E.; Pichler, M.; Zenobi-Wong, M. RhoA activation and nuclearization marks loss of chondrocyte phenotype in crosstalk with Wnt pathway. Exp. Cell Res. 2017, 360, 113-124. [CrossRef]

241. Perrier-Groult, E.; Pasdeloup, M.; Malbouyres, M.; Galéra, P.; Mallein-Gerin, F. Control of Collagen Production in Mouse Chondrocytes by Using a Combination of Bone Morphogenetic Protein-2 and Small Interfering RNA Targeting Col1a1 for Hydrogel-Based Tissue-Engineered Cartilage. Tissue Eng. Part C Methods 2013, 19, 652-664. [CrossRef]

242. Rakic, R.; Bourdon, B.; Hervieu, M.; Branly, T.; Legendre, F.; Saulnier, N.; Audigié, F.; Maddens, S.; Demoor, M.; Galera, P. RNA Interference and BMP-2 Stimulation Allows Equine Chondrocytes Redifferentiation in 3D-Hypoxia Cell Culture Model: Application for Matrix-Induced Autologous Chondrocyte Implantation. Int. J. Mol. Sci. 2017, 18, 1842. [CrossRef]

243. Rikkers, M.; Levato, R.; Malda, J.; Vonk, L.A. Importance of Timing of Platelet Lysate-Supplementation in Expanding or Redifferentiating Human Chondrocytes for Chondrogenesis. Front. Bioeng. Biotechnol. 2020, 8, 804. [CrossRef]

244. Sung, L.-Y.; Chiu, H.-Y.; Chen, H.-C.; Chen, Y.-L.; Chuang, C.-K.; Hu, Y.-C. Baculovirus-Mediated Growth Factor Expression in Dedifferentiated Chondrocytes Accelerates Redifferentiation: Effects of Combinational Transduction. Tissue Eng. Part A 2009, 15, 1353-1362. [CrossRef] [PubMed]

245. van der Windt, A.E.; Jahr, H.; Farrell, E.; Verhaar, J.A.; Weinans, H.; van Osch, G.J. Calcineurin inhibitors promote chondrogenic marker expression of dedifferentiated human adult chondrocytes via stimulation of endogenous TGFbeta1 production. Tissue Eng. Part A 2010, 16, 1-10. [CrossRef] [PubMed]

246. Van Osch, G.J.; van der Veen, S.W.; Verwoerd-Verhoef, H.L. In vitro redifferentiation of culture-expanded rabbit and human auricular chondrocytes for cartilage reconstruction. Plast Recons. Surg. 2001, 107, 433-440. [CrossRef] [PubMed]

247. Von Bomhard, A.; Faust, J.; Elsaesser, A.F.; Schwarz, S.; Pippich, K.; Rotter, N. Impact of expansion and redifferentiation under hypothermia on chondrogenic capacity of cultured human septal chondrocytes. J. Tissue Eng. 2017, 8, 2041731417732655. [CrossRef]

248. Wang, X.; Xue, Y.; Ye, W.; Pang, J.; Liu, Z.; Cao, Y.; Zheng, Y.; Ding, D. The MEK-ERK1/2 signaling pathway regulates hyaline cartilage formation and the redifferentiation of dedifferentiated chondrocytes in vitro. Am. J. Transl. Res. 2018, 10, 3068-3085.

249. Yao, Y.; Zhang, F.; Pang, P.X.; Su, K.; Zhou, R.; Wang, Y.; Wang, D.A. In vitro study of chondrocyte redifferentiation with lentiviral vector-mediated transgenic TGF-beta3 and shRNA suppressing type I collagen in three-dimensional culture. J. Tissue Eng. Regen. Med. 2011, 5, e219-e227. [CrossRef]

250. Yao, Y.; Zhang, T.; Chen, H.; Zheng, S.; Chen, Y.; Zhang, S. Enhanced chondrogenesis in a coculture system with genetically manipulated dedifferentiated chondrocytes and ATDC5 cells. Biotechnol. Bioeng. 2020, 117, 3173-3181. [CrossRef]

251. Zhang, F.; Yao, Y.; Su, K.; Pang, P.X.; Zhou, R.; Wang, Y.; Wang, D.A. Redifferentiation of dedifferentiated chondrocytes by adenoviral vector-mediated TGF-beta3 and collagen-1 silencing shRNA in 3D culture. Ann. Biomed. Eng. 2011, 39, 3042-3054. [CrossRef]

252. Bernstein, P.; Dong, M.; Corbeil, D.; Gelinsky, M.; Günther, K.-P.; Fickert, S. Pellet culture elicits superior chondrogenic redifferentiation than alginate-based systems. Biotechnol. Prog. 2009, 25, 1146-1152. [CrossRef]

253. Öztürk, E.; Stauber, T.; Levinson, C.; Cavalli, E.; Arlov, Øystein; Zenobi-Wong, M. Tyrosinase-crosslinked, tissue adhesive and biomimetic alginate sulfate hydrogels for cartilage repair. Biomed. Mater. 2020, 15, 045019. [CrossRef]

254. Tew, S.R.; Hardingham, T.E. Regulation of SOX9 mRNA in Human Articular Chondrocytes Involving p38 MAPK Activation and mRNA Stabilization. J. Biol. Chem. 2006, 281, 39471-39479. [CrossRef]

255. de Crombrugghe, B.; Lefebvre, V.; Behringer, R.R.; Bi, W.; Murakami, S.; Huang, W. Transcriptional mechanisms of chondrocyte differentiation. Matrix Biol. 2000, 19, 389-394. [CrossRef]

256. Öztürk, E.; Øystein, A.; Aksel, S.; Li, L.; Ornitz, D.M.; Skjåk-BraeK, G.; Zenobi-Wong, M.; Skjåk-Bræk, G. Sulfated Hydrogel Matrices Direct Mitogenicity and Maintenance of Chondrocyte Phenotype through Activation of FGF Signaling. Adv. Funct. Mater. 2016, 26, 3649-3662. [CrossRef] 
257. Kim, Y.H.; Lee, J.W. Targeting of focal adhesion kinase by small interfering RNAs reduces chondrocyte redifferentiation capacity in alginate beads culture with type II collagen. J. Cell. Physiol. 2009, 218, 623-630. [CrossRef]

258. Paige, K.T.; Cima, L.G.; Yaremchuk, M.J.; Vacanti, J.P.; Vacanti, C.A. Injectable Cartilage. Plast. Reconstr. Surg. 1995, 96, 1390-1398. [CrossRef]

259. Dobratz, E.J.; Kim, S.W.; Voglewede, A.; Park, S.S. Injectable cartilage: Using alginate and human chondrocytes. Arch. Facial Plast. Surg. 2009, 11, 40-47. [CrossRef]

260. Park, D.-J.; Park, S.-Y.; Bong, J.-P.; Hong, K.-S. Cartilage Generation Using Alginate-Encapsulated Autogenous Chondrocytes in Rabbits. Ann. Otol. Rhinol. Laryngol. 2000, 109, 1157-1161. [CrossRef]

261. Fragonas, E.; Valente, M.; Pozzi-Mucelli, M.; Toffanin, R.; Rizzo, R.; Silvestri, F.; Vittur, F. Articular cartilage repair in rabbits by using suspensions of allogenic chondrocytes in alginate. Biomaterials 2000, 21, 795-801. [CrossRef]

262. Dhollander, A.A.; Verdonk, P.C.; Lambrecht, S.; Verdonk, R.; Elewaut, D.; Verbruggen, G.; Almqvist, K.F. Midterm results of the treatment of cartilage defects in the knee using alginate beads containing human mature allogenic chondrocytes. Am. J. Sports Med. 2012, 40, 75-82. [CrossRef]

263. Martinčič, D.; Mekač, J.; Drobnič, M. Survival Rates of Various Autologous Chondrocyte Grafts and Concomitant Procedures. A Prospective Single-Center Study over 18 Years. Cell Transplant. 2019, 28, 1439-1444. [CrossRef]

264. Cho, S.H.; Lim, S.M.; Han, D.K.; Yuk, S.H.; Im, G.I.; Lee, J.H. Time-Dependent Alginate/Polyvinyl Alcohol Hydrogels as Injectable Cell Carriers. J. Biomater. Sci. Polym. Ed. 2009, 20, 863-876. [CrossRef]

265. Yoon, D.M.; Hawkins, E.C.; Francke-Carroll, S.; Fisher, J.P. Effect of construct properties on encapsulated chondrocyte expression of insulin-like growth factor-1. Biomaterials 2007, 28, 299-306. [CrossRef]

266. Loeser, R.F.; Todd, M.D.; Seely, B.L. Prolonged treatment of human osteoarthritic chondrocytes with insulin-like growth factor-I stimulates proteoglycan synthesis but not proteoglycan matrix accumulation in alginate cultures. J. Rheumatol. 2003, 30, 1565-1570.

267. Chubinskaya, S.; Hakimiyan, A.; Pacione, C.; Yanke, A.; Rappoport, L.; Aigner, T.; Rueger, D.; Loeser, R. Synergistic effect of IGF-1 and OP-1 on matrix formation by normal and OA chondrocytes cultured in alginate beads. Osteoarthr. Cartil. 2007, 15, 421-430. [CrossRef]

268. Loeser, R.F.; Chubinskaya, S.; Pacione, C.; Im, H.-J. Basic fibroblast growth factor inhibits the anabolic activity of insulin-like growth factor 1 and osteogenic protein 1 in adult human articular chondrocytes. Arthritis Rheum. 2005, 52, 3910-3917. [CrossRef]

269. Wang, J.; Elewaut, D.; Veys, E.M.; Verbruggen, G. Insulin-like growth factor 1-induced interleukin-1 receptor II overrides the activity of interleukin-1 and controls the homeostasis of the extracellular matrix of cartilage. Arthritis Rheum. 2003, 48, 1281-1291. [CrossRef]

270. Jenniskens, Y.; Koevoet, W.; de Bart, A.; Weinans, H.; Jahr, H.; Verhaar, J.; DeGroot, J.; van Osch, G. Biochemical and functional modulation of the cartilage collagen network by IGF1, TGF $\beta 2$ and FGF2. Osteoarthr. Cartil. 2006, 14, 1136-1146. [CrossRef]

271. Chubinskaya, S.; Hakimiyan, A.A.; Rappoport, L.; Yanke, A.; Rueger, D.C.; Cole, B.J. Response of Human Chondrocytes Prepared for Autologous Implantation to Growth Factors. J. Knee Surg. 2008, 21, 192-199. [CrossRef]

272. Flechtenmacher, J.; Huch, K.; Thonar, E.J.-M.A.; Mollenhauer, J.A.; Bs, S.R.D.; Schmid, T.M.; Puhl, W.; Sampath, T.K.; Aydelotte, M.B.; Kuettner, K.E. Recombinant human osteogenic protein 1 is a potent stimulator of the synthesis of cartilage proteoglycans and collagens by human articular chondrocytes. Arthritis Rheum. 1996, 39, 1896-1904. [CrossRef]

273. Masuda, K.; Pfister, B.; Sah, R.; Thonar, E.-M. Osteogenic protein-1 promotes the formation of tissue-engineered cartilage using the alginate-recovered-chondrocyte method. Osteoarthr. Cartil. 2006, 14, 384-391. [CrossRef]

274. Stöve, J.; Schneider-Wald, B.; Scharf, H.-P.; Schwarz, M. Bone morphogenetic protein 7 (bmp-7) stimulates Proteoglycan synthesis in human osteoarthritic chondrocytes in vitro. Biomed. Pharmacother. 2006, 60, 639-643. [CrossRef] [PubMed]

275. Madry, H.; Orth, P.; Kaul, G.; Zurakowski, D.; Menger, M.D.; Kohn, D.; Cucchiarini, M. Acceleration of articular cartilage repair by combined gene transfer of human insulin-like growth factor I and fibroblast growth factor-2 in vivo. Arch. Orthop. Trauma Surg. 2010, 130, 1311-1322. [CrossRef] [PubMed]

276. Starkman, B.G.; Cravero, J.D.; DelCarlo, M.; Loeser, R.F. IGF-I stimulation of proteoglycan synthesis by chondrocytes requires activation of the PI 3-kinase pathway but not ERK MAPK. Biochem. J. 2005, 389, 723-729. [CrossRef]

277. Madry, H.; Emkey, G.; Zurakowski, D.; Trippel, S.B. Overexpression of human fibroblast growth factor 2 stimulates cell proliferation in an ex vivo model of articular chondrocyte transplantation. J. Gene Med. 2004, 6, 238-245. [CrossRef]

278. Cucchiarini, M.; Madry, H.; Ma, C.; Thurn, T.; Zurakowski, D.; Menger, M.D.; Kohn, D.; Trippel, S.B.; Terwilliger, E.F. Improved tissue repair in articular cartilage defects in vivo by rAAV-mediated overexpression of human fibroblast growth factor 2 . Mol. Ther. 2005, 12, 229-238. [CrossRef]

279. Kunitomo, T.; Takahashi, K.A.; Arai, Y.; Sakao, K.; Honjo, K.; Saito, M.; Inoue, A.; Tonomura, H.; Morihara, T.; Mazda, O.; et al. Influence of extracellular matrix on the expression of inflammatory cytokines, proteases, and apoptosis-related genes induced by hydrostatic pressure in three-dimensionally cultured chondrocytes. J. Orthop. Sci. 2009, 14, 776-783. [CrossRef]

280. Sah, R.L.-Y.; Kim, Y.-J.; Doong, J.-Y.H.; Grodzinsky, A.J.; Plass, A.H.K.; Sandy, J.D. Biosynthetic response of cartilage explants to dynamic compression. J. Orthop. Res. 1989, 7, 619-636. [CrossRef]

281. Grogan, S.P.; Sovani, S.; Pauli, C.; Chen, J.; Hartmann, A.; ColwellJr., C.W.; Lotz, M.K.; D’Lima, D.D. Effects of Perfusion and Dynamic Loading on Human Neocartilage Formation in Alginate Hydrogels. Tissue Eng. Part A 2012, 18, 1784-1792. [CrossRef]

282. Jeon, J.; Schrobback, K.; Hutmacher, D.; Klein, T. Dynamic compression improves biosynthesis of human zonal chondrocytes from osteoarthritis patients. Osteoarthr. Cartil. 2012, 20, 906-915. [CrossRef] 
283. Xu, X.; Urban, J.P.; Tirlapur, U.; Wu, M.-H.; Cui, Z.; Cui, Z. Influence of perfusion on metabolism and matrix production by bovine articular chondrocytes in hydrogel scaffolds. Biotechnol. Bioeng. 2006, 93, 1103-1111. [CrossRef]

284. Yu, L.; Ferlin, K.M.; Nguyen, B.-N.B.; Fisher, J.P. Tubular perfusion system for chondrocyte culture and superficial zone protein expression. J. Biomed. Mater. Res. Part A 2015, 103, 1864-1874. [CrossRef] [PubMed]

285. Sharma, G.; Saxena, R.; Mishra, P. Differential effects of cyclic and static pressure on biochemical and morphological properties of chondrocytes from articular cartilage. Clin. Biomech. 2007, 22, 248-255. [CrossRef] [PubMed]

286. Grimshaw, M.; Mason, R. Bovine articular chondrocyte function in vitro depends upon oxygen tension. Osteoarthr. Cartil. 2000, 8 , 386-392. [CrossRef]

287. Schneider, N.; Lejeune, J.-P.; Deby, C.; Deby-Dupont, G.; Serteyn, D. Viability of equine articular chondrocytes in alginate beads exposed to different oxygen tensions. Veter. J. 2004, 168, 167-173. [CrossRef] [PubMed]

288. Murphy, C.L.; Polak, J.M. Control of human articular chondrocyte differentiation by reduced oxygen tension. J. Cell. Physiol. 2004, 199, 451-459. [CrossRef] [PubMed]

289. Twu, C.-W.; Reuther, M.S.; Briggs, K.K.; Sah, R.L.; Masuda, K.; Watson, D. Effect of Oxygen Tension on Tissue-Engineered Human Nasal Septal Chondrocytes. Allergy Rhinol. 2014, 5, 125-131. [CrossRef]

290. Xu, X.; Urban, J.; Tirlapur, U.; Cui, Z. Osmolarity effects on bovine articular chondrocytes during three-dimensional culture in alginate beads. Osteoarthr. Cartil. 2010, 18, 433-439. [CrossRef]

291. Negoro, K.; Kobayashi, S.; Takeno, K.; Uchida, K.; Baba, H. Effect of osmolarity on glycosaminoglycan production and cell metabolism of articular chondrocyte under three-dimensional culture system. Clin. Exp. Rheumatol. 2008, $26,534-541$.

292. Hopewell, B.; Urban, J.P.G. Adaptation of articular chondrocytes to changes in osmolality. Biorheology 2003, 40, 73-77.

293. Zhang, Z.-J.; Huckle, J.; A Francomano, C.; Spencer, R.G. The effects of pulsed low-intensity ultrasound on chondrocyte viability, proliferation, gene expression and matrix production. Ultrasound Med. Biol. 2003, 29, 1645-1651. [CrossRef]

294. Choi, B.H.; Woo, J.-I.; Min, B.-H.; Park, S.R. Low-intensity ultrasound stimulates the viability and matrix gene expression of human articular chondrocytes in alginate bead culture. J. Biomed. Mater. Res. Part A 2006, 79, 858-864. [CrossRef] [PubMed]

295. Grimshaw, M.; Mason, R. Modulation of bovine articular chondrocyte gene expression in vitro by oxygen tension. Osteoarthr. Cartil. 2001, 9, 357-364. [CrossRef] [PubMed]

296. Maroudas, A.; Evans, H. A Study of Ionic Equilibria in Cartilage. Connect. Tissue Res. 1972, 1, 69-77. [CrossRef]

297. Urban, J.P.G.; Hall, A.C.; Gehl, K.A. Regulation of matrix synthesis rates by the ionic and osmotic environment of articular chondrocytes. J. Cell. Physiol. 1993, 154, 262-270. [CrossRef]

298. Sanchez, C.; Mathy-Hartert, M.; A Deberg, M.; Ficheux, H.; Reginster, J.Y.L.; Henrotin, Y.E. Effects of rhein on human articular chondrocytes in alginate beads. Biochem. Pharmacol. 2003, 65, 377-388. [CrossRef]

299. Kim, G.; Okumura, M.; Bosnakovski, D.; Ishiguro, T.; Park, C.-H.; Kadosawa, T.; Fujinaga, T. Effects of ascorbic acid on proliferation and biological properties of bovine chondrocytes in alginate beads. Jpn. J. Vet.-Res. 2003, 51, 83-94.

300. Cheng, X.; Li, K.; Xu, S.; Li, P.; Yan, Y.; Wang, G.; Berman, Z.; Guo, R.; Liang, J.; Traore, S.; et al. Applying chlorogenic acid in an alginate scaffold of chondrocytes can improve the repair of damaged articular cartilage. PLoS ONE 2018, 13, e0195326. [CrossRef]

301. Verdonk, P.; Wang, J.; Groeneboer, S.; Broddelez, C.; Elewaut, D.; Veys, E.; Verbruggen, G. Cyclodextrin polysulphates repress IL-1 and promote the accumulation of chondrocyte extracellular matrix. Osteoarthr. Cartil. 2005, 13, 887-895. [CrossRef]

302. Wang, P.; Zhang, F.; He, Q.; Wang, J.; Shiu, H.T.; Shu, Y.; Tsang, W.P.; Liang, S.; Zhao, K.; Wan, C. Flavonoid Compound Icariin Activates Hypoxia Inducible Factor- $1 \alpha$ in Chondrocytes and Promotes Articular Cartilage Repair. PLoS ONE 2016, 11, e0148372. [CrossRef]

303. Karpie, J.C.; Chu, C.R. Lidocaine Exhibits Dose- and Time-Dependent Cytotoxic Effects on Bovine Articular Chondrocytes in Vitro. Am. J. Sports Med. 2007, 35, 1622-1627. [CrossRef]

304. Takeno, K.; Kobayashi, S.; Miyazaki, T.; Shimada, S.; Kubota, M.; Meir, A.; Urban, J.; Baba, H. Lidocaine cytotoxicity to the zygapophysial joints in rabbits: Changes in cell viability and proteoglycan metabolism in vitro. Spine 2009, 34, E945-E951. [CrossRef] [PubMed]

305. Seshadri, V.; Coyle, C.H.; Chu, C.R. Lidocaine Potentiates the Chondrotoxicity of Methylprednisolone. Arthrosc. J. Arthrosc. Relat. Surg. 2009, 25, 337-347. [CrossRef] [PubMed]

306. Yuan, L.; Niu, C.; Lin, S.; Chan, Y.; Yang, C.; Chen, W.; Ueng, S. Additive effects of hyperbaric oxygen and platelet-derived growth factor-BB in chondrocyte transplantation via up-regulation expression of platelet-derived growth factor-beta receptor-Beneficial for the subchondral bone remodeling and calcification. Bone 2009, 44, 1439-1446. [CrossRef]

307. Kaul, G.; Cucchiarini, M.; Arntzen, D.; Zurakowski, D.; Menger, M.D.; Kohn, D.; Trippel, S.B.; Madry, H. Local stimulation of articular cartilage repair by transplantation of encapsulated chondrocytes overexpressing human fibroblast growth factor 2 (FGF-2) in vivo. J. Gene Med. 2005, 8, 100-111. [CrossRef] [PubMed]

308. Orth, P.; Kaul, G.; Cucchiarini, M.; Zurakowski, D.; Menger, M.D.; Kohn, D.; Madry, H. Transplanted articular chondrocytes co-overexpressing IGF-I and FGF-2 stimulate cartilage repair in vivo. Knee Surg. Sports Traumatol. Arthrosc. 2011, 19, $2119-2130$. [CrossRef] [PubMed]

309. Duval, E.; Bauge, C.; Andriamanalijaona, R.; Bénateau, H.; Leclercq, S.; Dutoit, S.; Poulain, L.; Galéra, P.; Boumédiene, K. Molecular mechanism of hypoxia-induced chondrogenesis and its application in in vivo cartilage tissue engineering. Biomaterials 2012, 33, 6042-6051. [CrossRef] [PubMed] 
310. Steinert, A.; Weber, M.; Dimmler, A.; Julius, C.; Schütze, N.; Nöth, U.; Cramer, H.; Eulert, J.; Zimmermann, U.; Hendrich, C. Chondrogenic differentiation of mesenchymal progenitor cells encapsulated in ultrahigh-viscosity alginate. J. Orthop. Res. 2003, 21, 1090-1097. [CrossRef]

311. Fernandes, A.M.; Herlofsen, S.R.; Karlsen, T.A.; Küchler, A.M.; Fløisand, Y.; Brinchmann, J.E. Similar Properties of Chondrocytes from Osteoarthritis Joints and Mesenchymal Stem Cells from Healthy Donors for Tissue Engineering of Articular Cartilage. PLoS ONE 2013, 8, e62994. [CrossRef]

312. Mata, M.; Milian, L.; Oliver, M.; Zurriaga, J.; Sancho-Tello, M.; DE Llano, J.J.M.; Carda, C. In Vivo Articular Cartilage Regeneration Using Human Dental Pulp Stem Cells Cultured in an Alginate Scaffold: A Preliminary Study. Stem Cells Int. 2017, 2017, 8309256. [CrossRef]

313. Hontani, K.; Onodera, T.; Terashima, M.; Momma, D.; Matsuoka, M.; Baba, R.; Joutoku, Z.; Matsubara, S.; Homan, K.; Hishimura, R.; et al. Chondrogenic differentiation of mouse induced pluripotent stem cells using the three-dimensional culture with ultra-purified alginate gel. J. Biomed. Mater. Res. Part A 2019, 107, 1086-1093. [CrossRef]

314. Ko, J.-Y.; Kim, K.-I.; Park, S.; Im, G.-I. In vitro chondrogenesis and in vivo repair of osteochondral defect with human induced pluripotent stem cells. Biomaterials 2014, 35, 3571-3581. [CrossRef] [PubMed]

315. Wei, Y.; Zeng, W.; Wan, R.; Wang, J.; Zhou, Q.; Qiu, S.; Singh, S. Chondrogenic differentiation of induced pluripotent stem cells from osteoarthritic chondrocytes in alginate matrix. Eur. Cells Mater. 2012, 23, 1-12. [CrossRef] [PubMed]

316. Nguyen, D.; Hägg, D.A.; Forsman, A.; Ekholm, J.; Nimkingratana, P.; Brantsing, C.; Kalogeropoulos, T.; Zaunz, S.; Concaro, S.; Brittberg, M.; et al. Cartilage Tissue Engineering by the 3D Bioprinting of iPS Cells in a Nanocellulose/Alginate Bioink. Sci. Rep. 2017, 7, 1-10. [CrossRef] [PubMed]

317. Kurth, T.; Hedbom, E.; Shintani, N.; Sugimoto, M.; Chen, F.; Haspl, M.; Martinovic, S.; Hunziker, E. Chondrogenic potential of human synovial mesenchymal stem cells in alginate. Osteoarthr. Cartil. 2007, 15, 1178-1189. [CrossRef] [PubMed]

318. Ichinose, S.; Yamagata, K.; Sekiya, I.; Muneta, T.; Tagami, M. Detailed Examination Of Cartilage Formation And Endochondral Ossification Using Human Mesenchymal Stem Cells. Clin. Exp. Pharmacol. Physiol. 2005, 32, 561-570. [CrossRef]

319. Xu, J.; Wang, W.; Ludeman, M.; Cheng, K.; Hayami, T.; Lotz, J.C.; Kapila, S. Chondrogenic Differentiation of Human Mesenchymal Stem Cells in Three-Dimensional Alginate Gels. Tissue Eng. Part A 2008, 14, 667-680. [CrossRef]

320. Endres, M.; Wenda, N.; Woehlecke, H.; Neumann, K.; Ringe, J.; Erggelet, C.; Lerche, D.; Kaps, C. Microencapsulation and chondrogenic differentiation of human mesenchymal progenitor cells from subchondral bone marrow in Ca-alginate for cell injection. Acta Biomater. 2010, 6, 436-444. [CrossRef]

321. Bosnakovski, D.; Mizuno, M.; Kim, G.; Takagi, S.; Okumura, M.; Fujinaga, T. Chondrogenic differentiation of bovine bone marrow mesenchymal stem cells (MSCs) in different hydrogels: Influence of collagen type II extracellular matrix on MSC chondrogenesis. Biotechnol. Bioeng. 2006, 93, 1152-1163. [CrossRef]

322. Herlofsen, S.R.; Küchler, A.M.; Melvik, J.E.; Brinchmann, J.E. Chondrogenic Differentiation of Human Bone Marrow-Derived Mesenchymal Stem Cells in Self-Gelling Alginate Discs Reveals Novel Chondrogenic Signature Gene Clusters. Tissue Eng. Part A 2011, 17, 1003-1013. [CrossRef]

323. Lee, H.J.; Choi, B.H.; Min, B.-H.; Son, Y.S.; Park, S.R. Low-intensity Ultrasound Stimulation Enhances Chondrogenic Differentiation in Alginate Culture of Mesenchymal Stem Cells. Artif. Organs 2006, 30, 707-715. [CrossRef]

324. Samuel, S.; Ahmad, R.E.; Ramasamy, T.S.; Karunanithi, P.; Naveen, S.V.; Kamarul, T. Platelet-rich concentrate in serum-free medium enhances cartilage-specific extracellular matrix synthesis and reduces chondrocyte hypertrophy of human mesenchymal stromal cells encapsulated in alginate. Platelets 2017, 30, 66-74. [CrossRef] [PubMed]

325. Beigi, M.-H.; Atefi, A.; Ghanaei, H.-R.; Labbaf, S.; Ejeian, F.; Nasr-Esfahani, M.-H. Activated platelet-rich plasma improves cartilage regeneration using adipose stem cells encapsulated in a 3D alginate scaffold. J. Tissue Eng. Regen. Med. 2018, 12, 1327-1338. [CrossRef] [PubMed]

326. Gao, X.; Gao, L.; Groth, T.; Liu, T.; He, D.; Wang, M.; Gong, F.; Chu, J.; Zhao, M. Fabrication and properties of an injectable sodium alginate/PRP composite hydrogel as a potential cell carrier for cartilage repair. J. Biomed. Mater. Res. Part A 2019, 107, $2076-2087$. [CrossRef] [PubMed]

327. He, P.; Fu, J.; Wang, D.-A. Murine pluripotent stem cells derived scaffold-free cartilage grafts from a micro-cavitary hydrogel platform. Acta Biomater. 2016, 35, 87-97. [CrossRef] [PubMed]

328. Lin, Y.; Luo, E.; Chen, X.; Liu, L.; Qiao, J.; Yan, Z.; Li, Z.; Tang, W.; Zheng, X.; Tian, W. Molecular and cellular characterization during chondrogenic differentiation of adipose tissue-derived stromal cells in vitro and cartilage formation in vivo. J. Cell Mol. Med. 2005, 9, 929-939. [CrossRef] [PubMed]

329. Jin, X.-B.; Sun, Y.-S.; Zhang, K.; Wang, J.; Ju, X.-D.; Lou, S.-Q. Neocartilage formation from predifferentiated human adipose derived stem cells in vivo. Acta Pharmacol. Sin. 2007, 28, 663-671. [CrossRef]

330. Liu, L.; Chen, R.-L.; Tian, W.-D.; Yan, Z.-B.; Chen, X.-Z.; Li, S.-W.; Wang, T. A study on the chondrogenesis of the compound of alginate gelatin and bone marrow stromal cells in vivo. Hua Xi Kou Qiang Yi Xue Za Zhi 2005, 23, 60-62.

331. Ye, R.; Hao, J.; Song, J.; Zhao, Z.; Fang, S.; Wang, Y.; Li, J. Microenvironment Is Involved in Cellular Response to Hydrostatic Pressures During Chondrogenesis of Mesenchymal Stem Cells. J. Cell. Biochem. 2014, 115, 1089-1096. [CrossRef]

332. Guo, T.; Yu, L.; Lim, C.G.; Goodley, A.S.; Xiao, X.; Placone, J.K.; Ferlin, K.M.; Nguyen, B.-N.B.; Hsieh, A.H.; Fisher, J.P. Effect of Dynamic Culture and Periodic Compression on Human Mesenchymal Stem Cell Proliferation and Chondrogenesis. Ann. Biomed. Eng. 2015, 44, 2103-2113. [CrossRef] 
333. Li, Y.; Zhou, J.; Yang, X.; Jiang, Y.; Gui, J. Intermittent hydrostatic pressure maintains and enhances the chondrogenic differentiation of cartilage progenitor cells cultivated in alginate beads. Dev. Growth Differ. 2016, 58, 180-193. [CrossRef]

334. Daly, A.; Sathy, B.N.; Kelly, D.J. Engineering large cartilage tissues using dynamic bioreactor culture at defined oxygen conditions. J. Tissue Eng. 2018, 9, 2041731417753718. [CrossRef] [PubMed]

335. Sathy, B.N.; Daly, A.; Gonzalez-Fernandez, T.; Olvera, D.; Cunniffe, G.; McCarthy, H.O.; Dunne, N.; Jeon, O.; Alsberg, E.; Donahue, T.L.H.; et al. Hypoxia mimicking hydrogels to regulate the fate of transplanted stem cells. Acta Biomater. 2019, 88, 314-324. [CrossRef] [PubMed]

336. Gharravi, A.M. Encapsulated explant in novel low shear perfusion bioreactor improve cell isolation, expansion and colony forming unit. Cell Tissue Bank. 2019, 20, 25-34. [CrossRef] [PubMed]

337. Tseng, S.-J.; Huang, S.-T.; Wu, C.-C.; Cheng, C.-H.; Lin, J.-C. Studies of proliferation and chondrogenic differentiation of rat adipose stem cells using an anti-oxidative polyurethane scaffold combined with cyclic compression culture. Mater. Sci. Eng. C 2020, 112, 110964. [CrossRef] [PubMed]

338. Gamez, C.; Schneider-Wald, B.; Schuette, A.; Mack, M.; Hauk, L.; Khan, A.U.M.; Gretz, N.; Stoffel, M.; Bieback, K.; Schwarz, M.L. Bioreactor for mobilization of mesenchymal stem/stromal cells into scaffolds under mechanical stimulation: Preliminary results. PLoS ONE 2020, 15, e0227553. [CrossRef] [PubMed]

339. Cucchiarini, M. Human gene therapy: Novel approaches to improve the current gene delivery systems. Discov. Med. 2016, 21, 495-506. [PubMed]

340. Venkatesan, J.K.; Falentin-Daudré, C.; Leroux, A.; Migonney, V.; Cucchiarini, M. Controlled release of gene therapy constructs from solid scaffolds for therapeutic applications in orthopedics. Discov. Med. 2018, 25, 195-203.

341. Díaz-Rodríguez, P.; Rey-Rico, A.; Madry, H.; Landin, M.; Cucchiarini, M. Effective genetic modification and differentiation of hMSCs upon controlled release of rAAV vectors using alginate/poloxamer composite systems. Int. J. Pharm. 2015, 496, 614-626. [CrossRef]

342. Maihofer, J.; Madry, H.; Rey-Rico, A.; Venkatesan, J.K.; Goebel, L.; Schmitt, G.; Speicher-Mentges, S.; Cai, X.; Meng, W.; Zurakowski, D.; et al. Hydrogel-guided, rAAV-mediated IGF-I overexpression enables long-term cartilage repair and protection against perifocal osteoarthritis in a large-animal full-thickness chondral defect model at one year in vivo. Adv. Mater. 2021, 33, e2008451. [CrossRef]

343. Raisin, S.; Belamie, E.; Morille, M. Non-viral gene activated matrices for mesenchymal stem cells based tissue engineering of bone and cartilage. Biomaterials 2016, 104, 223-237. [CrossRef]

344. Gonzalez-Fernandez, T.; Tierney, E.G.; Cunniffe, G.M.; O’Brien, F.J.; Kelly, D.J. Gene Delivery of TGF-beta3 and BMP2 in an MSC-laden alginate hydrogel for articular cartilage and endochondral bone tissue engineering. Tissue Eng. Part A 2016, 22, 776-787. [CrossRef]

345. Neumann, A.J.; Schroeder, J.; Alini, M.; Archer, C.W.; Stoddart, M.J. Enhanced Adenovirus Transduction of hMSCs Using 3D Hydrogel Cell Carriers. Mol. Biotechnol. 2013, 53, 207-216. [CrossRef] [PubMed]

346. Moncada-Saucedo, N.K.; Marino-Martínez, I.A.; Lara-Arias, J.; Romero-Díaz, V.J.; Camacho, A.; Valdés-Franco, J.A.; Pérez-Silos, V.; García-Ruiz, A.; Lin, H.; Tuan, R.S.; et al. A Bioactive Cartilage Graft of IGF1-Transduced Adipose Mesenchymal Stem Cells Embedded in an Alginate/Bovine Cartilage Matrix Tridimensional Scaffold. Stem Cells Int. 2019, 2019, 9792369. [CrossRef] [PubMed]

347. Zhu, S.; Zhang, T.; Sun, C.; Yu, A.; Qi, B.; Cheng, H. Bone marrow mesenchymal stem cells combined with calcium alginate gel modified by hTGF-beta1 for the construction of tissue-engineered cartilage in three-dimensional conditions. Exp. Ther. Med. 2013, 5, 95-101. [CrossRef] [PubMed]

348. Ying, J.; Wang, P.; Zhang, S.; Xu, T.; Zhang, L.; Dong, R.; Xu, S.; Tong, P.; Wu, C.; Jin, H. Transforming growth factor-beta1 promotes articular cartilage repair through canonical Smad and Hippo pathways in bone mesenchymal stem cells. Life Sci. 2018, 192, 84-90. [CrossRef]

349. Shen, J.; Shi, D.; Dong, L.; Zhang, Z.; Li, X.; Chen, M. Fabrication of polydopamine nanoparticles knotted alginate scaffolds and their properties. J. Biomed. Mater. Res. Part A 2018, 106, 3255-3266. [CrossRef] [PubMed]

350. Stagnaro, P.; Schizzi, I.; Utzeri, R.; Marsano, E.; Castellano, M. Alginate-polymethacrylate hybrid hydrogels for potential osteochondral tissue regeneration. Carbohydr. Polym. 2018, 185, 56-62. [CrossRef]

351. Trachsel, L.; Johnbosco, C.; Lang, T.; Benetti, E.M.; Zenobi-Wong, M. Double-Network Hydrogels Including Enzymatically Crosslinked Poly-(2-alkyl-2-oxazoline)s for 3D Bioprinting of Cartilage-Engineering Constructs. Biomacromolecules 2019, 20, 4502-4511. [CrossRef]

352. Yang, X.; Lu, Z.; Wu, H.; Li, W.; Zheng, L.; Zhao, J. Collagen-alginate as bioink for three-dimensional (3D) cell printing based cartilage tissue engineering. Mater. Sci. Eng. C 2018, 83, 195-201. [CrossRef]

353. Gossla, E.; Bernhardt, A.; Tonndorf, R.; Aibibu, D.; Cherif, C.; Gelinsky, M. Anisotropic Chitosan Scaffolds Generated by Electrostatic Flocking Combined with Alginate Hydrogel Support Chondrogenic Differentiation. Int. J. Mol. Sci. 2021, $22,9341$. [CrossRef]

354. Ghahramanpoor, M.K.; Najafabadi, S.A.H.; Abdouss, M.; Bagheri, F.; Eslaminejad, M.B. A hydrophobically-modified alginate gel system: Utility in the repair of articular cartilage defects. J. Mater. Sci. Mater. Electron. 2011, 22, 2365-2375. [CrossRef] [PubMed]

355. Sun, J.-Y.; Zhao, X.; Illeperuma, W.R.K.; Chaudhuri, O.; Oh, K.H.; Mooney, D.J.; Vlassak, J.J.; Suo, Z. Highly stretchable and tough hydrogels. Nature 2012, 489, 133-136. [CrossRef] [PubMed] 
356. Marsich, E.; Borgogna, M.; Donati, I.; Mozetic, P.; Strand, B.L.; Salvador, S.G.; Vittur, F.; Paoletti, S. Alginate/lactose-modified chitosan hydrogels: A bioactive biomaterial for chondrocyte encapsulation. J. Biomed. Mater. Res. Part A 2008, 84A, 364-376. [CrossRef] [PubMed]

357. Ma, F.; Ge, Y.; Liu, N.; Pang, X.; Shen, X.; Tang, B. In situ fabrication of a composite hydrogel with tunable mechanical properties for cartilage tissue engineering. J. Mater. Chem. B 2019, 7, 2463-2473. [CrossRef]

358. Al-Sabah, A.; Burnell, S.; Simoes, I.N.; Jessop, Z.; Badiei, N.; Blain, E.; Whitaker, I.S. Structural and mechanical characterization of crosslinked and sterilised nanocellulose-based hydrogels for cartilage tissue engineering. Carbohydr. Polym. 2019, 212, $242-251$. [CrossRef]

359. Cohen, D.L.; Lo, W.; Tsavaris, A.; Peng, D.; Lipson, H.; Bonassar, L.J. Increased Mixing Improves Hydrogel Homogeneity and Quality of Three-Dimensional Printed Constructs. Tissue Eng. Part C Methods 2011, 17, 239-248. [CrossRef]

360. Park, H.; Lee, H.J.; An, H.; Lee, K.Y. Alginate hydrogels modified with low molecular weight hyaluronate for cartilage regeneration. Carbohydr. Polym. 2017, 162, 100-107. [CrossRef]

361. Chu, Y.; Huang, L.; Hao, W.; Zhao, T.; Zhao, H.; Yang, W.; Xie, X.; Qian, L.; Chen, Y.; Dai, J. Long-term stability, high strength, and 3D printable alginate hydrogel for cartilage tissue engineering application. Biomed. Mater. 2021, 16, 064102. [CrossRef]

362. Guo, P.; Yuan, Y.; Chi, F. Biomimetic alginate/polyacrylamide porous scaffold supports human mesenchymal stem cell proliferation and chondrogenesis. Mater. Sci. Eng. C 2014, 42, 622-628. [CrossRef]

363. Müller, W.; Neufurth, M.; Wang, S.; Tolba, E.; Schröder, H.; Wang, X. Morphogenetically active scaffold for osteochondral repair (polyphosphate/alginate/N,O-carboxymethyl chitosan). Eur. Cells Mater. 2016, 31, 174-190. [CrossRef]

364. Scholten, P.M.; Ng, K.W.; Joh, K.; Serino, L.P.; Warren, R.F.; Torzilli, P.A.; Maher, S.A. A semi-degradable composite scaffold for articular cartilage defects. J. Biomed. Mater. Res. Part A 2011, 97A, 8-15. [CrossRef] [PubMed]

365. Liao, I.C.; Moutos, F.T.; Estes, B.T.; Zhao, X.; Guilak, F. Composite three-dimensional woven scaffolds with interpenetrating network hydrogels to create functional synthetic articular cartilage. Adv. Funct. Mater. 2013, 23, 5833-5839. [CrossRef] [PubMed]

366. Lee, C.S.; Gleghorn, J.; Choi, N.; Cabodi, M.; Stroock, A.; Bonassar, L.J. Integration of layered chondrocyte-seeded alginate hydrogel scaffolds. Biomaterials 2007, 28, 2987-2993. [CrossRef] [PubMed]

367. You, F.; Wu, X.; Zhu, N.; Lei, M.; Eames, B.F.; Chen, X. 3D Printing of Porous Cell-Laden Hydrogel Constructs for Potential Applications in Cartilage Tissue Engineering. ACS Biomater. Sci. Eng. 2016, 2, 1200-1210. [CrossRef] [PubMed]

368. Tomkoria, S.; Masuda, K.; Mao, J. Nanomechanical properties of alginate-recovered chondrocyte matrices for cartilage regeneration. Proc. Inst. Mech. Eng. Part H J. Eng. Med. 2007, 221, 467-473. [CrossRef]

369. Schipani, R.; Scheurer, S.; Florentin, R.; Critchley, S.E.; Kelly, D.J. Reinforcing interpenetrating network hydrogels with 3D printed polymer networks to engineer cartilage mimetic composites. Biofabrication 2020, 12, 035011. [CrossRef]

370. De Melo, B.A.G.; Jodat, Y.A.; Mehrotra, S.; Calabrese, M.; Kamperman, T.; Mandal, B.B.; Santana, M.H.A.; Alsberg, E.; Leijten, J.; Shin, S.R. 3D Printed Cartilage-Like Tissue Constructs with Spatially Controlled Mechanical Properties. Adv. Funct. Mater. 2019, 29, 1906330. [CrossRef]

371. Chu, J.; Zeng, S.; Gao, L.; Groth, T.; Li, Z.; Kong, J.; Zhao, M.; Li, L. Poly (L-Lactic Acid) Porous Scaffold-Supported Alginate Hydrogel with Improved Mechanical Properties and Biocompatibility. Int. J. Artif. Organs 2016, 39, 435-443. [CrossRef]

372. Cao, Y.; Cheng, P.; Sang, S.; Xiang, C.; An, Y.; Wei, X.; Shen, Z.; Zhang, Y.; Li, P. Mesenchymal stem cells loaded on 3D-printed gradient poly(epsilon-caprolactone)/methacrylated alginate composite scaffolds for cartilage tissue engineering. Regen. Biomater. 2021, 8, rbab019. [CrossRef] [PubMed]

373. Awad, H.; Wickham, M.Q.; Leddy, H.A.; Gimble, J.M.; Guilak, F. Chondrogenic differentiation of adipose-derived adult stem cells in agarose, alginate, and gelatin scaffolds. Biomaterials 2004, 25, 3211-3222. [CrossRef]

374. Wong, M.; Siegrist, M.; Gaschen, V.; Park, Y.; Graber, W.; Studer, D. Collagen Fibrillogenesis by Chondrocytes in Alginate. Tissue Eng. 2002, 8, 979-987. [CrossRef] [PubMed]

375. Heywood, H.K.; Sembi, P.K.; Lee, D.A.; Bader, D.L. Cellular utilization determines viability and matrix distribution profiles in chondrocyte-seeded alginate constructs. Tissue Eng. 2004, 10, 1467-1479. [CrossRef] [PubMed]

376. Bastiaansen-Jenniskens, Y.; Koevoet, W.; de Bart, A.; van der Linden, J.; Zuurmond, A.; Weinans, H.; Verhaar, J.; van Osch, G.; DeGroot, J. Contribution of collagen network features to functional properties of engineered cartilage. Osteoarthr. Cartil. 2008, 16, 359-366. [CrossRef]

377. Wan, L.Q.; Jiang, J.; Miller, D.E.; Guo, X.E.; Mow, V.C.; Lu, H.H. Matrix Deposition Modulates the Viscoelastic Shear Properties of Hydrogel-Based Cartilage Grafts. Tissue Eng. Part A 2011, 17, 1111-1122. [CrossRef] [PubMed]

378. Chen, W.; Wenliang, C.; Peng, M.; Xie, B.; Zhang, L.; Tang, X. Autologous nasal chondrocytes delivered by injectable hydrogel for in vivo articular cartilage regeneration. Cell Tissue Bank. 2018, 19, 35-46. [CrossRef] [PubMed]

379. Möller, T.; Amoroso, M.; Hägg, D.; Brantsing, C.; Rotter, N.; Apelgren, P.; Lindahl, A.; Kölby, L.; Gatenholm, P. In Vivo Chondrogenesis in 3D Bioprinted Human Cell-laden Hydrogel Constructs. Plast. Reconstr. Surg.-Glob. Open 2017, 5, e1227. [CrossRef] [PubMed]

380. Gross, J.; Highberger, J.H.; Schmitt, F.O. Collagen structures considered as states of aggregation of a kinetic unit. The tropocollagen particle. Proc. Natl. Acad. Sci. USA 1954, 40, 679-688. [CrossRef]

381. Kielty, C.M.; Hulmes, D.J.; Schor, S.L.; Grant, M.E. Embryonic chick cartilage collagens. Differences in the low-Mr species present in sternal cartilage and tibiotarsal articular cartilage. FEBS Lett. 1984, 169, 179-184. [CrossRef] 
382. Kobayashi, K.; Ito, T.; Hoshino, T. Electron Microscopic Demonstration of Acid-Labile, 4D-Staggered Intermolecular Association of Collagen Formed In Vitro. Collagen Relat. Res. 1985, 5, 253-260. [CrossRef]

383. Lilja, S.; Barrach, H.J. An electron microscopical study of the influence of different glycosaminoglycans on the fibrillogenesis of collagen type I and II in vitro. Virchows. Arch. A Pathol. Anat. Histol. 1981, 390, 325-338. [CrossRef]

384. Pérez-Tamayo, K. The Occurrence and Significance of SLS Crystallites In Vivo. Connect. Tissue Res. 1972, 1, 55-60. [CrossRef]

385. Wibowo, S.; Velazquez, G.; Savant, V.; Torres, J.A. Surimi wash water treatment for protein recovery: Effect of chitosan-alginate complex concentration and treatment time on protein adsorption. Bioresour. Technol. 2005, 96, 665-671. [CrossRef]

386. Woo, E.; Park, H.; Lee, K.Y. Shear Reversible Cell/Microsphere Aggregate as an Injectable for Tissue Regeneration. Macromol. Biosci. 2014, 14, 740-748. [CrossRef] [PubMed]

387. Han, L.-H.; Lai, J.H.; Yu, S.; Yang, F. Dynamic tissue engineering scaffolds with stimuli-responsive macroporosity formation. Biomaterials 2013, 34, 4251-4258. [CrossRef] [PubMed]

388. Ruoslahti, E. Rgd And Other Recognition Sequences For Integrins. Annu. Rev. Cell Dev. Biol. 1996, 12, 697-715. [CrossRef]

389. Chastain, S.R.; Kundu, A.K.; Dhar, S.; Calvert, J.W.; Putnam, A.J. Adhesion of mesenchymal stem cells to polymer scaffolds occurs via distinct ECM ligands and controls their osteogenic differentiation. J. Biomed. Mater. Res. Part A 2006, 78A, 73-85. [CrossRef]

390. Enomoto-Iwamoto, M.; Iwamoto, M.; Nakashima, K.; Mukudai, Y.; Boettiger, D.; Pacifici, M.; Kurisu, K.; Suzuki, F. Involvement of alpha5beta1 integrin in matrix interactions and proliferation of chondrocytes. J. Bone Miner Res. 1997, 12, 1124-1132. [CrossRef]

391. Lópiz-Morales, Y.; Abarrategi, A.; Ramos, V.; Moreno-Vicente, C.; López-Durán, L.; López-Lacomba, J.L.; Marco, F. In vivo comparison of the effects of rhBMP-2 and rhBMP-4 in osteochondral tissue regeneration. Eur. Cells Mater. 2010, 20, 367-378. [CrossRef]

392. Mo, X.-T.; Guo, S.-C.; Xie, H.-Q.; Deng, L.; Zhi, W.; Xiang, Z.; Li, X.-Q.; Yang, Z.-M. Variations in the ratios of co-cultured mesenchymal stem cells and chondrocytes regulate the expression of cartilaginous and osseous phenotype in alginate constructs. Bone 2009, 45, 42-51. [CrossRef]

393. Pleumeekers, M.M.; Nimeskern, L.; Koevoet, J.L.M.; Karperien, M.; Stok, K.S.; Van Osch, G.J.V.M. Trophic effects of adiposetissue-derived and bone-marrow-derived mesenchymal stem cells enhance cartilage generation by chondrocytes in co-culture. PLOS ONE 2018, 13, e0190744. [CrossRef]

394. Zhang, F.; Su, K.; Fang, Y.; Sandhya, S.; Wang, D.-A. A mixed co-culture of mesenchymal stem cells and transgenic chondrocytes in alginate hydrogel for cartilage tissue engineering. J. Tissue Eng. Regen. Med. 2015, 9, 77-84. [CrossRef] [PubMed]

395. Jang, C.H.; Koo, Y.; Kim, G. ASC/chondrocyte-laden alginate hydrogel/PCL hybrid scaffold fabricated using 3D printing for auricle regeneration. Carbohydr. Polym. 2020, 248, 116776. [CrossRef]

396. Markstedt, K.; Mantas, A.; Tournier, I.; Ávila, H.M.; Hägg, D.; Gatenholm, P. 3D Bioprinting Human Chondrocytes with Nanocellulose-Alginate Bioink for Cartilage Tissue Engineering Applications. Biomacromolecules 2015, 16, 1489-1496. [CrossRef]

397. Bakarich, S.E.; Gorkin, R., III; in het Panhuis, M.; Spinks, G.M. Three-dimensional printing fiber reinforced hydrogel composites. ACS Appl. Mater. Interfaces 2014, 6, 15998-16006. [CrossRef]

398. Schwarz, S.; Kuth, S.; Distler, T.; Gögele, C.; Stölzel, K.; Detsch, R.; Boccaccini, A.R.; Schulze-Tanzil, G. 3D printing and characterization of human nasoseptal chondrocytes laden dual crosslinked oxidized alginate-gelatin hydrogels for cartilage repair approaches. Mater. Sci. Eng. C 2020, 116, 111189. [CrossRef] [PubMed]

399. Zhou, Y.; Yue, Z.; Chen, Z.; Wallace, G. 3D Coaxial Printing Tough and Elastic Hydrogels for Tissue Engineering Using a Catechol Functionalized Ink System. Adv. Heal. Mater. 2020, 9, e2001342. [CrossRef] [PubMed]

400. Jessop, Z.M.; Al-Sabah, A.; Gao, N.; Kyle, S.; Thomas, B.; Badiei, N.; Hawkins, K.; Whitaker, I.S. Printability of pulp derived crystal, fibril and blend nanocellulose-alginate bioinks for extrusion 3D bioprinting. Biofabrication 2019, 11, 045006. [CrossRef]

401. Kundu, J.; Shim, J.H.; Jang, J.; Kim, S.W.; Cho, D.W. An additive manufacturing-based PCL-alginate-chondrocyte bioprinted scaffold for cartilage tissue engineering. J. Tissue Eng. Regen. Med. 2015, 9, 1286-1297. [CrossRef]

402. Park, J.Y.; Choi, Y.J.; Shim, J.H.; Park, J.H.; Cho, D.W. Development of a 3D cell printed structure as an alternative to autologs cartilage for auricular reconstruction. J. Biomed. Mater. Res. B Appl. Biomater. 2017, 105, 1016-1028. [CrossRef] 